\title{
Challenges and strategies for generating therapeutic patient-specific hemangioblasts and hematopoietic stem cells from human pluripotent stem cells
}

\author{
ANN PETERS ${ }^{1}$, PAUL W. BURRIDGE¹, MARINA V. PRYZHKOVA ${ }^{1}$, MICHAL A. LEVINE¹, \\ TEA SOON PARK ${ }^{1,3}$, CHRISTOPHER ROXBURY $^{1}$, XUAN YUAN ${ }^{1}$, BRUNO PÉAULT ${ }^{3}$ \\ and ELIAS T. ZAMBIDIS*,1,2 \\ ${ }^{1}$ Institute for Cell Engineering, Stem Cell Program, Johns Hopkins University School of Medicine, \\ ${ }^{2}$ Division of Pediatric Oncology, Sidney Kimmel Comprehensive Cancer Center at Johns Hopkins Univer- \\ sity, Baltimore MD and ${ }^{3}$ Stem Cell Research Center and Department of Pediatrics, University of Pittsburgh \\ School of Medicine, Pittsburgh, PA, USA
}

\begin{abstract}
Recent characterization of hemangioblasts differentiated from human embryonic stem cells (hESC) has further confirmed evidence from murine, zebrafish and avian experimental systems that hematopoietic and endothelial lineages arise from a common progenitor. Such progenitors may provide a valuable resource for delineating the initial developmental steps of human hemato-endotheliogenesis, which is a process normally difficult to study due to the very limited accessibility of early human embryonic/fetal tissues. Moreover, efficient hemangioblast and hematopoietic stem cell (HSC) generation from patient-specific pluripotent stem cells has enormous potential for regenerative medicine, since it could lead to strategies for treating a multitude of hematologic and vascular disorders. However, significant scientific challenges remain in achieving these goals, and the generation of transplantable hemangioblasts and HSC derived from hESC currently remains elusive. Our previous work has suggested that the failure to derive engraftable $\mathrm{HSC}$ from $\mathrm{hESC}$ is due to the fact that current methodologies for differentiating hESC produce hematopoietic progenitors developmentally similar to those found in the human yolk sac, and are therefore too immature to provide adult-type hematopoietic reconstitution. Herein, we outline the nature of this challenge and propose targeted strategies for generating engraftable human pluripotent stem cell-derived HSC from primitive hemangioblasts using a developmental approach. We also focus on methods by which reprogrammed somatic cells could be used to derive autologous pluripotent stem cells, which in turn could provide unlimited sources of patient-specific hemangioblasts and HSC.
\end{abstract}

KEY WORDS: human embryonic stem cell, induced pluripotent stem cell, hematopoieisis, iPSC, HSC

Prospects for generating patient-specific hemangioblasts and HSC from human pluripotent stem cells

Since Thomson and colleagues first isolated pluripotent human embryonic stem cells (hESC) from the inner cell mass of preimplantation blastocyst embryos (Thomson etal., 1998), hESC have been envisioned as an unlimited source for generating transplantable cell lineages. Furthermore, because hESC can readily be manipulated and genetically altered using transgenesis
(Ma etal., 2003; Vallier etal., 2004) or homologous recombination (Zwaka and Thomson, 2003; Urbach et al., 2004), these cell lines have great potential for use in novel cellular therapies for a number of genetic and degenerative diseases, including hematologic disorders. Despite increased efforts to match allogeneic

\footnotetext{
Abbreviations used in this paper: $\mathrm{hEB}$, human embryoid body; hESC, human embryonic stem cell; HSC, hematopoietic stem cell; iPSC, induced pluripotent stem cell; PG, parthenogenesis; SCNT, somatic cell nuclear transplant; YS,
} yolk sac. 
transplant donors and recipients, many patients fail to receive immunocompatible bone marrow, cord blood, or peripheral blood stem cell transplants required for effective, long-term treatment of their hematologic diseases (Grewal et al., 2003). As a result, the survival rate for most potentially transplantable hematologic disorders remains low (Davies et al., 1995), and new sources of transplantable, immunocompatible hematopoietic stem cells (HSC) are needed. A long sought-after goal has been to generate large amounts of autologous, genetically corrected HSC to treat severe hematologic diseases such as sickle cell anemia, thalassemia, and leukemia. The recent scientific achievement of geneticallyinduced pluripotency of somatic cells (e.g., from skin fibroblasts) has introduced the possibility that HSC generated from patientspecific induced pluripotent stem cells (iPSC) will eventually meet this challenge. The proof of principle for this approach was recently demonstrated in a murine model of sickle cell hemoglobinopathy where iPSC were generated from sickle hemoglobinaffected murine fibroblasts (Hanna et al., 2007). These studies showed that genetically-corrected iPSC could generate normal, autologous transplantable HSC that could cure sickle cell anemia in a murine model. Additionally, the efficient generation of unlimited supplies of hemangioblasts with endothelial progenitor capacity from hESC and iPSC may also lead to novel strategies for treating myocardial infarction, stroke, retinal blindness, and a multitude of other vascular disorders.

The realization of these goals poses great scientific challenges, since the generation of transplantable hemangioblasts and HSC from hESC or iPSC has not yet been efficiently described. We previously showed that hESC differentiation produces blood cells similar to those found in the human yolk sac (YS), which are too immature to provide adult-type hematopoietic reconstitution. A sophisticated developmental biologic approach is necessary for elucidating effective strategies that can differentiate hESC/iPSC into either early mesoderm or YS-like hemangioblastic progenitors that can develop into transplantable HSC that are found in the adult bone marrow.

In this review, we outline the challenges and opportunities for deriving hemangioblasts and HSC from human pluripotent stem cells, and propose developmental strategies that could be employed to generate hESC-derived HSC from primitive hemangioblasts ex vivo. We also summarize the methods by which reprogrammed somatic cells can produce patient-specific pluripotent stem cells, which subsequently could provide unlimited sources of autologous, transplantable hemangioblasts and HSC.

\section{Embryonic hemangioblasts sequentially develop into the adult hematopoietic system}

Classic anatomic observations of an intimate association between emerging embryonic blood cells and vascular endothelium led to the hypothesis that they share a common developmental precursor, termed the hemangioblast (Sabin, 1920; Murray, 1932). In mice and humans, two waves of hematopoieses form the blood system: primitive (yolk sac; YS) and definitive (adulttype) hematopoieses. Hematopoietic progenitors derived from YS blood islands are limited in their developmental capacity, and produce primarily primitive erythroblasts. In contrast, the second, definitive wave of hematopoiesis generates long-term engrafting lympho-hematopoietic HSC, which arise de novo from presumptive hemangioblasts (via hemogenic endothelium) in the aortagonad-mesonephros (AGM) region of the embryo (Medvinsky and Dzierzak, 1996; Cumano et al., 2001). These HSC migrate from the AGM to fetal liver and bone marrow niches around birth in the mouse (Blazsek et al., 2000), and at the end of the first trimester in the human fetus (Charbord et al., 1996), where they sustain the adult's lifetime blood generation.

In the mouse, hemangioblast formation is initiated by the ingress of pluripotent epiblast cells through the primitive streak resulting in fate-committed mesodermal cells (Lawson et al., 1991; Huber et al., 2004). These mesodermal populations within the primitive streak can be divided into four subpopulations/tissue compartments (axial, paraxial, lateral plate, and extraembryonic). The axial mesoderm, which consists of cells that ingress closest to the most anterior region of the primitive streak, forms the notochord. The paraxial mesoderm, which is created by cells that emerge in the anterior third region of the primitive streak, generates the somites, and subsequently the vertebral column and skeletal muscles. The lateral plate mesoderm, which is composed of cells in the middle of the primitive streak, forms the circulatory system, gut wall, and the aorta-gonad mesonephros (AGM), which is the major source of adult, definitive-type HSC. Finally, the extraembryonic mesoderm, which is produced from cells that progress through the most posterior region of the primitive streak, develops into (primitive) blood cells and the vasculature of the YS (Fig. $1 \mathrm{~A}, \mathrm{~B})$.

To date, there are only limited studies of early human hematopoietic development, and such studies have suggested, but not confirmed, the existence of a similar bipotential human hemangioblast (Cortes et al., 1999; Tavian et al., 1999a; Tavian et al., 2001; Oberlin et al., 2002). Thus, despite substantial differences between human and mouse development (Tam and Beddington, 1987; Beddington and Robertson, 1998), our understanding of the mechanisms for the emergence of HSC from embryonic hemangioblasts is primarily derived from studies of murine hematopoiesis. The ethical and technical difficulties associated with studying human development have precluded the detailed characterization of a similar hemangioblastic origin of human primitive and definitive hematopoiesis. Additionally, a narrow repertoire of available human hemangioblastic surface markers has further complicated the characterization of these rare progenitors in the human YS or AGM tissues, which is currently available only in limited amounts.

Keller and colleagues originally demonstrated that mouse embryonic stem cells (mESC) differentiated in a manner that recapitulated embryonic hematopoiesis through the emergence of the hemangioblast (Wiles and Keller, 1991; Keller et al., 1993; Vittet et al., 1996). mESC were differentiated into multi-lineage clusters of aggregated cells, called embryoid bodies (EB), which contain elements of endoderm, mesoderm, and ectoderm before maturing into more defined cell populations. If cultured in methylcellulose containing hematopoietic growth factors, or co-cultured on bone marrow OP9 stromal cells (Nakano et al., 1996), single EB cell progenitors differentiated into embryonic hematopoietic progenitors. In particular, hematopoiesis initiated from a hemangioblastic, clonogenic "blast-colony-forming cell" (BL-CFC), which was demonstrated not only during mouse EB (mEB) differentiation (Kabrun et al., 1997; Kennedy et al., 1997; Choi et al., 
1998; Robertson et al., 2000; Lacaud et al., 2002; Fehling et al., 2003), but also in vivo (Huber et al., 2004). This transient, VEGFresponsive progenitor normally arises in YS blood island mesoderm, where it initiates vasculogenesis, as well as primitive and definitive hematopoieses. Recent single-cell time-lapse microscopy imaging studies of mESC-derived mesodermal precursor differentiated on OP9 stromal cells, and their equivalent in vivo counterparts from mouse embryos, have further confirmed the ability of hemangioblasts (or hemogenic endothelial cells) to give rise to blood cells in real time (Eilken et al., 2009; Lancrin et al., 2009). The emergence of this transient progenitor population was shown to be regulated by SCL/Tal1, whereas further maturation into definitive hematopoietic cells depended on Runx1/ AML1 (Lancrin et al., 2009).

\section{Embryo/Definitive}

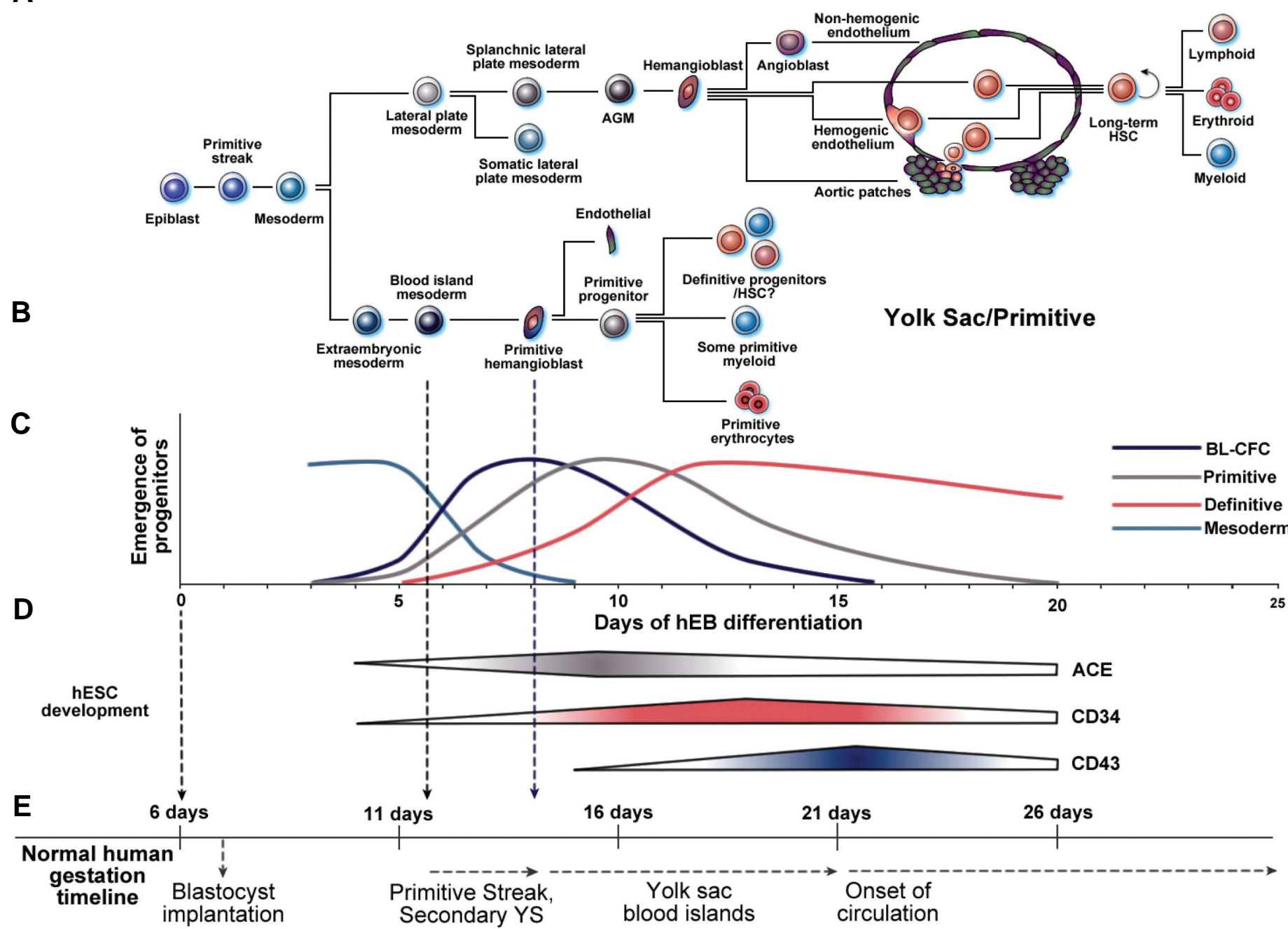

Fig. 1. Comparative schematic of normal human embryonic hematopoiesis and in vitro human embryonic stem cell (hESC) differentiation. (A) Aorta-gonad-mesonephros (AGM) embryonic definitive hematopoiesis originates from the lateral plate mesoderm, and gives rise to adult definitive-type hematopoietic stem cells (HSC) capable of long-term lympho-hematopoietic engraftment in adult recipients. (B) In contrast, primitive yolk sac (YS) hematopoiesis initiates from extra-embryonic mesoderm, and is characterized by the formation of primitive hemangioblasts within YS blood islands that provide ephemeral hematopoiesis for the developing embryo. (C) Human embryoid body (hEB) differentiation recapitulates human YS development and gives rise to mesodermal progenitors, hemangioblasts (BL-CFC), and YS-like primitive and definitive blood cells in two sequential waves. (D) Angiotensin converting enzyme (ACE; CD143), CD34, and CD43 gene expression are upregulated during hemangioblast development, emerging hematopoietic stem cells, and embryonic hematopoietic cells, respectively (Zambidis et al., 2008). (E) Normal human YS development appears to parallel the timeline of our in vitro hEB hematopoietic differentiation system. $h E S C$ lines are derived from the inner cell mass of a $\sim$ day 6 human blastocyst, and are maintained in an undifferentiated state prior to hematopoietic hEB differentiation. During normal gestation, human YS development directly follows formation of the primitive streak, and the extraembryonic secondary YS layers at gestational days 12-13. The formation of primordial YS blood islands first occurs at days 14-16, with subsequent generation of primitive erythro-myelopoietic cell lines starting after 18-20 days. MHE clusters and ACE $B$ L-CFC similarly arise in our system at a corrected gestational timeline of $\sim 12-13$ days $(6 d$ of blastocyst age + days 6-7 of hEB differentiation), which is when the human primitive streak first develops. Subsequently, primitive erythropoiesis arises at a corrected timeline of $~ 14-16$ days (6d of blastocyst age $+8-10$ days of hEB differentiation), which is the milestone for YS blood island generation. Finally, definitive erythro-myelopoiesis arises in our system at a corrected timeline of $>18-20$ days (6d of blastocystage $+12-20$ days of hEB differentiation), when similar events occur in the human YS, prior to the onset of fetal circulation at about 21 days. 
In general, these YS-like, mEB-derived progenitors, however, have had limited engraftment potential when injected into lethallyirradiated murine recipients (Potocnik et al., 1997; Miyagi et al., 2002), although various degrees of maturation into definitive hematopoietic progenitors could be accomplished by culture on AGM stroma (Byrne et al., 2007), or via direct injection into the murine neonatal liver (Egami et al., 2003). These results indicate that murine $Y S$ hemangioblasts can give rise to not only primitive YS hematopoiesis, but may also possess the potential to mature and contribute to the definitive-type HSC population which primarily develops in the AGM. Interestingly, ectopic mEB expression of homeobox, and cell-cycling proto-oncogenes such as Hoxb4, $B c r / A b l, S t a t 5$, and $C d x 4$, can "program" YS-like mEB progenitors into definitive-like HSC capable of long-term engraftment (Perlingeiro etal., 2001; Kyba etal., 2002; Kyba etal., 2003; Wang et al., 2005). Unfortunately, similar experiments utilizing hESC differentiation did not result in long-term engrafting, definitive HSC formation, possibly underscoring fundamentally different developmental potentials between mice and humans (Wang et al., 2005a; Wang et al., 2005).

We, and others, have described various methods for the hematopoietic differentiation of hESC, including the derivation of human embryoid body (hEB) progenitors with hemangioblastic potential (Kaufman et al., 2001; Chadwick et al., 2003; Cerdan et al., 2004; Wang etal., 2004; Vodyanik etal., 2005; Zambidis et al., 2005; Vodyanik et al., 2006; Zambidis et al., 2008). Our group described a hESC model that recapitulates the human YS stages of embryonic hemato-endothelial development (Zambidis et al., 2005) (Fig. 1). Hematopoietic activity was shown to arise in hEB cells from $\mathrm{CD}^{-} 5^{-}$mesodermal-hemato-endothelial (MHE) progenitors that give rise to hematopoietic blast colonies, followed by two sequential YS-like primitive and definitive hematopoietic waves. We also delineated the kinetics of hEB differentiation in serum-free conditions for the emergence of a putative common hemangioblastic progenitor responsible for these two waves. Hematopoietic colony-forming cell (CFC) potential of hEB cells differentiated in serum-free medium with hematopoietic growth factors showed that 6-9 day old hEB vigorously initiated YS-like, primitive and definitive hematopoieses. Primitive foamy macrophages and large nucleated erythroblasts expressing exclusively embryonic and fetal hemoglobins were observed during days 7-12 of hEB differentiation. This was followed by YS-like definitive erythropoiesis (that had limited amounts of adult hemoglobin; Fig. 2), myelopoiesis, and megakaryopoiesis typical of a late YS stage of development at days 12-20 of hEB development. Progressive expression of SCL/TAL1, RUNX1/AML1, GATA1, and $G A T A 2$ (genes known to play roles in the initiation of hematopoiesis from murine hemangioblasts) during this period indicated that this hEB-derived model recapitulated early embryonic hematopoietic development.

Although these detailed kinetic studies of hEB differentiation predicted the emergence of a hemangioblastic progenitor, they did not demonstrate this stem-progenitor in a clonal manner. In contrast to murine experimental systems, the clonal characterization of human hemangioblasts that give rise to such primitive and definitive hematopoieses has been hindered by several obstacles, including 1) inefficient methods for hematopoietic differentiation of hESC, 2) the lack of an accurate prospective hemangioblast surface marker, and 3) the absence of a quantita- tive, robust human BL-CFC assay, that was recently described (Kennedy et al., 2007; Zambidis et al., 2008). Furthermore, although KDR/flk-1 (VEGFR2) is a cell surface marker of populations containing murine hemangioblasts, it appears to be less specific for specifying rare hemangioblasts in human tissues, and is expressed abundantly in a majority of differentiating hEB cells, as well as during normal human embryonic development (Carpenter et al., 2003; Kennedy et al., 2007; Zambidis et al., 2008). The identification of more specific markers for human hemangioblasts, or hemogenic endothelium will greatly facilitate the ultimate experimental goal of efficiently deriving HSC from them.

\section{ACE (CD143) expression marks the emergence of a clonogenic, hESC-derived hemangioblastic progeni- tor of primitive and definitive YS-like hematopoieses}

Using a monoclonal antibody (mAb BB9) specific for the somatic isoform of surface angiotensin-converting enzyme (ACE) CD143), Simmons and colleagues identified a primitive subset of NOD-SCID mouse-engrafting CD34+ HSC in adult bone marrow, mobilized peripheral, and umbilical cord blood. Moreover, in rare 30-day-old human embryonic tissues, ACE (CD143) was shown to mark emergent HSC in the human YS, intra-embryonic subaortic patches of the AGM, and fetal liver (Ramshaw et al.,2001; Jokubaitis et al., 2008). The embryonic pattern of human ACE expression is consistent with a dorsal emigration of $A C E+C D 34$ hemangioblasts from the para-aortic splanchnopleura, and subsequent colonization of the ventral aspect of the dorsal aorta to give rise to CD34+ hemogenic endothelial cells.

Our group extended these studies and used the ACE/CD143 marker to specifically identify hESC-derived clonogenic hemangioblasts that can initiate both primitive and definitive $Y S$ like hematopoieses (Zambidis et al., 2008), similar to that observed in mEB differentiation and murine embryos (Kennedy et al., 1997; Huber et al., 2004). Using a serum-free BL-CFC assay supplemented with BMP4, VEGF, FGF2/heparan sulfate and $\mathrm{TPO}$, single $\mathrm{ACE}{ }^{+} \mathrm{CD} 34^{+/-} \mathrm{hEB}$ cells generated blast colonies containing multilineage endothelial-primitive-definitive hematopoietic progenitors (Fig. 3A). On secondary re-culture assays, these multipotent blast colonies generated YS-like GlyA ${ }^{+} C D 71+C D 45-$ erythroid cells, and endothelium (if re-cultured on stromal-free conditions), or alternatively definitive-type CD45 ${ }^{+}$erythromyeloid cells (if re-cultured on OP9 bone marrow stroma (Fig. 3A)).

Interestingly, our hEB differentiation system appears to recreate hematopoietic events in vitrowhich normally occur during the first weeks of human embryonic development, and that are likely initiated with mesodermal commitment to a YS hemangioblast (Fig. 1). In murine embryos, hemangioblasts first appear in the posterior region of the primitive streak (Huber et al., 2004), and in vitromEB differentiation is generally considered an experimental surrogate for these post-implantation developmental events. Similarly, the developmental kinetics of our hEB-derived mesodermalhemato-endothelial (MHE) clusters, and $\mathrm{ACE}^{+} \mathrm{BL}-\mathrm{CFC}$ mirror the emergence of hemangioblasts that presumably arise following human primitive streak formation at days $12-13$ with a remarkably congruent timeline (FIGURE 1D, E). Similarly, normal YS blood island generation at gestational days 14-16 was recapitulated by 
an hEB-derived wave of primitive hematopoiesis, followed by a definitive wave of erythromyelopoesis, which normally occurs at gestational days 18-20 (prior to the onset of fetal circulation at day 21). These results suggested that our hEB-based differentiation system serves as an in vitro model to study the earliest developmental steps in human hematopoietic genesis.

\section{The renin-angiotensin system may dictate embryonic hemangioblast lineage differentiation}

The discovery that angiotensin converting enzyme (ACE/ CD143) marks primitive embryonic hemangioblasts raised the possibility that the versatile renin-angiotensin system plays a critical role in regulating the earliest stages of human hemato- endothelial differentiation, as it does in avian embryos (Savary et al., 2005). In adults, the renin-angiotensin axis regulates blood pressure and water balance via hormonal secretion of angiotensin II (Ang II) peptide. Ang II is the proteolytic product of a series of enzymatic processes that begin with the cleavage of angiotensinogen by renin to yield the catalytic substrate of the ACE, angiotensin I (Ang I), which is ultimately converted to Ang II (Paul et al., 2006). Renin-angiotensin system signaling is subsequently mediated by angiotensin II type 1 and 2 receptors (AGTR1/AGTR2), which are locally expressed in all important sites of emerging angio-hematopoiesis including the YS, liver, kidney, embryonic aorta, and retinal/choroid regions (Schutz et al., 1996). Notably, while AGTR1 is expressed constitutively from development to adulthood where it functions as a key regulator of

\section{Day 9 hEB PRIMITIVE}

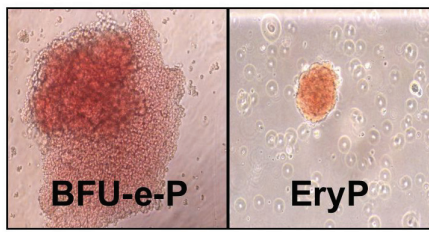

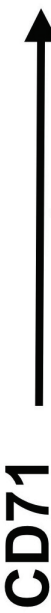

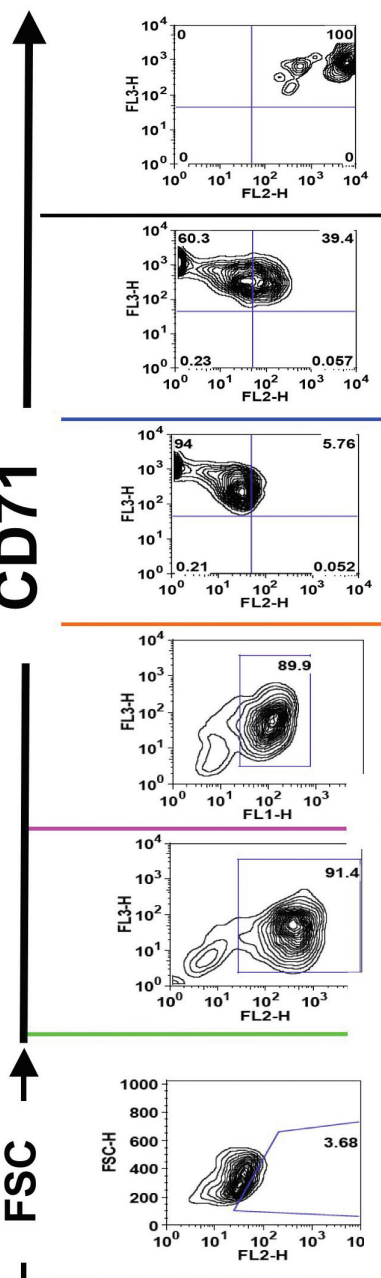

\section{Day 14 hEB DEFINITIVE}
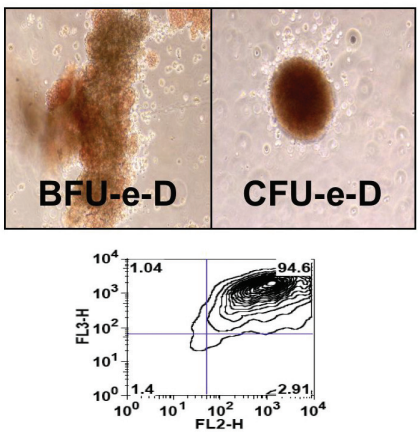
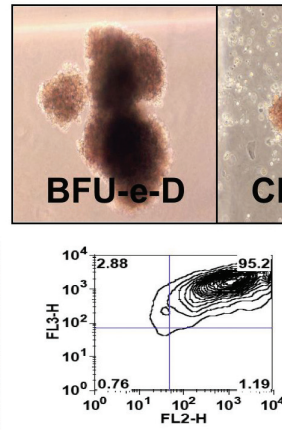

\section{CD34+ CB DEFINITIVE}
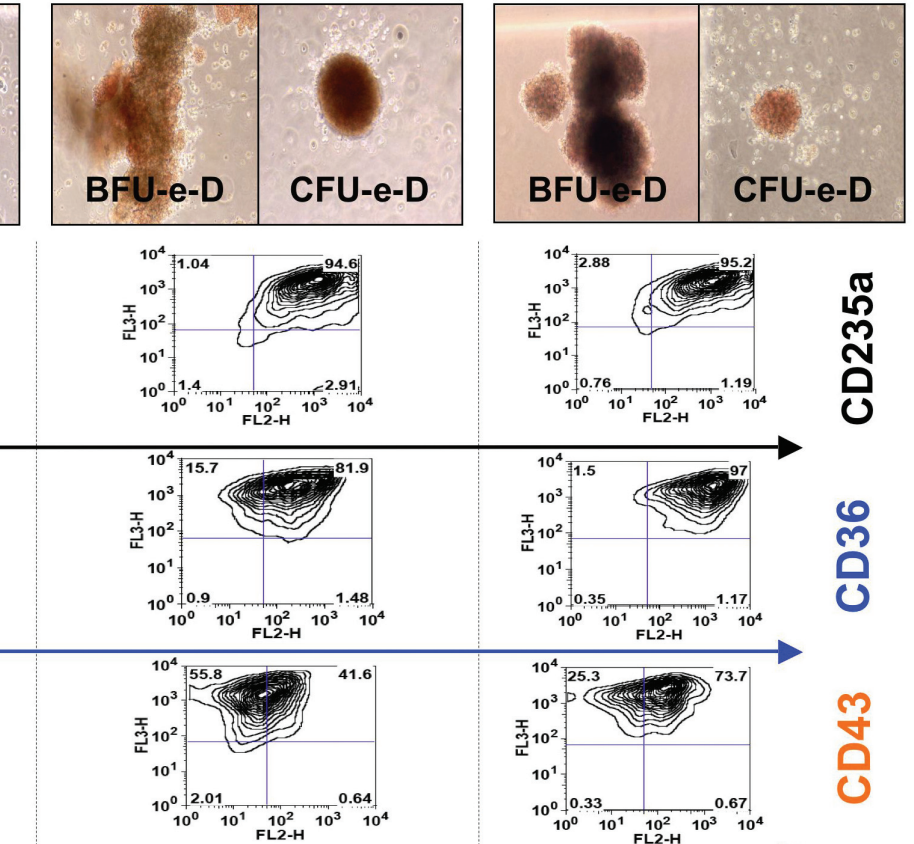

(3)

辞
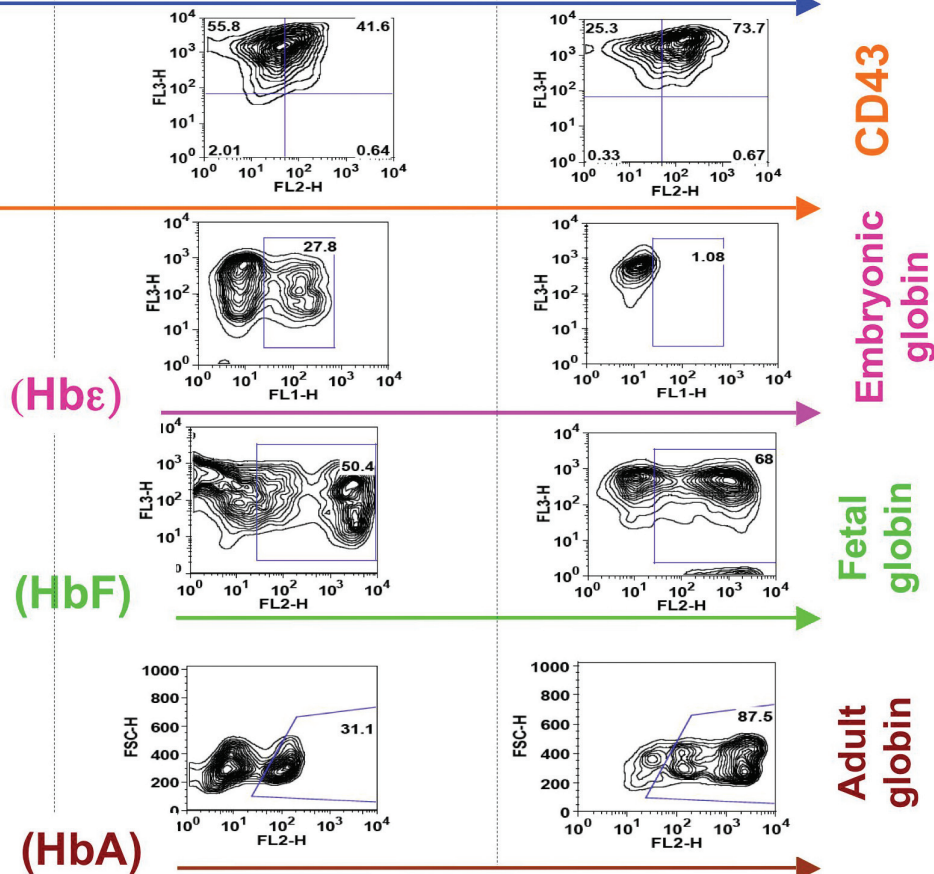

$(\mathrm{HbA})$
Fig. 2. Recapitulation of normal embryonic erythropoietic development using in vitro human embryonic stem cell ( $h E S C$ ) differentiation. Line H1 (WA01) hESC-derived hEB were differentiated into hematopoietic cells using SF culture conditions in the presence of VEGF, BMP4, FGF2, and heparan sulfate (VBF2 as above). Single-cell suspensions from day 9 and day 14 hEBs, as well as CD34+enriched neonatal cord blood (CB) cells (positive control for adult-type definitive colonies) were re-cultured for colony-forming-cell (CFC) potential in methylcellulose medium. Brownish, "Salmon-red" hemoglobinization was observed on primitive erythroid colonies (EryP, BFU-e-P; left column) generated from day 7 to 12 hEBs, while day 12 to 20 hEBs erythroid colonies (EryD, BFU-e-D; middle column) resembled definitive $C D 34+C B$ blood cells (BFU-e-D, CFU-e-D; right column). Surface marker expression by FACS analysis revealed that all types of erythoid CFCs had similar surface expression of CD71 and CD235a (GlycophorinA) erythoid progenitor markers, but CD36, an erytho-myeloid lineage marker, was only moderately expressed in EryP/ BFu-e-D, and the embryonic pan-hematopoietic marker CD43 was mostly absent in EryP/BFUe-P, and only moderately expressed in BFU-e-D/ CFU-e-D. Hemoglobin detection showed high levels of embryonic $\mathrm{Hb}$ and fetal $\mathrm{HbF}$, but little adult HbA in EryP/ BFU-e-P. In contrast, $B F U-e-D / C F U-e-D$ express moderate levels of all hemoglobins, while $C B$ erythroid hemoglobin status is limited mostly to adult $\mathrm{HbA}$ and $\mathrm{HbF}$. Figure adapted from Zambidis et al., 2008, with permission. 
A

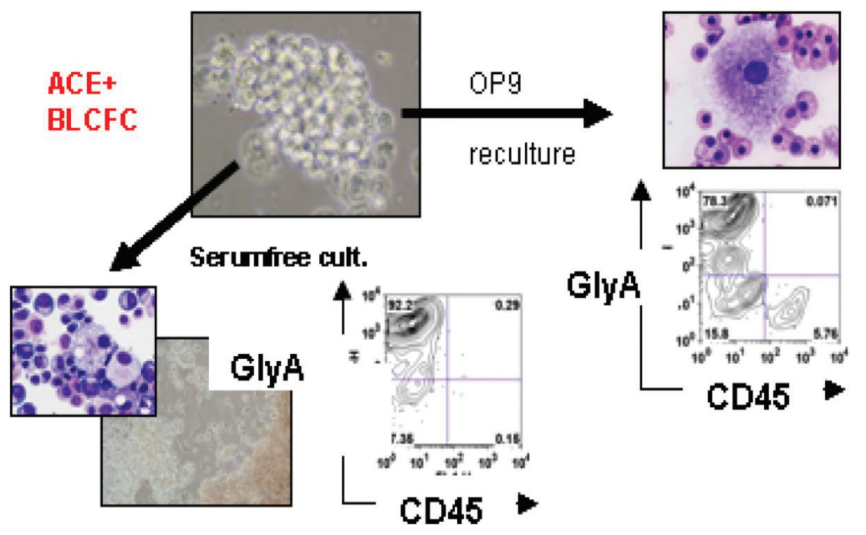

B

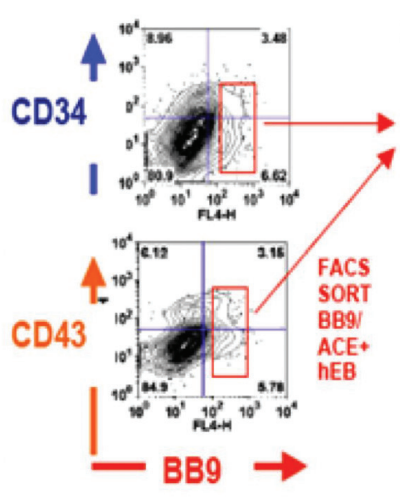

HMSC stromal co-cuture
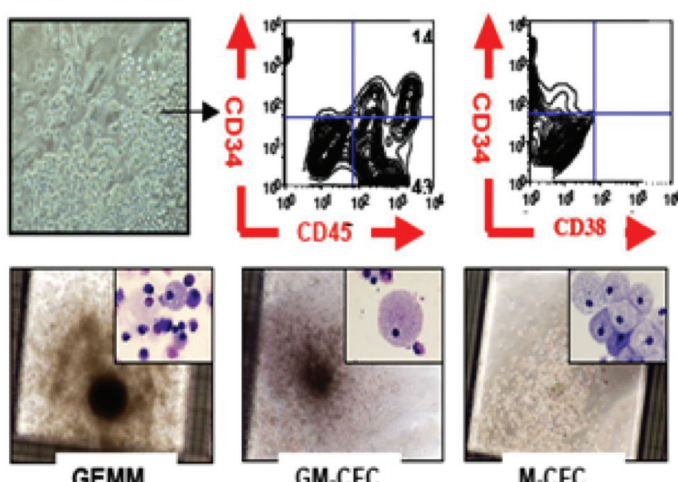

C

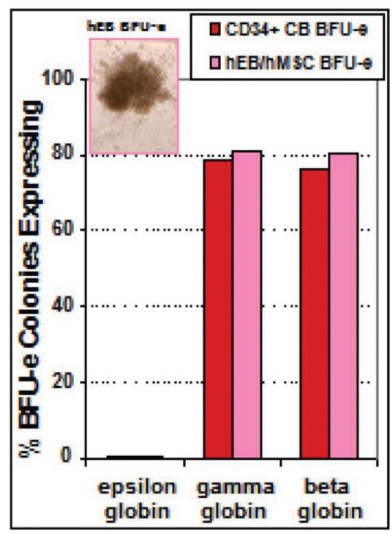
ing reculture into serumfree and stromal-free culture conditions; or definitive GlyA+ CD45+ erythro-myeloid cells if alternatively cultured on OP9 bone marrowstromal layers. Figure adapted from Zambidis et al., 2008, with permission. (B-D) Generation of e n g r a f t $a$ b l e $C D 34^{+} C D 45^{+} C D 38$ adulttype definitive-type hematopoietic progenitors from $A C E^{+}$hEB-derived human hemangioblasts following in vitro maturation on mesenchymal stromal niches, or in vivo injection into mouse neonatal livers. (B) Day 9 to 10 FACS-sorted $A C E^{+}{ }^{C} D 34^{+}$ and $\mathrm{ACE}^{+} \mathrm{CD} 43^{+} \mathrm{hEB}$ populations (from Line H1

(WA01)) containing
hemangioblasts were cultured on hu-
D
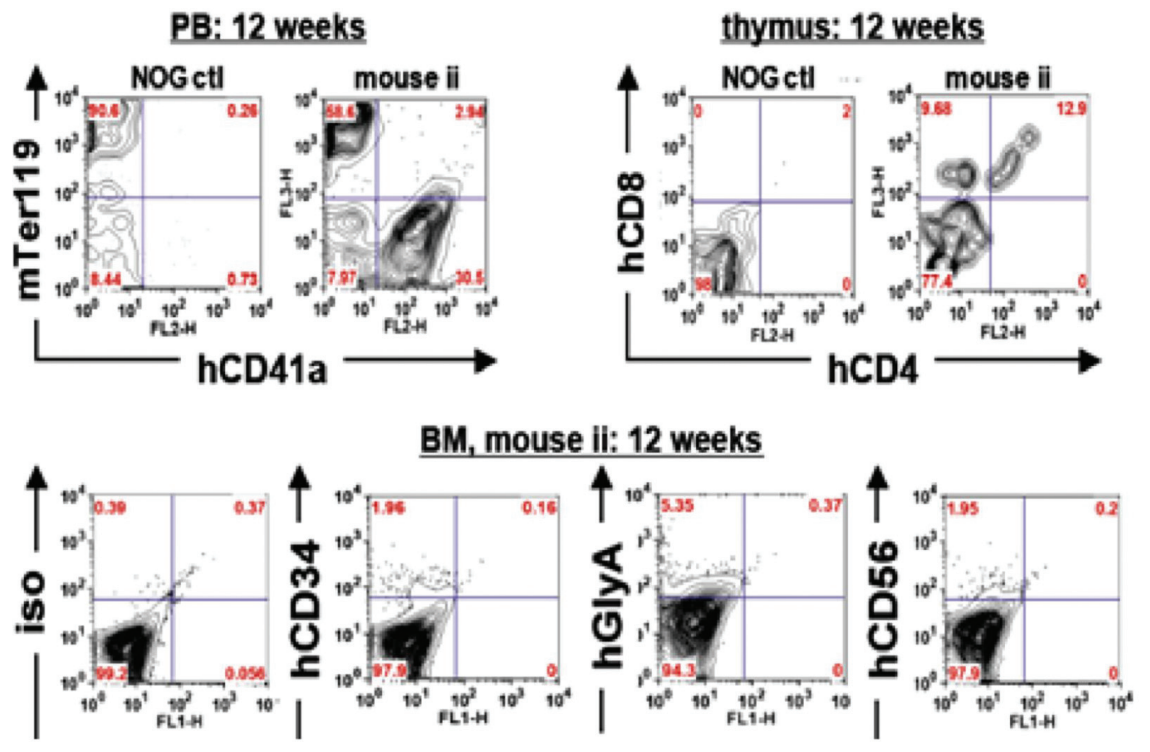
man mesenchymal stromal cells (hMSC), and supplemented with human hematopoietic growth factors. This co-culture system differentiated YS-like $\mathrm{ACE}^{+} \mathrm{CD} 34^{+}$hEB cells into "cobblestone"-appearing CD $34^{+} C D 45^{+}$CD 38 cells that generated abundant definitive CFU in methylcellulose assays (GEMM-CFC, GM$C F C$, and M-CFC shown, as well as GCFC, BFU-e, CFU-e) that were indistinguishable from $\mathrm{CD} 34^{+}$cord blood (CB) control colonies. (C) These hEBderived erythroid $C F U$ resembled $C B$ $B F U$-e in morphology and adult hemoglobin expression with low intracytoplasmic embryonic globin (epsilon), and high amounts of fetal (gamma) and adult globin (beta) expressions. (D) Analysis of in vivo maturation of hEB-derived cells following injection of stroma-differentiated $h E B$ into the neonatal liver of highly immunodeficient, irradiated (150 Gy) NOD/SCID/IL2Rgnull (NOG) mice ( $n=4)$. At 12 weeks, there was evidence for multi-lineage lympho-erythro-myeloid engraftment; peripheral blood (PB) FACS analysis detected high levels of mouse erythroid marker Ter119and human CD41a (hCD41a), a megakaryocyte marker. Double positive $h C D 4^{+} \mathrm{CD} 8^{+}$hematopoietic cells in the thymus demonstrated mature $T$ cell maturation/engraftment, while low levels of detectable hCD34, hGlycophorin A (CD235a), and hCD56 were found in the bone marrow of transplanted NOG mice. 
the cardiovascular system through G-protein-coupled interactions, AGTR2 is rarely expressed in adult tissues (Grady et al., 1991; Akishita et al., 1999), suggesting a key role during early development.

In our studies (Zambidis et al., 2008), we demonstrated a dramatic upregulation of AGTR2 during expansion of hEB-derived $\mathrm{ACE}^{+}$hemangioblasts, which suggests a unique role for the renin-angiotensin axis in guiding the initial developmental phases of human angio-hematopoiesis (Hubert et al., 2006; Heffelfinger, 2007). Indeed, we found that hEB-derived BL-CFC could be directed to differentiate into either hematopoietic or endothelial progeny by manipulating signaling pathways normally mediated by the renin-angiotensin axis. Firstly, enzymatic ACE activity was required for $h E B$-derived hemangioblast expansion since the specific ACE inhibitor Captopril dramatically blocked BL-CFC formation, suggesting a requirement for Ang II peptide synthesis, and/or downstream AGTR signaling. Moreover, manipulation of angiotensin II signaling with either AGTR1- or AGTR2-specific inhibitors resulted in pronounced deviations of $h E B$ differentiation toward either endothelium, or multipotent hematopoietic progenitors. For example, specific blockade of AGTR1 signaling with Losartan significantly boosted hEB-derived hematopoietic colonyforming cells (CFC) formation, especially the generation of multipotent mixed CFC. To determine if AGTR inhibitors acted either directly on hemangioblast expansion, or via indirect amplification of more committed progenitors, we included these blockers in clonogenic BL-CFC assays. Secondary replating of AGTR1inhibited (Losartan) blast colonies produced predominately hematopoietic cell lineages, with limited endothelial differentiation. In contrast, replating of blast colonies treated with an AGTR2specific inhibitor (PD123-319) resulted in predominantly endothelial progeny, with limited hematopoietic differentiation. Thus, AGTR2 function was necessary for expansion of hemangioblast colonies into multipotent hematopoietic progenitors, and its inhibition with PD123-319 completely abolished hematopoietic differentiation, while imposing an almost exclusive endothelial fate on hemangioblast colonies.

Since AGTR2 signaling is known to antagonize AGTR1 signaling directly (Hubert et al., 2006), our data implicated a general mechanism by which emerging hemangioblasts in the YS or AGM may be directed to differentiate by the hematopoietic stem cell niche. One hypothesis is that antagonistic competition between AGTR2 and AGTR1 for Ang II binding on emerging hemangioblasts directs their development into either hematopoietic progenitors, or alternatively into vascular-endothelial networks. Finally, these studies suggest that manipulation of AGTR2 signaling could be an important strategy, in general, for expanding multipotent hematopoietic progenitors from primitive HSC. We speculated that AGTR1/ AGTR2-regulated stem cell proliferation may be a generalized phenomenon, since AGTR1 inhibition by Losartan was reported to increase skeletal muscle regeneration in patients with primary muscular dystrophies (Cohn et al., 2007), and the renin-angiotensin axis critically influences normal fetal development, since both ACE and AGTR1 receptor blockers are teratogenic. AGTR2 signaling, in particular, is known to regulate cellular growth and apoptosis during vascular and neural development (Grammatopoulos et al., 2005; Savary et al., 2005). Interestingly, mutations of $A G T R 2$ have been reported in patients with severe mental retardation and autism (Vervoort et al., 2002), thus further substantiating a role for the renin-angiotensin system in directing the proper development of the nervous system.

\section{Generation of engraftable definitive adult-type HSC may require developmental maturation of mesodermal precursors in specific mesenchymal stromal niches}

Although we initially demonstrated that $\mathrm{hESC}$, like mESC, primarily model the developmental steps associated with primitive YS extra-embryonic hematopoiesis, it is not yet clear if hESC differentiation can model the definitive, AGM-like lympho-hematopoiesis that normally arises from the intra-embryonic AGM. EB or stromal-based differentiation protocols described thus far have shown that both $\mathrm{mESC}$ and hESC-derived hematopoietic progenitors have a YS molecular and cellular phenotype with limited long-term engrafting potential in adult recipients (Potocnik et al., 1997; Matsuoka et al., 2001; Miyagi et al., 2002), which is a defining feature only of AGM-derived HSC. Since YS progenitors can be conditioned into engrafting, definitive HSC following co-culture on appropriate stromal niches (Matsuoka et al., 2001), these hematopoietic progenitors may be inherently deficient in a "definitive HSC instructive program" that can be provided only by an in vivo mesenchymal AGM, fetal liver, or bone marrow niche. We recently demonstrated that hESC-derived CD $34^{+}$cells committed in culture into hemato-endothelial cell progenitors could be further developed into mature blood and vascular cells following transplantation into chicken embryo yolk sacs (Park et al., 2009). These observations not only demonstrated the utility of the avian embryo as a convenient and reliable host to model the angiohematopoietic development of hESC, but they also underscored the importance of evaluating how in vivo niches can mature primitive progenitors into adult hematopoiesis.

Extensive experimental evidence has suggested that mesenchymal stromal niches are regulators of the native adult HSC niche. Bone morphogenetic protein (BMP)-responsive mesenchymal stromal cells (MSC), for example, are found in hematopoietic sites during ontogeny, and are key components of the HSCsupportive micro-environmental niche by activating, or differentiating into supportive cells (e.g., osteoblasts). Osteoblasts, in turn, express Notch ligands (e.g. Jagged1) and can increase HSC numbers via niche-mediated Notch signaling (Noort et al., 2002; Angelopoulou et al., 2003; Arai et al., 2004; Bensidhoum et al., 2004; Sammons et al., 2004; Koch et al., 2005; Martin and Bhatia, 2005; Mendes et al., 2005; Adams et al., 2006; Francois et al., 2006; Friedman etal., 2006; Muguruma et al., 2006; Suzuki et al., 2006). Notch signal transduction may be critical in determining definitive HSC maturation and expansion, and mediates multiple key cell fate decisions via the lateral inhibition of cell fate mechanism, or inductive signaling. NOTCH1 and NOTCH2 are expressed in adult human $\mathrm{CD} 34^{+} \mathrm{HSC}$, and their ligand JAGGED1 is expressed on bone marrow osteoblasts, suggesting direct involvement in the regulation of $\mathrm{HSC}$ by the stromal microenvironment (Calvi et al., 2003; Zhang et al., 2003; Taichman, 2005; Wilson and Trumpp, 2006). Although the Notch pathway plays a major role in lymphopoietic lineage decisions, its role in the genesis and maintenance of HSCs is only beginning to emerge. Embryonic Notch $1 \%$ knockout mice have severely impaired hematopoiesis (Kumano et al., 2003) due to an inability of hemangioblasts in the AGM region to differentiate into definitive 
HSC. In contrast, mEB-based studies showed that the Notch-/phenotype does not affect YS hematopoiesis, whereas AGM-type definitive HSC generation is defunct (Hadland et al., 2004; Robert-Moreno et al., 2005), and likely depends on a Notch-Runx1 interaction.

Indeed, Notch-Runx1 signaling may be central to the initial "executive" decision-making process that generates definitive murine HSC at its embryonic AGM origin. There is abundant evidence that Runx1 is a key regulator of definitive HSC emergence in the AGM, where it is indispensable for formation of longterm engrafting $\mathrm{CD}_{4}{ }^{+} \mathrm{C}-\mathrm{kit}^{+} \mathrm{HSC}$ (North et al., 1999; North et al., 2002). Runx1 binds DNA as a heterodimer with CBF $\beta$, and neither Run $\times 1^{-/}$nor $C B F \beta^{-/}$mutant embryos can develop definitive HSCs (Okuda et al., 1996; Wang et al., 1996). In contrast, targeted deletion of Runx1 in adult mice leads to hematopoietic abnormalities but preservation of HSC (North et al., 1999; Nakagawa et al., 2006). While other factors associated with hematopoietic emergence, such as the bHLH factor SCL (Robb etal., 1995; Shivdasani et al., 1995), play critical roles in both primitive and definitive hematopoieses, only Runx1 is uniquely required for the emergence of definitive, long-term engrafting HSCs. In human embryos, control of a NOTCH-RUNX1 axis may simply be mediated by regulating the expression of Notch proteins per se. NOTCH-1, 2, 4, and ligands DELTA1-4, and JAGGED1, for example, are not expressed in human YS sites, but expression appears later in the fetal liver when fetal definitive HSCs first expand (Dando et al., 2005).

Multiple lines of evidence now support the concept that primitive hematopoietic progenitors, such as those generated from ESC can develop into an adult definitive phenotype with appropriate stromal contact. For example, co-culture of hESC on primary stromal cells derived from murine embryonic day E10.5 AGM, or E12.5 fetal liver stromal cell lines significantly increased definitive CFC activity (Krassowska et al., 2006; Ledran et al., 2008). AGM stromal cell lines, in particular enhanced hematopoietic mesoderm differentiation with subsequently increased hematopoietic progenitor cell formation. Direct cell-cell contact and paracrine signaling with stroma was necessary to mature hESC into definitive hematopoietic cell lineages since conditioned media and extracellular matrix from these stromal cell lines alone abolished or significant reduced definitive CFC activity. These studies suggested a role for TGF $\beta 1$ and TGF $\beta 3$ in definitive hematopoietic induction. Nonetheless, evidence for generation of a true adult AGM-type definitive HSC has not yet been conclusively demonstrated in these recently published methodologies (Tian et al., 2006; Ledran et al., 2008). Similar to previous reports (Wang et al., 2005a), erythropoiesis generated from engrafted cells in these latter studies was still at an embryonic/fetal stage. Furthermore, primary engraftment in immunodeficient murine recipients remained low, short-term (<3 months), displayed limited lymphopoiesis, and had low subsequent secondary engraftment frequencies. These characteristics of poor lympho-hematopoietic engraftment are consistent with hESC-derived progenitors possessing an embryonic YS, and not adult-type definitive phenotype.

Another study, using preimmune fetal sheep recipients of $h E B$ derived $\mathrm{CD}_{3}{ }^{+} \mathrm{CD} 38^{-}$-Lin38- cells demonstrated low levels of human hematopoietic cell long-term primary and secondary transplant engraftment potential $(0.05 \%-0.2 \%$; evaluated at $10-39$ months post injections) (Narayan et al., 2006). Since the bone marrow of these fetal recipients was not conditioned (e.g., with irradiation or busulfan) prior to cell transplantation, however, it is unclear whether the low engraftment frequency observed would be sufficient to expand or ensure their survival postnatally.

To further elucidate the role of mesenchymal stromal niches in generation of definitive HSC, our group has begun related experiments, as those described above. We co-cultured FACS-purified $\mathrm{ACE}^{+} \mathrm{CD} 34^{+}$-derived hemangioblasts from differentiated day 910 hEB onto E12.5-E14.5 murine fetal liver (FL) stroma (Fig. 3 BD), or human MSC (hMSC), and supplemented these cultures with human hematopoietic growth factors. Under these conditions, purified $\mathrm{YS}$-like $\mathrm{ACE}^{+} \mathrm{CD} 34^{+}$hemangioblasts differentiated into "cobblestone"-appearing $\mathrm{CD} 34^{+} \mathrm{CD} 45^{+} \mathrm{CD} 38$ - cells that produced abundant definitive-type CFU (GM-CFC, G-CFC, M-CFC, GEMM-CFC, BFU-e, CFU-e) in methylcellulose assays. These hematopoietic colonies were indistinguishable from cord blood $\mathrm{CD}_{4}{ }^{+}$cell colony controls (Fig. $3 \mathrm{~B}, \mathrm{C}$ ). hEB-derived erythroid CFU-e, for example, were indistinguishable from CB CFU-e in both morphology, and in their expression patterns of adult hemoglobin with low intracytoplasmic embryonic globin (epsilon), and high amounts of neonatal/adult gamma and beta globin expression, in comparison to hEB-derived CFU-e that persist in their expression of embryonic globins (Fig. 3C). More importantly, these stroma-differentiated hEB cells are only capable of shortterm (evaluated at 12 weeks), multilineage lympho-erythromyeloid engraftment following injection into the neonatal livers of highly immunodeficient, irradiated NOD/SCID/IL2Rg ${ }^{\text {null }}$ (NOG) mice (Fig. $3 \mathrm{C})$. These pilot experiments strongly suggest that a proper hematopoietic microenvironment (e.g., as provided by hMSC osteoblastic or FL-type stroma), can indeed pattern YS-like hEB progenitors into at least short-term (12 weeks) engraftable, adulttype progenitors.

In summary, although unclear at this time, in vitro generation of engraftable definitive HSC may require a recreation of their in vivo stem cell niche milieu. As illustrated above, a better understanding of the relevant growth factors and signaling molecules that activate definitive HSC-specific genes from primitive progenitors is needed. Experiments that define the critical components of the definitive HSC niche will probably also rely on additional methods for enhancing the homing of these ex vivo-generated HSC following transplantation and engraftment into conditioned recipients.

\section{The role of homeobox (HOX)-regulating factors (CDX, $M L L$ ) in determining definitive HSC genesis and self- renewal}

Although multiple factors such as BMP4, activin A, VEGF, FGF2, Hedgehog, TPO, and Wnt factors are implicated in the generation and downstream self renewal of HSC from mesoderm (Johansson and Wiles, 1995; Bhatia et al., 1999; Faloon et al., 2000; Baron, 2001; Dyer et al., 2001; Lako et al., 2001; Li et al., 2001a; Adelman et al., 2002; Byrd et al., 2002; Murdoch et al., 2002; Perlingeiro et al., 2003; Reya et al., 2003; Willert et al., 2003), the upstream molecular "switch" for patterning hematopoietic mesoderm into HSC remains obscure, yet vital for understanding how to differentiate hESC toward adult-type definitive HSC. Multiple studies have suggested that the regulated control 
of $H O X$ genes may be the effectors for this upstream "definitive HSC-genesis" switch. Thus, in addition to patterning hESCderived cells into definitive HSC by recapitulating hematopoietic stem cell niches, manipulation of $H O X$ gene expression may also serve a role in generating long-term engraftable HSC from pluripotent stem cells.

HOX proteins are a highly-conserved group of transcription factors characterized by a 60-amino acid DNA-binding motif termed the homeodomain. HOX genes are organized into four major genomic clusters (A, B, C, D), and play crucial roles in embryonic organogenesis. Clusters $A-C$ are expressed at high levels in normal HSC, and have been widely implicated in HSC self-renewal and regulation. Notably, HOXB4 has been exploited for its ability to expand engraftable human HSC (Antonchuk et al., 2002). Additionally, multiple HOXgenes participate as leukemic translocation partners, or are dysregulated in leukemias with normal karyotypes (Antonchuk et al., 2002; Owens and Hawley, 2002; Grier et al., 2005), further implicating their role in HSC selfrenewal.

Loss-of-function studies have shown that most HOX genes have redundant functions, whereas gene disruption of upstream HOX-regulators such as MEIS1, PBX1, MLL, and CDX genes results in severe hematopoietic phenotypes (Yu et al., 1995; Antonchuk etal., 2002; Owens and Hawley, 2002; Davidson etal., 2003; Krosl et al., 2003; Abramovich and Humphries, 2005; Davidson and Zon, 2006), suggesting that these genes directly regulate HSC genesis or expansion. HOX regulation by the highly conserved CAUDAL family of genes (CDX1,CDX2, and CDX4) (Chawengsaksophak et al., 2004; Shimizu et al., 2006) was recently established. $C D X$ genes encode a family of homeodomain transcription factors that regulate anterior-posterior embryonic patterning by orchestrating the specific expression of $\mathrm{HOX}$ genes during ectodermal and mesodermal development (Epstein et al., 1997; Charite et al., 1998; Reece-Hoyes et al., 2005). The normal embryonic expression pattern of $c d x 4$, for example, appears to be tightly regulated in Xenopus (Reece-Hoyes etal., 2005), zebrafish (Rawat etal., 2004), and mouse development (Gamer and Wright, 1993; Horn and Ashworth, 1995; Epstein et al., 1997; Charite et al., 1998; Rawat et al., 2004). Cdx4 is first detected in the posterior embryo during gastrulation and somitogenesis, and its expression domains in lateral plate mesoderm include the hematopoietic-initiating tissues of the allantois and early YS wall cells (which also co-express sch).

$\mathrm{C} d \times 2$ and $c d \times 4$ function are likely redundant, yet critical for patterning mesoderm to primitive hematopoietic lineages. Zebrafish "kugelig "cdx4-mutants (Davidson etal., 2003), showed that cdx4 makes posterior mesoderm competent for subsequent hematopoietic commitment (possibly at the hemangioblast stage) by upregulating target Hoxgenes $H 0 \times A 6, H o x B 3, H o x B 4, H o x B 8$, and HoxC6. Additionally, $\mathrm{cdx} 1 \mathrm{a}$ and $\mathrm{cd} \times 4$ (redundantly) regulate the genesis of downstream runx1a+ definitive HSC derived from the AGM region (Davidson and Zon, 2006), thus implicating a role of $c d x$ genes in both primitive and definitive hematopoieses. These zebrafish studies reveal a novel vertebrate cdx-hox axis that may act as the long-sought-after instructive signal for HSC genesis from a hemangioblast. Indeed, Daley's group recently strengthened this hypothesis by generating transplantable, multilineage HSC via retroviral co-expression of both $\mathrm{Cd} \times 4$ and Hoxb4 in mEB progenitors (Wang et al., 2005). In contrast, dysregulated expression of $C d x$ genes results in various malignancies (Chawengsaksophak et al., 1997; Rawat et al., 2004) overexpression of $\mathrm{C} d \times 2 / \mathrm{Cd} \times 4$ is leukemogenic either alone (Bansal et al., 2006), with fusion partners (Rawat et al., 2004), or most potently when co-expressed with HOX cofactors (Bansal et al., 2006). Although our group reported $C D X 4$ expression in primitive hEB-derived hematopoietic progenitors (Zambidis et al., 2005), human $C D X$ function remains technically difficult to study, since $C D X$ expression is restricted to embryonic development. Interestingly, a recent report described $C D X 4$ overexpression in human acute leukemias with both normal karyotypes or $t(9 ; 11) \mathrm{MLL}$ fusions (Bansal et al., 2006). The mixed lineage leukemia (MLL) proto-oncogene is a better-characterized $\mathrm{HOX}$-regulator than $C D X . \mathrm{MLL}$ is a histone methyltransferase involved in recurrent (11q23) translocations found in $~ 80 \%$ of infant and $10 \%$ of adult leukemias (Tkachuk et al., 1992; Corral et al., 1993; Yu et al., 1998; Hess, 2004; Eguchi et al., 2005). These aggressive leukemias often have biphenotypic myeloid-lymphoid markers, and a very poor prognosis (Poirel et al., 1996; Pui et al., 2002). The Nterminal portion of MLL is known to be fused in-frame to over 40 known (apparently disparate) leukemogenic fusion partners that all elaborate a common pathologic motif: aberrant activation of HOXgenes via direct transcriptional activation (Joh et al., 1996; Dobson et al., 1999; Joh et al., 1999; Ayton and Cleary, 2003; Cozzio et al., 2003; Ferrando et al., 2003; Forster et al., 2003; Johnson et al., 2003; Martin et al., 2003; Rozovskaia et al., 2003; Zeisig et al., 2004; Milne et al., 2005a; Milne et al., 2005b; Chen et al., 2006; Kong et al., 2006; Krivtsov et al., 2006; Meyer et al., 2006; Somervaille and Cleary, 2006). The normal wildtype MLL gene encodes a Trithorax-group chromatin regulator essential in Hox-mediated body specification (Yu et al., 1995), but also specifically necessary for definitive lympho-hematopoietic stem cell genesis (Fidanza et al., 1996; Hess et al., 1997). MI/-- mouse embryos and mEB have revealed a crucial role for Mll in definitive HSC development in the AGM (Ernst et al., 2004a; Ernst et al., 2004b). Although primitive hemangioblast development appears intact in differentiating $M \mathrm{IF}^{-} \mathrm{mEB}$, downstream definitive-type progenitors from $m E B$ or AGM regions are deficient, and correlate to a paucity of Hoxgene upregulation. Engraftable AGM-derived $\mathrm{HSC}$, for example, could not be generated from $\mathrm{MII}^{-/-}$murine embryos, although ectopic expression of $\mathrm{Cdx} 4$ in $M / \mathrm{F}^{-} \mathrm{mEB}$ partially rescues their hematopoietic deficiency, thus implicating a potential Cdx-MII-Hox axis. A better understanding of a CDX4MLL-HOX axis in humans may reveal efficient strategies for expanding definitive HSC from primitive hEB-derived progenitors.

Manipulation of $H O X$ gene expression to derive engraftable hESC-derived hematopoietic progenitors has already been reported, but with limited success compared to murine ESC systems. Generation of long-term engraftable hematopoietic cells from mouse ESC-derived cells using ectopic Hoxb4/Cdx4 expression (Kyba et al., 2002; Wang et al., 2005a), for example, raised the possibility that similar studies could result in the derivation of definitive HSC from hESC (Wang et al., 2005b). While HOXB4vector-transduced hEB-derived progenitors generated a $\sim 2.5$ fold increase in hematopoietic cell expansion, it did not lead to the maturation of hESC-derived hematopoietic cells into long-term engraftable HSC as was, in contrast, shown in mice. This discrepancy between mESC and hESC systems remains 
unresolved, although it remains possible that other $H O X$-regulating factors such as MLL or CDX are more potent than HOXB4 for maturing hESC-derived cells into definitive HSC. Moreover, there are likely many other undiscovered HOX-related factors that might play important roles for patterning definitive HSC from primitive hemangioblasts, although the search for such factors should be tempered by the concomitant oncogenicity that ectopic HOX factor expression inevitably results in. In fact, expression analysis of other genes important for HSC physiology, behavior, self-renewal, and in vivomaintenance has already revealed major differences between hESC-derived and adult hematopoietic progenitors. hESC-derived hematopoietic progenitors, for example, express high levels of cell-cycle proteins, and reduced levels of expression of genes important in stem cell self-renewal. In contrast, adult somatic HSC show upregulation of multiple genes involved in quiescence and HSC renewal such as cyclin G2, p53 binding protein, p21, and p57 (Wang et al., 2005b).

\section{Definitive, long-term engraftable HSC may arise from distinct mesodermal precursors of a different origin than the YS hemangioblast}

Although it was originally suggested that the same population of HSC found in the embryonic YS also supplied the fetus and adult (Weissman etal., 1978), it is now generally accepted that the majority of adult-type blood-forming stem cells likely arise independently from endothelium-associated cell clusters localized on the ventral aspect of the dorsal aorta and vitelline artery in the AGM (e.g., between days 27-40 for human development; (Tavian et al., 1999a)). These CD34+CD31+CD45+CD38- endotheliumadherent cells yield long-term hematopoietic, myeloid and lymphoid cells, while their counterparts in the YS only produce erythro-myeloid lineages (Tavian et al., 1996; Tavian et al., 1999b; Tavian et al., 2001).

Nonetheless, the developmental origins of adult HSC that arise from the AGM currently remains elusive. The majority of YS hematopoietic progenitors likely survive only long enough to support organogenesis in the rapidly developing embryo. In contrast, HSC generated within the aortic floor (e.g., via hemogenic endothelium), or from mesenchymal cells within the subaortic patches, or perhaps directly from a non-mesenchymal lateral plate mesoderm-derived hemangioblastic progenitor (Fig. 1A) likely provide the long-term source of adult hematopoiesis (Jaffredo et al., 2005).

Although murine AGM-derived progenitors show long-term engraftment properties and recapitulation of the entire adult blood system when injected into the bone marrow of lethally-irradiated adult mice (Medvinsky and Dzierzak, 1996; Cumano et al., 2001), it has not been excluded that the primitive hemangioblast (derived from extraembryonic mesoderm, and which dictates ephemeral YS hematopoiesis) could also contribute to the definitive HSC population found in the adult to some extent. Several studies have suggested the possibility that blood-forming stem cell clusters originating in the YS subsequently mature as they transverse through the embryo to the AGM, where they initiate definitive HSC formation. Recent studies, for example, using an inducible lac $Z$ cell-labeling system which genetically marked YS-derived Runx1/ $\mathrm{Aml}^{+}$cells, proposed that adult HSC in murine bone marrow originate from a combination of progenitors derived from ances- tral extraembryonic mesoderm-derived YS blood islands, and lateral-plate mesoderm-derived AGM blood stem cell clusters (Samokhvalov et al., 2007; Ueno and Weissman, 2007). At E7.5 of mouse development, the expression of Runx 1 (which is crucial for hematopoietic emergence) is limited in expression only to cells found in the YS, since vascular cell trafficking connections between the YS and the embryo have not yet been established. Intriguingly, the genetic tracking of these Runx $1^{+}$cells for up to a year in the adult, demonstrated that these YS-derived cells could contribute to the adult HSC population found in the bone marrow (albeit in limited amounts $(\sim 1-10 \%))$. These results indicate that YS blood progenitors can, indeed, play a role in contributing to the pool of adult, long-term reconstituting lympho-hematopoietic stem cells.

In summary, the spatial separation of the extraembryonic mesoderm and lateral plate mesoderm that form primitive and definitive hematopoiesis respectively, raises the possibility that two types of mesoderm may produce qualitatively different hemangioblasts with differing cell lineage potentials, gene expression patterns, and perhaps epigenetic changes (Fig. $1 \mathrm{~A}, \mathrm{~B}$ ). It remains to be seen whether the hESC-derived YS-like hemangioblasts we have described can be further matured into definitive HSC by means of recreating their natural in vivo microenvironments. An alternative approach is to devise hESC differentiation strategies that generate lateral plate/AGM-type mesoderm, rather than YS-type extraembryonic mesoderm. Toward this end, the mouse model has provided numerous insights into methods for improving lateral plate mesoderm differentiation based on a complex signalling network that directs epiblast patterning and primitive streak formation (Tam and Beddington, 1987; Ang and Constam, 2004). In particular, the key regulators of in vivo mesodermal induction, which we review below, would have to be recapitulated in vitro.

\section{Targeted use of mesodermal morphogens may en- hance the efficiency of hemangioblast and HSC gen- eration from human pluripotent stem cells}

A better understanding of the signaling pathways and growth factor environments that differentiating hESC are exposed to may guide enhanced mesodermal differentiation, and subsequent hemangioblast-HSC generation. Specifically, a detailed map of mesodermal transcriptional control could lead to the formation of an in vitrosystem that can specifically direct cellular differentiation into either extraembryonic (YS), or lateral plate (AGM) mesoderm, and thus give rise to distinct types of hematopoietic progenitors. For example, the duration, location and concentration of key selected signaling pathways (e.g., NODAL, TGF $\beta$, WNT, and FGF) are thought to play critical roles in the development of distinct mesodermal populations during primitive streak formation (Ben-Haim et al., 2006). Below, we briefly review the known mechanisms of some of these key morphogens, which we suggest will have to be properly manipulated in vitrofor proper hESC mesodermal-hemangioblast differentiation.

\section{NODAL establishes the proximal-distal axis and mesoendoderm specification of the embryo}

NODAL expression is first detected in the inner cell mass and primitive endoderm at mouse embryonic day E4.5 (Varlet et al., 
1997), where it maintains the expression of the pluripotency markers Pou5f1(Oct4) and Nanogin the epiblast (Mesnard et al., 2006). In addition to a role in pluripotency, NODAL is also required for primitive streak formation (Conlon et al., 1994). Around E5.0, a subset of visceral endoderm at the distal tip of the embryo responds to NODAL signalling by expressing a specific repertoire of genes (Brennan et al., 2001) including the NODAL antagonists, Lefty1 (Perea-Gomez et al., 1999) and Cer1(Belo et al., 1997). The combination of a proximally located source of NODAL and a distally located source of NODAL antagonists creates a gradient of NODAL signalling with highest expression at the extraembryonic/epiblast boundary (Lu et al., 2004). Around E5.5 the Cer1 and Lefty1-expressing cells migrate anteriorly, rotating the area of NODAL inhibition, which results in higher NODAL signalling in the posterior part of the embryo (Kimura et al., 2000; Perea-Gomez et al., 2002; Yamamoto et al., 2004). Loss of NODAL signalling leads to the absence of anterior primitive streak mesoderm derivatives and definitive endoderm (Beck etal., 2002; Yamamoto et al., 2004). In contrast, elevation of NODAL signaling due to transcriptional loss of a co-repressor or expression of a NODAL antagonist, results in the over-expression of mesodermal markers (Meno et al., 1999; Perea-Gomez et al., 2002). In hESCs, a role for NODAL in maintaining pluripotency, and inhibiting neuroectodermal differentiation (Vallier et al., 2004; Smith et al., 2008; Wu etal., 2008) has been described, but its role in mesoendoderm differentiation has not yet been deciphered, but will likely be dependent on the duration and magnitude of NODAL signaling (Vincent et al., 2003).

Activin A, although dispensable for mouse gastrulation (Matzuk, et al., 1995), binds to the same receptors as NODAL, and is thought to mimic some of its activities. In Xenopus, exogenous activin $A$ is well-characterized as a mesoderm inducer (Ariizumi et al., 1991). Indeed, activin A has been used to improve hESC differentiation into mesodermal lineages (Schuldiner et al., 2000; Burridge et al., 2007; Yang et al., 2008), although its addition to hESCs also conversely induced endodermal, rather than mesodermal lineages (Levenberg et al., 2003; D’Amour et al., 2005; Hay et al., 2008; Ishii et al., 2008), requiring the suppression of $\mathrm{PI} \mathrm{K}$ signaling through insulin/IGF inhibition (McLean et al., 2007). This apparent paradox in activin A activity may likely be explained by dose dependent effect, as seen in Xenopus animal caps, where lower concentrations promote mesodermal lineages, and higher concentrations promote endodermal lineages (Okabayashi and Asashima, 2003). As with NODAL, the use of activin A to maintain hESC pluripotency has also been described (Beattie et al., 2005; James et al., 2005; Xiao et al., 2006).

\section{BMP4 signals from the extraembryonic ectoderm induce mesoderm formation}

The high levels of NODAL expression in the proximal epiblast at E5.0 also maintain BMP4 expression in extraembryonic ectoderm adjacent to the epiblast (Brennan et al., 2001; Ben-Haim et al., 2006). BMP4 is required for mesoderm formation and patterning (Winnier et al., 1995) and acts by inducing WNT3 expression in the proximal epiblast (Liu et al., 1999). The distal visceral endoderm that expresses NODAL inhibitors also expresses WNT3 inhibitors such as DKK1, which similarly results in the movement of WNT3 expression towards the posterior epiblast (Glinka et al., 1998; Kemp et al., 2005). It is at this pregastrulation stage that the expression of mesoendodermal markers such as $T$ (Wilkinson et al., 1990), Mix/1 ((Pearce and Evans, 1999), Eomes (Ciruna and Rossant, 1999), and Gsc (Blum et al., 1992) is detected.

\section{Fibroblast Growth Factors (FGFs) control mesoderm pattering and maintenance}

In contrast to NODAL, FGFs control the specification of and maintenance of mesoderm rather than primary mesoderm induction (Burdsal et al., 1998; Ciruna and Rossant, 1999). Mutational analyses of the known Fgfgenes have demonstrated that only Fgf4 and Fgf8 are required for early embryonic development (Niswander and Martin, 1992; Crossley and Martin, 1995; Ciruna and Rossant, 1999; Sun et al., 1999). Although FGF2 has a well established role in maintaining hESC pluripotency, when hESC are differentiated and FGF receptor signalling is inhibited by SU5402, hEBs demonstrate a significant reduction in expansion by day 4 and $<1 \%$ cell survival by day 8 (Vallier et al., 2005). Additionally, a dominant negative FGFR2 abrogated the formation of the primitive ectoderm layer in $\mathrm{mEB}$ s by affecting basement membrane formation, and mEBs became necrotic after 6-8 days (Li et al., 2001b). These results suggest that FGF2 signalling is essential for EB growth and development.

Unpatterned mesoderm expresses KDR/flk-1 (VEGFR2) (Ema et al., 2006), and PDGFRA, the alpha receptor of platelet derived growth factor (Takakura et al., 1997). Lateral plate mesoderm, which forms the hematopoietic lineages, subsequently downregulates PDGFRA, whereas paraxial mesoderm downregulates KDR (Sakurai etal., 2006). In addition, the expression of $\mathrm{KDR} / \mathrm{flk}-1$ is maintained in hemangioblasts and HSC (Ziegler et al., 1999). Furthermore, the addition of VEGFA during mESC hematopoietic differentiation has been shown to enhance the effects of BMP4 (Nakayama et al., 2000; Park et al., 2004). Similarly, abundant insulin growth factor 2 (IGF2) expression in gastrulating mouse embryo mesoderm, and an impairment of in vitro mesoderm differentiation of $1 \mathrm{gf}^{2 /-} \mathrm{mESC}$, suggested that IGF2 plays an important role in the induction of mesoderm during development. Addition of exogenous IGF2 to in vitro cultures of lgf2/- differentiating $\mathrm{mESC}$ rescued mesoderm formation and expression of mesodermal markers (Morali et al., 2000)

Our group has already begun to test the effects of these critical morphogens on hEB hematopoietic lineage generation using our novel serum-free hEB differentiation system. We recently described that, in the absence of serum, the minimal combination of VEGFA, BMP4, and FGF2/heparan (VBF2) was necessary and sufficient for efficiently inducing hematopoiesis in differentiating hESC (Zambidis et al., 2008). Further supplementation of mesodermal morphogens such as NODAL, WNT3A, IGF2, or activin A to developing hEB appeared to mimic some of the in vivo mesoderm-enhancing effects described above (Fig. 4). In particular, the addition of NODAL to the minimal VBF2 combination led to a significant increase of total hematopoietic CFC, multipotent CFC, and primitive and definitive erythrocytes, in comparison to VBF2 alone. Addition of WNT3A, a downstream effector of NODAL, to VBF2 also modestly increased the same populations of hematopoietic cells with the exception of definitive erythrocytes, suggesting that this factor primarily enhances the formation of primitive YS cells. Likewise, addition of IGF2 to VBF2 augmented only modestly the total formation of hematopoietic CFC, multipotent CFC, and primitive and definitive erythroid CFC, although this 
combination appeared to greatly enhance myeloid lineage differentiation. Our current efforts are focused on isolating distinct mesodermal progenitors from these optimized morphogen-treated $\mathrm{hEB}$ cultures, and assaying their primitive and definitive hematopoietic potential.

\section{Role of microRNAs in pluripotency and directed differ- entiation of hESC into hemangioblasts and HSC}

MicroRNAs (miRNAs) have recently been found to play critical roles in embryonic differentiation and developmental timing of cellular differentiation, including hematopoietic lineage specification. MiRNAs are small, approximately 22 nucleotide-long noncoding RNAs that post-transcriptionally regulate gene ex- pression (Lee et al., 1993; Lagos-Quintana et al., 2001; Lau et al., 2001; Lee and Ambros, 2001; Ruvkun, 2001). MiRNAs are transcribed by POL II as loop-structured pre-miRNAs, processed by nuclear Drosha, exported to the cytoplasm by exportin V, and cleaved into their mature forms by the Dicer/Argonaute complex (Chang and Mendell, 2007). The Dicer complex allows miRNA to recognize target $m R N A$ by base-pairing with sequences in the 3 ' untranslated regions of the mRNAs. Complementary base-pairing results in target mRNA degradation, whereas incomplete base-pairing results in target mRNA translational repression by physical inhibition of the mRNA ribosomal protein translational machinery (Kloosterman and Plasterk, 2006). A single miRNA can interact with and affect translation of hundreds of target mRNAs, thus potentially producing dramatic effects on cellular
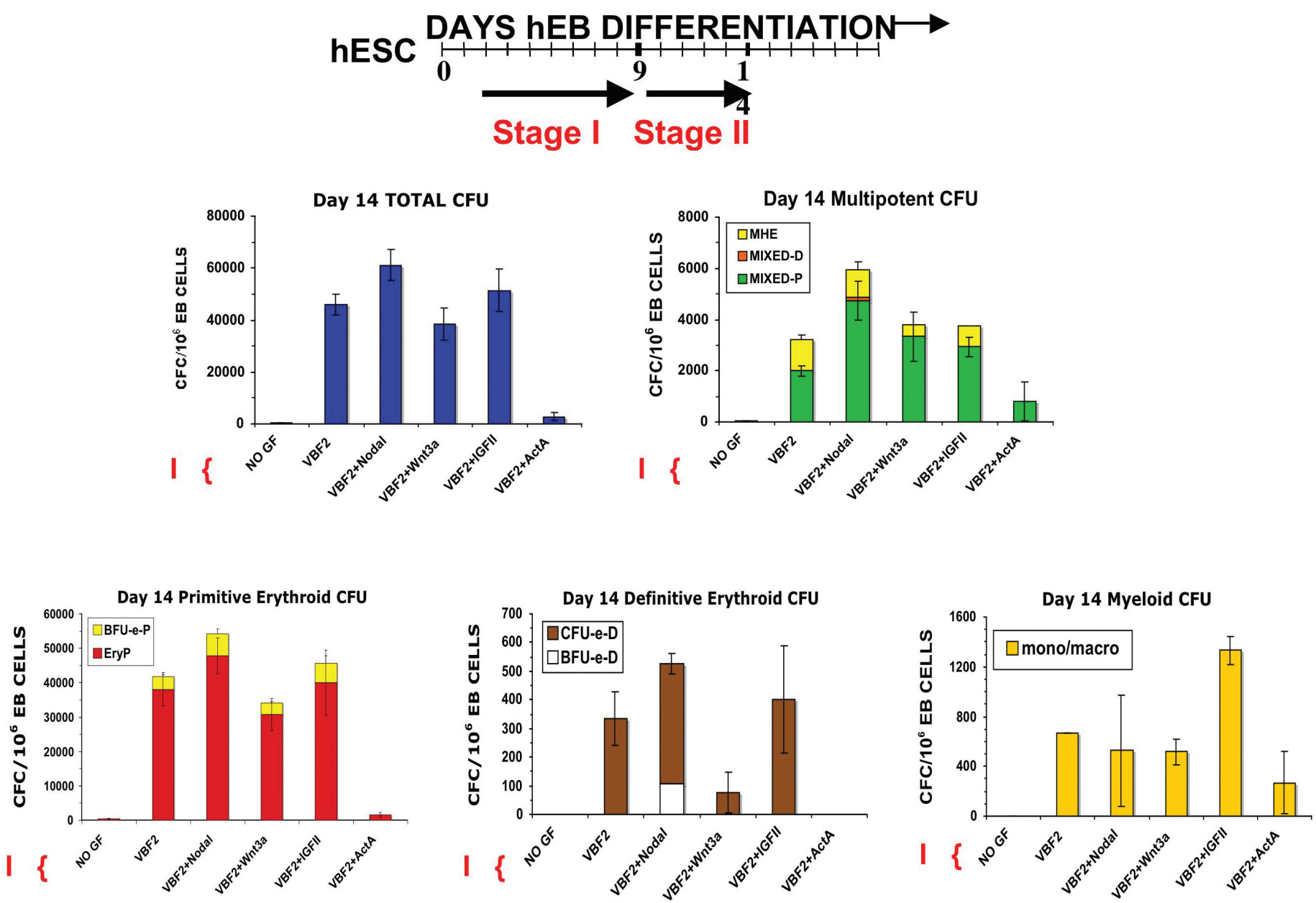

Fig. 4. Mesodermal morphogens and hematopoietic growth factors mediate agonistic and antagonistic effects on hEB hematopoietic differentiation potential. Line 1 (WA01) hEB were cultured in non-adherent serum-free (SF) suspension cultures in the presence of absence of VEGF, BMP4, and FGF2 (VBF2) starting on day 2 until day 9 (Stage I). On day 9, hEB were recultured as single cells onto gelatinized tissue culture plates in SF medium and supplemented with $50 \mathrm{ng} / \mathrm{ml}$ of the inductive or inhibitory hematopoietic growth factors Nodal, Wnt3a, IGFll, or Activin A (ActA) for 5 days (Stage II). Single cell suspensions of Day 14 hEB were evaluated for Colony-Forming-Cell (CFC) potential in serumfree H4436 SF methylcellulose containing hematopoietic growth factors. Total CFU, mutipotent CFU (MHE, Mixed-P, and Mixed-D), primitive erythroid (BFU-e-P, EryP), definitive erythroid (CFU-e-D, BFu-e-D), and myeloid (macrophage/monocyte) CFU formation was recorded. In comparison to basal VBF2, further addition of Nodal, a mesoderm inducer, enhanced the generation of all CFC except monocyte/macrophage CFU. Wnt3a, a downstream effector of Nodal, acted as a moderate agonist during mutlipotent CFU formation, but drastically reduced definitive erythropoiesis. IGFIl, another key player in mesodermal differentiation, moderately augmented multipotent CFU and primitive and definitive erythropoiesis. On the other hand, Activin A (ActA) dramacially abolished hematopoietic CFU. 
expression and in a tissue-specific manner (Lim et al., 2005; Chang and Mendell, 2007; Landgraf et al., 2007).

MiRNAs have also recently been shown to play a crucial role in nuclear reprogramming (Lin et al., 2008), and normal ESC selfrenewal and differentiation (Houbaviy et al., 2003; Suh et al., 2004; Wang et al., 2007). In particular, key pluripotency-associated transcription factors bind to promoters and enhance transcription of miRNA preferentially expressed in ESC while silencing miRNA genes upregulated in differentiating cells (Marson et al., 2008). Moreover, miRNAs are believed to orchestrate the developmental timing of cellular differentiation (Giraldez et al., 2005; Brown et al., 2007; Chang and Mendell, 2007; Martello et al., 2007; Neilson et al., 2007), including hematopoietic lineage specification (Chen et al., 2004; Felli et al., 2005; Costinean et al., 2006; Garzon et al., 2006; Ramkissoon et al., 2006; Bruchova et al., 2007; Choong et al., 2007; Fontana et al., 2007; Georgantas et al., 2007; Thai et al., 2007; Xiao et al., 2007; Zhan et al., 2007). For example, regulation of $H O X$ genes is regulated by several miRNAs (Yekta et al., 2004). Aberrant miRNA expression has also been established as an important pathway of tumorigenesis, including in hematopoietic and germ cell malignancies (Eis et al., 2005; Voorhoeve et al., 2006). In mice, several hematopoieticspecific miRNAs have been reported, including mir-223, mir-142, and mir-181 (Chen et al., 2004). Additionally, ectopic expression of mir-155 in adult murine hematopoietic progenitors results in profound effects on lymphopoietic function (Thai et al., 2007). In human $\mathrm{CD}^{+} 4^{+}$cells, down-regulation of miRNA 221 and 222 occurs during erythropoietic differentiation (Felli et al., 2005).

Several groups have shown that miRNAs may play instructive roles in mesodermal commitment of the embryo by directly controlling Noda/expression (Martello et al., 2007), which plays a pivotal role in the induction and patterning of mesoderm, as reviewed above. MiRNA regulation in epithelial to mesenchymal transition, which is key in gastrulation, has also been identified (Gregory et al., 2008). In hESCs, two miRNAs, miR-1 and miR133 , have been demonstrated to promote mesoderm formation by repressing non-muscle genes but have opposing functions in subsequent differentiation to cardiac progenitors (Ivey et al., 2008).

Although miRNAs clearly regulate developmental decisions, the regulatory role of miRNAs during normal human embryonic development of HSC is currently impossible to study, and the hESC differentiation system provides a valuable system for understanding their function. The miRNA signature of human hemangioblasts and HSC has not yet been reported. A clear role for miRNAs in hemangioblast development and differentiation should enlighten the developmental role of miRNAs in specifying the hematopoietic lineage. Furthermore, the ectopic expression of miRNAs acting as mimics (Voorhoeve etal., 2006) or antagomirs (anti-sense miRNA oligonucleotides) (Krutzfeldt et al., 2005) may augment or efficiently direct differentiation of hESC to mesodermal-hematopoietic lineages.

\section{The utility of hESC-derived hemangioblasts for gener- ating therapeutically-useful hematopoietic lineages}

Understanding and mimicking the in vivostem cell niches that generate hemangioblasts during development, as outlined above, may eventually allow powerful methodologies for generating therapeutically useful, patient-specific hemangioblasts from hESC/ iPSC. In vitro hemangioblast differentiation may provide unique opportunities for regenerative medicine by generating transplantable endothelial cells, HSC, megakaryocytes, lymphocytes, and transfusable granulocytes and erythrocytes (Olsen et al., 2006). Endothelial progenitor cells (EPCs), in particular, have received increased attention in recent years as the number of adults affected by cardiovascular diseases continues to rise (Rosamond et al., 2008). Researchers and clinicians hope to use EPCs to repair ischemic tissues, enhance blood vessels and heart valves that could replace the need for coronary angioplasty or coronary artery bypass graft surgery, which are currently used to repair damaged circulatory tissue (Niklason, 1999; Liew et al., 2006). The derivation of patient-specific transfusable erythrocytes, lymphocytes, and platelet-forming progenitors (megakaryocytes) from pluripotent stem cells would also have enormous utility. However, the derivation of all these therapeutically important lineages from human pluripotent stem cells currently all face unique technical challenges.

Efficient generation of hESC-derived B- and T-lymphocytes, for example, could play an important role in replenishing the immune system of patients suffering from severe combined immunodeficiency or AIDS. Although they are derived from a common progenitor, B- and T-lymphocytes develop in distinct sites in vivo and pose unique challenges in deriving them from $\mathrm{hESC}$. By recapitulating their in vivo development within the bone marrow, for example, the growth of CD45R+CD19+ mature functional $B$ cells from both mESCs and hESCs has been achieved (Cho et al., 1999; Cho and Zuniga-Pflucker, 2003) via co-culture on bone marrow stromal cell lines such as S17, MS5, and OP9 (Collins and Dorshkind, 1987; Landreth and Dorshkind, 1988; Itoh et al., 1989; Cumano et al., 1990). The addition of FLT3L and IL7 are crucial for this system's efficient production of B lymphocytes, although other cytokines, such as IL-4, have also been shown to augment this process.

Cord blood (CB), fetal liver, bone marrow (BM), and peripheral blood $\mathrm{CD} 34^{+}$cells have all been shown to be capable of generating $\mathrm{T}$ cells in vitro. Various methodologies, including the use of thymic stroma, have been described toward this end (Hare et al., 1999; Plum et al., 2000; LA MOTTE-MOHS et al., 2007). Clustering of human $\mathrm{CD} 34^{+} \mathrm{CB}$ cells with murine fetal thymic epithelial cells in reaggregated thymic organ cultures (RTOC) implanted into NOD/SCID mice gave rise to $\mathrm{CD} 4^{+} \mathrm{CD} 8^{+}$immature double positive (DP) as well as some functionally mature $\mathrm{CD}^{+}$and $\mathrm{CD}^{+}$ single positive (SP) T-cells (Saito et al., 2002). Murine thymic stromal cells have been used to seed matrices in a tissueengineering approach to produce $\mathrm{T}$ cells from human bone marrow derived hematopoietic progenitors (Poznansky et al., 2000). Thymic stromal culture from rhesus macaques has also been used for coculture with human CD34+ BM derived progenitor cells (Rosenzweig et al., 1996). Fetal thymic organ culture (FTOC), in which human HPC are cocultured with fetal thymic lobes from NOD-SCID mice, is a favored approach which, like all these systems, is useful but produces only a very limited number of T cells (Jenkinson and Anderson, 1994; Tavian et al., 2001).

In vitro production of T-cells from ESC, however, has been more challenging due to difficulties in recreating the unique thymic microenvironment (which plays a central role in the sequential, temporal, and spatial in vivodevelopment of these cells) 
which guides primitive HSC toward T-cell differentiation. The discovery of the key role of Notch-Delta signaling in the thymic stromal environment of the developing T cell led to the advent of the OP9-DL1 ESC co-culture system. The ability of the OP9-DL1 system to expand and maintain progenitor $T$ cells allows it to be uniquely utilized for large-scale generation of human $T$ cells from various sources. OP9-DL1 cells support the generation of DP immature T cells, as well as some $\mathrm{CD}^{+} \mathrm{SP}$ (but not as many CD4 ${ }^{+}$) cells from mouse HSC or differentiating mESC (from KDR/flk-1 populations, which contain murine hemangioblasts). The system has also been used successfully with human $C D 34^{+} \mathrm{CB}$ and bone marrow HSC (Schmitt and Zuniga-Pflucker, 2002; Schmitt et al., 2004; La Motte-Mohs et al., 2005). Recent attempts to generate lymphocytes from hESC-derived hematopoietic progenitor cells using both the OP9-DL1 co-culture system as well as FTOC have met with limited success (Martin et al., 2008). Since definitive HSC with lymphoid potential have been detected only from human AGM, and not YS embryonic tissues (Tavian et al., 2001), these results are not entirely surprising. They do, nonetheless, further highlight the necessity for methods that can generate adult-type definitive HSC from hESC before large-scale production of $\mathrm{T}$ cells for cell therapy will be possible.

One of the most promising applications of hESC hematopoietic differentiation technology is the efficient large-scale production of red blood cells (RBC) for clinical transfusion (Olivier et al., 2006). hESC-derived erythroid progenitors, which we and others have demonstrated can arise directly from $\mathrm{hESC}$-derived hemangioblasts, may provide a clinically useful and standardized source of transplantable RBC for urgent surgeries, or for treatment of hemoglobinopathies such as sickle cell disease and alpha/beta thalassemias. In general, a simple transfusion requires $\sim 1-2.5 \times 10^{12}$ red blood cells $\left(500 \mathrm{ml}\right.$ of whole blood at $5 \times 10^{9}$ red blood cells per $\mathrm{ml}$ ) (Ma et al., 2008b). Since blood donations are often in short supply, a blood bank with hESC-derived erythroid progenitor cells (for example

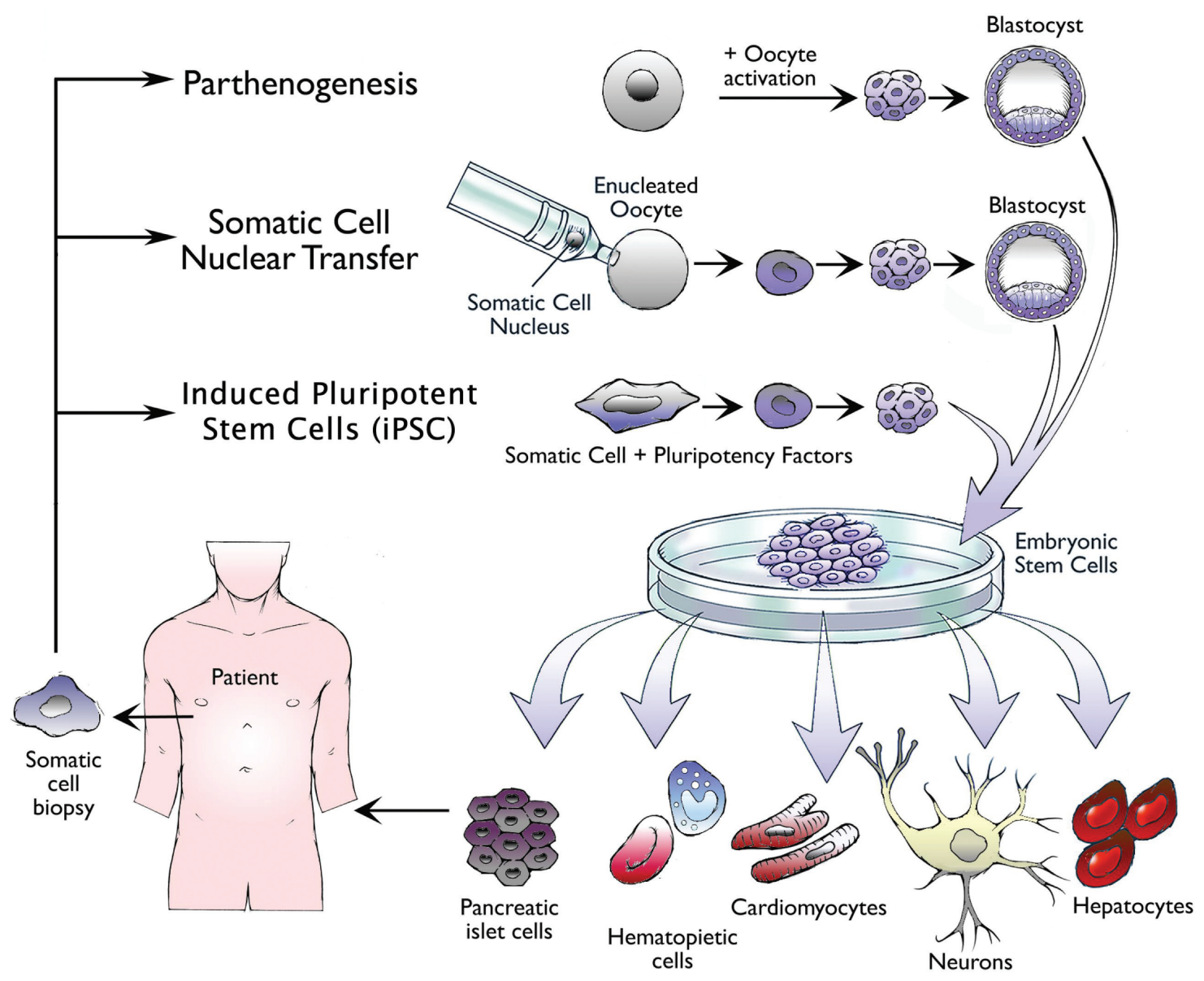

Fig. 5. Methods for generating autologous, patient-specific pluripotent stem cells for therapeutic cell transplantation. Parthenogenesis (PG), somatic cell nuclear transfer (SCNT), and induced pluripotent stem cells (iPSC) have been proposed as the three technologies by which patient-specific pluripotent stem cells could be generated for the generation of transplantable patient-specific progenitors, including hemangioblasts. The process of $P G$ requires chemical activation of a patient's isolated oocyte to proceed to the blastocyst stage, at which point embryonic stem cells can be isolated for subsequent therapeutic generation of somatic cells. Comparatively, SCNT also requires the use of an oocyte, but in an enucleated state. Transfer of a patient's somatic cell nucleus into the cytoplasm of the nucleus, resets the engineered cell to a pluripotent state. Induced pluripotency reprograms a somatic cell into a pluripotent state in the absence of an oocyte or a blastocyst intermediate by genetically transmitting defined pluripotency factors that can reprogram somatic cells to an embryonic stem cell-like state. Pluripotent stem cells generated by any of these methods can be differentiated into all cell types of the body. Progenitor cells from various lineages (e.g. blood, pancreas, heart, neurons, and liver) generated from patient-specific pluripotent stem cells can be transplanted back into the donor as autologous cell grafts without fear of immune rejection. 
from a pluripotent line expressing the universal blood type $O$ antigen) may provide an unlimited source of transfusable erythrocytes. This goal would require hESC differentiation and subsequent mass production of erythroid cells expressing definitive-type fetal- or adult beta globin-expressing RBC, which has not yet been reported. Murine erythropoietic differentiation systems have thus far proven more successful in the massive production of definitive, transfusable RBC. mESC-derived erythroid progenitors (ES-EPs) with cell morphology, growth and terminal differentiation characteristics similar to those of immature erythroid progenitors found during in vivo stress erythropoiesis, were generated efficiently in the presence of Epo, SCF, and glucocorticoids (Carotta et al., 2004). ES-EPs (Ter119 ${ }^{+} \mathrm{CKit}^{+} \mathrm{CD} 71^{+}$erythroblasts) could be expanded for over 70 days, and terminally differentiated into enucleated erythrocytes. In a similar study, ES-EPs could ameliorate acute anemia upon injection into affected mice, suggesting that $E P$ from hESC could similarly function in anemic disorders (Hiroyama et al., 2008).

Recent reports have confirmed the feasibility of massively expanding enucleated, human RBC from hESC differentiated in suspension liquid cultures (e.g. $\sim 10^{9}-10^{11}$ erythrocytes from one six-well starting plate with $\sim 3 \times 10^{6}$ cells hESC) (Lu et al., 2008). In these studies, hEB-derived hemangioblasts were differentiated into mature, enucleated red blood cells with oxygen equilibrium, $\mathrm{pH}$ and 1,3-diphosphoglycerate depletion responses analogous to those of transfusable RBC. Although these erythroid cells expressed low levels of adult beta-globin ( $16 \%)$, and high levels of embryonic/fetal hemoglobins (thus indicating that they are sill at a YS-like developmental phase), this large-scale production could potentially be optimized for establishing and expanding erythroid progenitor lines with long-term proliferation capacity. Although enucleated fetal-type definitive erythroid cells expressing the universal blood group $\mathrm{O}$ were generated in these studies, before such methodologies could be used more practically for transfusions in clinical or medical research, efficient protocols for the derivation of more mature adult type, beta-globin-expressing RBC will need to be developed (as they have been for CB CD34+ cells (NeildezNguyen etal., 2002; Giarratana etal., 2005; Miharada et al., 2006). The generation of such adult-type RBC from ESC has generally depended on the recapitulation of the in vivo microenvironment found in the FL and BM using cytokines, growth factors, and stromal cells. For example, liquid culture of hESC-derived CD34 ${ }^{+}$ cells in the presence of IL-3, BMP4, FLT3L, SCF and EPO in a stage-specific manner during hematopoietic differentiation, and subsequent co-culture on MS-5 feeder layers resulted in the formation of megaloblastic, nucleated erythroid cells (Olivier et al., 2006). These cultures initially formed pro- and basophilic erythroblasts expressing embryonic Gower I $\left(\zeta_{2} \varepsilon_{2}\right)$ and Gower II $\left(\alpha_{2} \mu_{2}\right)$. In another system, co-culture of hESC-derived CD34 ${ }^{+}$cells on immortalized fetal liver stroma resulted in similar erythroblast generation with expression of embryonic hemoglobins (Qiu et al., 2008). Extended culture to 35 days produced enucleated erythrocytes with hemoglobin switching to fetal hemoglobins $\left(\alpha_{2} \varepsilon_{2}\right)$, and minimal $(\sim 2 \%)$ adult $\beta$-hemoglobin expression. In contrast, formation of definitive erythroid colonies, bursts, and mixed colonies from $\mathrm{hESC}$ was recently described using a mouse fetal liver stromal cell co-culture system (Ma et al., 2008a). CFC assays at various developing timepoints from these co-cultures revealed erythrocytes with rapidly increasing beta-globin expression (from $26 \%$ to $\sim 100 \%$ ), and decreasing epsilon-globin expressions (from 100\% to $50 \%$ ). Comparison of hESC-derived erythroid cells to definitive CB erythroid cells confirmed a similarity in their G6PD and oxygen dissociation curves. These studies collectively demonstrate that transplantable adult-type RBC expressing adult hemoglobins could eventually be produced on a large scale from human pluripotent stem cells.

Mass production of platelets using hESC derived-megakaryocytes (the platelet producing cell of the human body) could alleviate the need for donors and allow the production of unlimited supplies for treating the thrombocytopenia of chronic chemotherapy, or from blood clotting disorders (e.g., Bernard-Souliér syndrome and Glanzmann thrombasthenia). The OP9 stromal system may be useful for generating hESC-derived, functional megakaryocytes. Several groups have already shown that ESC can readily be induced to differentiate into such megakaryocytic progenitors using TPO and OP9 stroma to give rise to functional cells secreting proplatelets and fibrinogen after exposure to platelet agonists (Era et al., 2000; Eto et al., 2002; Eto et al., 2003; Fujimoto et al., 2003)

Furthermore, mass production of transfusable granulocytes could also supplement host-deficient neutrophil production in congenital leukocyte function deficiencies, or chemotherapy-induced myelosuppression (Saeki et al., 2008). 75\% efficient neutrophil production from mESC was first accomplished using a 3-step differentiation protocol. In this system, formation of mEBs (8 days) followed by sequential co-culture of mEBs on OP9 stroma in medium containing a broad cocktail of hematopoietic growth factors, resulted in the production of $10^{7}$ neutrophils from 80,000 mESC (Lieber et al., 2003; Lieber et al., 2004). Differentiation of hESC into neutrophils was similarly accomplished using a 2-step feeder-free hEB-based differentiation method supplemented with hematopoietic growth factors (Saeki et al., 2008), albeit at much lower efficiencies ( $4 \times 10^{6}$ neutrophils from $\left.\sim 4 \times 10^{6} \mathrm{hESC}\right)$. These neutrophils expressed CD66b, CD16b, and GPI-80, had morphological and cytochemical (myeloperoxidase and neutrophil alkaline phosphatase) characteristics of mature neutrophils. hESC-derived granulocytes also exhibited neutrophil characteristics of chemotactic activity, chemoattractant stimulation, production of reactive oxygen species upon phagocytosis, and in vivo IL-1b-enhanced migration

\section{Patient-specific pluripotent stem cells can be gener- ated via various methods for the ultimate production of autologous hemangioblasts}

A crucial step that remains to be elucidated before hESC can become clinically useful for generating therapeutic hemangioblasts and HSC is the avoidance of the immune-mediated rejection that will result upon transfer of allogeneic, hESC-derived cells into recipients. The best way to circumvent this technical, yet critical caveat is to generate autologous, patient-specific pluripotent stem cells that could subsequently be used for generating HSC. Currently, three methodologies have been proposed to generate patient-specific pluripotent cells: 1) parthenogenesis (PG), 2) somatic cell nuclear transfer (SCNT), and 3) induced pluripotent stem cells (iPSC) (Fig. 5).

\section{Parthenogenesis (PG)}

This alternative asexual reproductive mechanism, which oc- 
curs in insects and reptiles, can be exploited experimentally to produce a diploid embryo from an unfertilized, artificially-activated oocyte (Cibelli et al., 2002; Cibelli et al., 2006). In mammals, PG-derived embryos arrest at the limb bud stage due to the lack of essential paternal genomic imprinting of critical genes required for proper development (Kono et al., 1996). Although limited in their potential to undergo complete organogenesis, PG-derived pre-implantation embryos at the blastocyst stage represent a valuable source of parthenogenetic ESC (pgESC) for research purposes. These embryos can be used to produce pgESC lines that are substantially (but not completely) genetically identical to the oocyte donor. Experimentally, oocytes can retain diploidy via retention of a polar body using cytokinesis inhibitors and calcium ionophores (Revazova et al., 2007; Revazova et al., 2008), or rarely via spontaneous duplication of the haploid genome during subsequent development. pgESC from mice, monkeys, and humans have been shown to retain characteristics of ESC including the ability to self-renew, to contribute to chimeric animals, and to give rise to all three germ layers, including hematopoietic mesoderm (Kaufman etal., 1983; Cibelli et al., 2002; Vrana et al., 2003; Eckardt et al., 2007; Kim et al., 2007).

Since PG embryos are inherently defective in developing to full term, human PG-derived hESC (pg-hESC) from donated oocytes arguably avoid many of the ethical and political hurdles associated with the derivation of new hESC lines. Because PG embryos are derived from an artificially activated oocyte in the absence of sperm, the resulting embryo and pg-hESC line derived from it are remarkably similar to the oocyte donor, with a few exceptions in distal loci from the centromeres where crossing-over occurred during meiosis I. It has been shown that pg-hESC are as much as $90 \%$ identical, including all human leukocyte antigens (HLA) loci, thus representing a source of autologous transplantable cells for female oocyte donors, as well as their offspring. The derivation of pg-hESC with both heterozygous and homozygous HLA alleles has recently been shown (Kim et al., 2007; Lin et al., 2007; Mai et al., 2007; Revazova et al., 2007; Revazova et al., 2008). Thus, autologous transplantable cells from pg-hESC have become are a potential resource for therapeutic strategies for a number of diseases, including blood disorders.

HLA-homozygous genomes generated via PG will result in only three HLA markers for tissue transplantation matching, in contrast to six HLA markers in heterozygous diploid genomes. This has resulted in the proposal for the creation of a universal pghESC stem cell that may ultimately serve the transplantation needs of large populations. Computational models have predicted that a small number of such pg-hESC lines could provide a beneficial match for the majority of the population (Taylor et al., 2005). A stem cell bank could include HLA-homozygous pg-hESC lines, but also HLA-homozygous human adult fibroblast cells (for the generation of iPSC; see below) derived from donors previously tested for a desired haplotype through the National Marrow Donor Program. However, such banks will not be suitable for minority populations such as African-Americans (primarily affected by sickle cell anemia), or other ethnic minorities (e.g. affected by beta-thalassemia) with rare haplotypes.

However, the scarce availability of human oocytes, makes PG technically unpractical, although PG embryos could potentially be generated from surplus mature metaphase II oocytes donated in rare numbers as a by-product of in vitrofertilization (IVF). Alterna- tively, pg-hESC could also be derived from excess immature germinal vesicle and metaphase I oocytes, which are not suitable for reproductive technologies such as intracytoplasmic sperm injection or IVF. Frozen, surplus oocytes, which are voluntarily donated by couples routinely for research, could also potentially be utilized (Polak et al., 2007). Overall, other alternative methods will likely ultimately prove more practical than $\mathrm{pG}$ for generating autologous hESC for patients.

\section{Somatic cell nuclear transfer (SCNT)}

SCNT, which was first described sixty years ago by Briggs and King in classic frog developmental studies, demonstrated that somatic cell nuclei transferred to enucleated oocytes can be reprogrammed back into a pluripotent state, indicating that somatic differentiation is a reversible process (Briggs and King, 1952). During the SCNT process, nuclei extracted from adult somatic cells (e.g., fibroblasts) can reactivate pluripotency genes that were previously silenced during cellular specification and differentiation following exposure to oocyte cytoplasmic factors. Subsequent culture of these artificially-activated pseudo-zygotes leads to the formation of a blastocyst, from which an inner cell mass can be isolated to generate ESC that are genetically identical to the donor of the somatic cell nucleus.

SCNT has now been demonstrated in a number of mammals since a cloned sheep ("Dolly") was first reported (Campbell et al., 1996). Although SCNT has a long history, it was only recently demonstrated that SCNT-derived ESC could be generated from nonhuman primates using adult male rhesus macaque fibroblasts as a donor nuclei source (Byrne et al., 2007). Although these studies open avenues for generating patient-specific SCNTderived hESC for therapeutic cell therapies, a goal that yet remains to be achieved, SCNT inefficiency $(<1 \%$ in monkeys compared to $16 \%$ in parthenogenesis) requires a large number of oocytes for this technique to be clinically applicable. Additionally, SCNT requires costly and complex equipment making therapeutic cloning via SCNT an unlikely source to generate autologous patient-specific hESC in the near future.

\section{Induced pluripotent stem cells (iPSC)}

The technical and ethical challenges associated with deriving hESC using SCNT and PG have sparked alternative efforts for generating autologous pluripotent stem cells. One of the most promising approaches has been the emergence of geneticallyinduced pluripotency. During this process, somatic cells can be reprogrammed to a pluripotent-like state using defined groups of retrovirally-expressed pluripotency-associated transcription factors (e.g., SOX2, OCT-3/4, KLF4, C-MYC, LIN28, and NANOG; SOKMLN), as first demonstrated by Takahashi and Yamanaka using murine embryonic fibroblasts and SOKM (Takahashi and Yamanaka, 2006; Okita et al., 2007; Takahashi et al., 2007a). These iPSC readily form multi-lineage teratomas in NOD/SCID immunodeficient hosts, and contribute efficiently to the development of fertile chimeric mice, thus demonstrating comparability to bona fide ESC derived from blastocysts.

This methodology quickly translated to human somatic cells including fibroblasts, MSC, and keratinocytes, resulting in the first human iPSC, albeit at significantly lower frequencies than in murine cells (Takahashi et al., 2007b; Yu et al., 2007; Nakagawa et al., 2008; Park et al., 2008b). Derivation of iPSC lines from 
patients' diseased somatic cells has recently confirmed the feasibility of generating autologous iPSC lines for transplantation purposes and disease modeling. Several diseased iPSC lines have already been generated, including ones affected with Down syndrome, Parkinson's disease, Huntington's disease, and Shwachman-Bodian-Diamond syndrome (Park et al., 2008a). Diseased iPSC have also been derived from fibroblasts of an $82-$ year-old woman diagnosed with amyotrophic lateral sclerosis. These iPSC could successfully be differentiated into motor neurons, which are destroyed in ALS (Dimos et al., 2008).

Although the generation of patient-specific iPSC appears to resolve the problem of immune rejection, a major problem in this technology is the serious potential for malignant transformation of these pluripotent lines. This risk is considerable with the current use of retro- and lentiviruses, since such vectors are prone to random insertional mutagenesis. In particular, the use of the proto-oncogenes KLF4 and C-MYC in current iPSC cocktails is problematic, since they have known potentials for malignant transformation. Indeed, chimeric mice made with iPSC that were generated using these pluripotency factors as transgenes eventually formed malignant tumors (Nakagawa et al., 2008). The oncogenicity of iPSC can be reduced by using only OCT4, and either KLF4 or C-MYC (Kim et al., 2008), or alternatively OCT4 and SOX2 transgenes alone, thus avoiding KLF4 and C-MYC altogether (Huangfu et al., 2008b), but insertional mutagenic potential inherent in the use of retroviral constructs will still remain a grave concern for ultimate clinical utility (Hacein-Bey-Abina et al., 2003; McCormack and Rabbitts, 2004).

Recently published studies have already begun to address the caveats of iPSC derived by first-generation methods. Using CreLoxP excisable lentiviral and transposon-inserted transgenes, recent studies have demonstrated that persistent viral-integrated transgene expression is not required for reprogramming somatic cells, and that vector-free iPSC can be generated, albeit at lower efficiencies (Soldner et al., 2009; Woltjen et al., 2009). Additionally, generation of human iPSC using nonintegrating constructs was also recently reported (e.g., using recombinant adenoviruses (Stadtfeld et al., 2008), Epstein-Barr virus-based episomal constructs (Yu et al., 2009), SOKM proteins fused with cell penetrating peptides (CPPs) (Kim et al., 2009; Zhou et al., 2009), or repeated transfections of plasmids harboring SOKM cDNAs (Okita etal., 2008)), thus confirming that reprogramming does not rely on genomic integration or insertional mutagenesis. Although this field is now rapidly progressing and holds great potential for ultimately producing clinically safe iPSC, methodologies for further optimizing the currently low reprogramming process will still need to be developed (Huangfu et al., 2008a).

\section{Future Directions}

Although the existence of the hemangioblast was first recognized almost a century ago (Sabin, 1920; Murray, 1932), in vitro strategies for isolating, characterizing, or generating human hemangioblasts, and adult-type, definitive hematopoietic cell lineages from them, has thus far been elusive. The recent isolation and characterization of the human hemangioblast from hESC has created new potential to further evaluate mechanisms by which hemangioblasts and HSC could be generated, maintained, and expanded. It has become apparent that complex in vivo developmental signaling pathways and environments will need to be recapitulated to further mature these hESC-derived primitive progenitors into adult blood cells before they can be practically used in regenerative medicine for a number of hematological diseases.

Moreover, before hESC-derived hemangioblast and HSC can be used for clinical applications, patient-specific pluripotent stem cells will first need to be generated with more efficient, and ethically non-controversial methodologies than the current approaches that PG or SCNT provide. Human iPSC, which solve some of these obstacles, will have to be generated via methods that lack malignant potential, as was recently described using nonintegrating episomal vectors (Okita et al., 2008; Stadtfeld et al., 2008; Yu et al., 2009) or reprogramming proteins fused with CPPs (Kim et al., 2009; Zhou et al., 2009). Moreover, despite their great similarities to hESC, it remains to be seen whether iPSC will hold comparable, or perhaps even greater differentiating potential than hESC for generating hematopoietic lineages (Choi et al., 2009; Loh etal., 2009). Finally, the differentiation of hemangioblasts and HSC from diseased patient-specific iPSC will shed important biologic insight into the developmental pathways and molecular nature of a number of hematologic disorders.

\section{Acknowledgements}

We thank Alan Friedman, Linda Resar, and Matt Porteus for helpful comments on this manuscript. This work was funded by grants from the Maryland Stem Cell Research Fund (ETZ, MVP), The Johns Hopkins Institute of Cell Engineering (ETZ), and the National Institutes of Health (ETZ)

\section{References}

ABRAMOVICH, C. and HUMPHRIES, R. K. (2005). Hox regulation of normal and leukemic hematopoietic stem cells. Curr.Opin.Hematol. 3: 210-216.

ADAMS, G. B., CHABNER, K. T., ALLEY, I. R., OLSON, D. P., SZCZEPIORKOWSKI, Z. M., POZNANSKY, M. C., KOS, C. H., POLLAK, M. R., BROWN, E. M. and SCADDEN, D. T. (2006). Stem cell engraftment at the endosteal niche is specified by the calcium-sensing receptor. Nature 7076: 599-603.

ADELMAN, C. A., CHATTOPADHYAY, S. and BIEKER, J. J. (2002). The BMP/ BMPR/Smad pathway directs expression of the erythroid-specific EKLF and GATA1 transcription factors during embryoid body differentiation in serum-free media. Development 2: 539-549.

AKISHITA, M., ITO, M., LEHTONEN, J. Y., DAVIET, L., DZAU, V. J. and HORIUCHI, M. (1999). Expression of the AT2 receptor developmentally programs extracellular signal-regulated kinase activity and influences fetal vascular growth. J.Clin. Invest. 1: 63-71

ANG, S. L. and CONSTAM, D. B. (2004). A gene network establishing polarity in the early mouse embryo. Semin.Cel/ Dev.Biol. 5: 555-561.

ANGELOPOULOU, M., NOVELLI, E., GROVE, J. E., RINDER, H. M., CIVIN, C., CHENG, L. and KRAUSE, D. S. (2003). Cotransplantation of human mesenchymal stem cells enhances human myelopoiesis and megakaryocytopoiesis in NOD/SCID mice. Exp. Hematol. 5: 413-420.

ANTONCHUK, J., SAUVAGEAU, G. and HUMPHRIES, R. K. (2002). HOXB4induced expansion of adult hematopoietic stem cells ex vivo. Ce//1: 39-45.

ARAI, F., HIRAO, A., OHMURA, M., SATO, H., MATSUOKA, S., TAKUBO, K., ITO, K., KOH, G. Y. and SUDA, T. (2004). Tie2/angiopoietin-1 signaling regulates hematopoietic stem cell quiescence in the bone marrow niche. Cel/2: 149-161.

ARIIZUMI, T., SAWAMURA, K., UCHIYAMA, H. and ASASHIMA, M. (1991). Dose and time-dependent mesoderm induction and outgrowth formation by activin $A$ in Xenopus laevis. Int.J.Dev.Biol. 4: 407-414

AYTON, P. M. and CLEARY, M. L. (2003). Transformation of myeloid progenitors by MLL oncoproteins is dependent on Hoxa7 and Hoxa9. Genes Dev. 18: 2298 2307. 
BANSAL, D., SCHOLL, C., FROHLING, S., MCDOWELL, E., LEE, B. H., DOHNER, K., ERNST, P., DAVIDSON, A. J., DALEY, G. Q., ZON, L. I., GILLILAND, D. G. and HUNTLY, B. J. (2006). Cdx4 dysregulates Hox gene expression and generates acute myeloid leukemia alone and in cooperation with Meis1a in a murine model. Proc.Nat..Acad. Sci.USA 45: 16924-16929.

BARON, M. (2001). Induction of embryonic hematopoietic and endothelial stem/ progenitor cells by hedgehog-mediated signals. Differentiation 4-5: 175-185.

BEATTIE, G. M., LOPEZ, A. D., BUCAY, N., HINTON, A., FIRPO, M. T., KING, C. C. and HAYEK, A. (2005). Activin A maintains pluripotency of human embryonic stem cells in the absence of feeder layers. Stem Cel/s 4: 489-495.

BECK, S., LE GOOD, J. A., GUZMAN, M., BEN HAIM, N., ROY, K., BEERMANN, F. and CONSTAM, D. B. (2002). Extraembryonic proteases regulate Nodal signalling during gastrulation. Nat.Cell Biol. 12: 981-985.

BEDDINGTON, R. S. and ROBERTSON, E. J. (1998). Anterior patterning in mouse. Trends Genet. 7: 277-284.

BELO, J. A., BOUWMEESTER, T., LEYNS, L., KERTESZ, N., GALLO, M., FOLLETTIE, M. and DE ROBERTIS, E. M. (1997). Cerberus-like is a secreted factor with neutralizing activity expressed in the anterior primitive endoderm of the mouse gastrula. Mech.Dev. 1-2: 45-57.

BEN-HAIM, N., LU, C., GUZMAN-AYALA, M., PESCATORE, L., MESNARD, D., BISCHOFBERGER, M., NAEF, F., ROBERTSON, E. J. and CONSTAM, D. B. (2006). The nodal precursor acting via activin receptors induces mesoderm by maintaining a source of its convertases and BMP4. Dev. Cell. 3: 313-323.

BENSIDHOUM, M., CHAPEL, A., FRANCOIS, S., DEMARQUAY, C., MAZURIER, C., FOUILLARD, L., BOUCHET, S., BERTHO, J. M., GOURMELON, P., AIGUEPERSE, J., CHARBORD, P., GORIN, N. C., THIERRY, D. and LOPEZ, M. (2004). Homing of in vitroexpanded Stro-1- or Stro-1+ human mesenchymal stem cells into the NOD/SCID mouse and their role in supporting human CD34 cell engraftment. Blood9: 3313-3319.

BHATIA, M., BONNET, D., WU, D., MURDOCH, B., WRANA, J., GALLACHER, L. and DICK, J. E. (1999). Bone morphogenetic proteins regulate the developmental program of human hematopoietic stem cells. J.Exp.Med. 7: 1139-1148.

BLAZSEK, I., CHAGRAOUI, J. and PEAULT, B. (2000). Ontogenic emergence of the hematon, a morphogenetic stromal unit that supports multipotential hematopoietic progenitors in mouse bone marrow. Blood 12: 3763-3771.

BLUM, M., GAUNT, S. J., CHO, K. W., STEINBEISSER, H., BLUMBERG, B., BITTNER, D. and DE ROBERTIS, E. M. (1992). Gastrulation in the mouse: the role of the homeobox gene goosecoid. Cel/7: 1097-1106.

BRENNAN, J., LU, C. C., NORRIS, D. P., RODRIGUEZ, T. A., BEDDINGTON, R. S. and ROBERTSON, E. J. (2001). Nodal signalling in the epiblast patterns the early mouse embryo. Nature 6840: 965-969.

BRIGGS, R. and KING, T. J. (1952). Transplantation of Living Nuclei From Blastula Cells into Enucleated Frogs' Eggs. Proc. Natl. Acad. Sci. USA 5: 455-463.

BROWN, B. D., GENTNER, B., CANTORE, A., COLLEONI, S., AMENDOLA, M., ZINGALE, A., BACCARINI, A., LAZZARI, G., GALLI, C. and NALDINI, L. (2007). Endogenous microRNA can be broadly exploited to regulate transgene expression according to tissue, lineage and differentiation state. Nat.Biotechnol. 12: 1457-1467.

BRUCHOVA, H., YOON, D., AGARWAL, A. M., MENDELL, J. and PRCHAL, J. T. (2007). Regulated expression of microRNAs in normal and polycythemia vera erythropoiesis. Exp. Hematol. 11: 1657-1667.

BURDSAL, C. A., FLANNERY, M. L. and PEDERSEN, R. A. (1998). FGF-2 alters the fate of mouse epiblast from ectoderm to mesoderm in vitro. Dev.Biol. 2: 231244.

BURRIDGE, P. W., ANDERSON, D., PRIDDLE, H., BARBADILLO MUNOZ, M. D., CHAMBERLAIN, S., ALLEGRUCCI, C., YOUNG, L. E. and DENNING, C. (2007). Improved human embryonic stem cell embryoid body homogeneity and cardiomyocyte differentiation from a novel V-96 plate aggregation system highlights interline variability. Stem Cells 4: 929-938.

BYRD, N., BECKER, S., MAYE, P., NARASIMHAIAH, R., ST-JACQUES, B., ZHANG, X., MCMAHON, J., MCMAHON, A. and GRABEL, L. (2002). Hedgehog is required for murine yolk sac angiogenesis. Development 2: 361-372.

BYRNE, J. A., PEDERSEN, D. A., CLEPPER, L. L., NELSON, M., SANGER, W. G., GOKHALE, S., WOLF, D. P. and MITALIPOV, S. M. (2007). Producing primate embryonic stem cells by somatic cell nuclear transfer. Nature 7169: 497-502.

CALVI, L. M., ADAMS, G. B., WEIBRECHT, K. W., WEBER, J. M., OLSON, D. P.,
KNIGHT, M. C., MARTIN, R. P., SCHIPANI, E., DIVIETI, P., BRINGHURST, F. R., MILNER, L. A., KRONENBERG, H. M. and SCADDEN, D. T. (2003). Osteoblastic cells regulate the haematopoietic stem cell niche. Nature 6960 841-846

CAMPBELL, K. H., MCWHIR, J., RITCHIE, W. A. and WILMUT, I. (1996). Sheep cloned by nuclear transfer from a cultured cell line. Nature 6569: 64-66.

CAROTTA, S., PILAT, S., MAIRHOFER, A., SCHMIDT, U., DOLZNIG, H., STEINLEIN, P. and BEUG, H. (2004). Directed differentiation and mass cultivation of pure erythroid progenitors from mouse embryonic stem cells. Blood 6 : 1873-1880.

CARPENTER, M. K., ROSLER, E. and RAO, M. S. (2003). Characterization and differentiation of human embryonic stem cells. Cloning Stem Cells 1: 79-88.

CERDAN, C., ROULEAU, A. and BHATIA, M. (2004). VEGF-A165 augments erythropoietic development from human embryonic stem cells. Blood7: 25042512.

CHADWICK, K., WANG, L., LI, L., MENENDEZ, P., MURDOCH, B., ROULEAU, A and BHATIA, M. (2003). Cytokines and BMP-4 promote hematopoietic differentiation of human embryonic stem cells. Blood 3: 906-915.

CHANG, T. C. and MENDELL, J. T. (2007). microRNAs in vertebrate physiology and human disease. Annu.Rev. Genomics Hum. Genet.215-239.

CHARBORD, P., TAVIAN, M., HUMEAU, L. and PEAULT, B. (1996). Early ontogeny of the human marrow from long bones: an immunohistochemical study of hematopoiesis and its microenvironment. Blood 10: 4109-4119.

CHARITE, J., DE GRAAFF, W., CONSTEN, D., REIJNEN, M. J., KORVING, J. and DESCHAMPS, J. (1998). Transducing positional information to the Hox genes: critical interaction of cdx gene products with position-sensitive regulatory elements. Development 22: 4349-4358.

CHAWENGSAKSOPHAK, K., DE GRAAFF, W., ROSSANT, J., DESCHAMPS, J. and BECK, F. (2004). Cdx2 is essential for axial elongation in mouse development. Proc. Natl. Acad. Sci. USA 20: 7641-7645.

CHAWENGSAKSOPHAK, K., JAMES, R., HAMMOND, V. E., KONTGEN, F. and BECK, F. (1997). Homeosis and intestinal tumours in Cdx2 mutant mice. Nature 6620: 84-87.

CHEN, C. Z., LI, L., LODISH, H. F. and BARTEL, D. P. (2004). MicroRNAs modulate hematopoietic lineage differentiation. Science 5654: 83-86.

CHEN, W., LI, Q., HUDSON, W. A., KUMAR, A., KIRCHHOF, N. and KERSEY, J. H. (2006). A murine MII-AF4 knock-in model results in lymphoid and myeloid deregulation and hematologic malignancy. Blood2: 669-677.

CHO, S. K., WEBBER, T. D., CARLYLE, J. R., NAKANO, T., LEWIS, S. M. and ZUNIGA-PFLUCKER, J. C. (1999). Functional characterization of B lymphocytes generated in vitro from embryonic stem cells. Proc. Natt. Acad. Sci. USA 17: 9797-9802.

CHO, S. K. and ZUNIGA-PFLUCKER, J. C. (2003). Development of lymphoid lineages from embryonic stem cells in vitro. Methods Enzymol.158-169.

CHOI, K. D., YU, J., SMUGA-OTTO, K., SALVAGIOTTO, G., REHRAUER, W. VODYANIK, M., THOMSON, J. and SLUKVIN, I. (2009). Hematopoietic and endothelial differentiation of human induced pluripotent stem cells. Stem Cells 3: 559-567. (doi: 10.1634/stemcells.2008-0922).

CHOI, K., KENNEDY, M., KAZAROV, A., PAPADIMITRIOU, J. C. and KELLER, G. (1998). A common precursor for hematopoietic and endothelial cells. Development 4: 725-732.

CHOONG, M. L., YANG, H. H. and MCNIECE, I. (2007). MicroRNA expression profiling during human cord blood-derived CD34 cell erythropoiesis. Exp. Hematol. 4: 551-564.

CIBELLI, J. B., CUNNIFF, K. and VRANA, K. E. (2006). Embryonic stem cells from parthenotes. Methods Enzymol.117-135.

CIBELLI, J. B., GRANT, K. A., CHAPMAN, K. B., CUNNIFF, K., WORST, T., GREEN, H. L., WALKER, S. J., GUTIN, P. H., VILNER, L., TABAR, V., DOMINKO, T., KANE, J., WETTSTEIN, P. J., LANZA, R. P., STUDER, L., VRANA, K. E. and WEST, M. D. (2002). Parthenogenetic stem cells in nonhuman primates. Science 5556: 819.

CIRUNA, B. G. and ROSSANT, J. (1999). Expression of the T-box gene Eomesodermin during early mouse development. Mech.Dev. 1-2: 199-203.

COHN, R. D., VAN ERP, C., HABASHI, J. P., SOLEIMANI, A. A., KLEIN, E. C., LISI, M. T., GAMRADT, M., AP RHYS, C. M., HOLM, T. M., LOEYS, B. L., RAMIREZ, 
F., JUDGE, D. P., WARD, C. W. and DIETZ, H. C. (2007). Angiotensin II type 1 receptor blockade attenuates TGF-beta-induced failure of muscle regeneration in multiple myopathic states. Nat.Med. 2: 204-210.

COLLINS, L. S. and DORSHKIND, K. (1987). A stromal cell line from myeloid longterm bone marrow cultures can support myelopoiesis and B lymphopoiesis. J.Immunol. 4: 1082-1087.

CONLON, F. L., LYONS, K. M., TAKAESU, N., BARTH, K. S., KISPERT, A., HERRMANN, B. and ROBERTSON, E. J. (1994). A primary requirement for nodal in the formation and maintenance of the primitive streak in the mouse. Development 7: 1919-1928.

CORRAL, J., FORSTER, A., THOMPSON, S., LAMPERT, F., KANEKO, Y., SLATER, R., KROES, W. G., VAN DER SCHOOT, C. E., LUDWIG, W. D. and KARPAS, A. (1993). Acute leukemias of different lineages have similar MLL gene fusions encoding related chimeric proteins resulting from chromosomal translocation. Proc. Natl. Acad. Sci. USA 18: 8538-8542.

CORTES, F., DEBACKER, C., PEAULT, B. and LABASTIE, M. C. (1999). Differential expression of KDR/VEGFR-2 and CD34 during mesoderm development of the early human embryo. Mech.Dev. 1-2: 161-164.

COSTINEAN, S., ZANESI, N., PEKARSKY, Y., TILI, E., VOLINIA, S., HEEREMA, N. and CROCE, C. M. (2006). Pre-B cell proliferation and lymphoblastic leukemia/high-grade lymphoma in $\mathrm{E}(\mathrm{mu})-\mathrm{miR} 155$ transgenic mice. Proc. Natl. Acad. Sci. USA 18: 7024-7029.

COZZIO, A., PASSEGUE, E., AYTON, P. M., KARSUNKY, H., CLEARY, M. L. and WEISSMAN, I. L. (2003). Similar MLL-associated leukemias arising from selfrenewing stem cells and short-lived myeloid progenitors. Genes Dev. 24: 30293035 .

CROSSLEY, P. H. and MARTIN, G. R. (1995). The mouse Fgf8 gene encodes a family of polypeptides and is expressed in regions that direct outgrowth and patterning in the developing embryo. Development2: 439-451.

CUMANO, A., DORSHKIND, K., GILLIS, S. and PAIGE, C. J. (1990). The influence of $\mathrm{S} 17$ stromal cells and interleukin 7 on B cell development. Eur.J. Immunol. 10: 2183-2189.

CUMANO, A., FERRAZ, J. C., KLAINE, M., DI SANTO, J. P. and GODIN, I. (2001). Intraembryonic, but not yolk sac hematopoietic precursors, isolated before circulation, provide long-term multilineage reconstitution. Immunity 3: 477-485.

D'AMOUR, K. A., AGULNICK, A. D., ELIAZER, S., KELLY, O. G., KROON, E. and BAETGE, E. E. (2005). Efficient differentiation of human embryonic stem cells to definitive endoderm. Nat.Biotechnol. 12: 1534-1541.

DANDO, J. S., TAVIAN, M., CATELAIN, C., POIRAULT, S., BENNACEURGRISCELLI, A., SAINTENY, F., VAINCHENKER, W., PEAULT, B. and LAURET, E. (2005). Notch/Delta4 interaction in human embryonic liver CD34+ CD38cells: positive influence on BFU-E production and LTC-IC potential maintenance. Stem Cells 4: 550-560.

DAVIDSON, A. J., ERNST, P., WANG, Y., DEKENS, M. P., KINGSLEY, P. D., PALIS, J., KORSMEYER, S. J., DALEY, G. Q. and ZON, L. I. (2003). Cdx4 Mutants Fail to Specify Blood Progenitors and can be Rescued by Multiple Hox Genes. Nature 6955: 300-306.

DAVIDSON, A. J. and ZON, L. I. (2006). The caudal-related homeobox genes cdx1a and cdx4 act redundantly to regulate hox gene expression and the formation of putative hematopoietic stem cells during zebrafish embryogenesis. Dev.Biol. 2: 506-518.

DAVIES, S. M., SHU, X. O., BLAZAR, B. R., FILIPOVICH, A. H., KERSEY, J. H., KRIVIT, W., MCCULLOUGH, J., MILLER, W. J., RAMSAY, N. K. and SEGALL, M. (1995). Unrelated donor bone marrow transplantation: influence of HLA A and B incompatibility on outcome. Blood 4: 1636-1642.

DIMOS, J. T., RODOLFA, K. T., NIAKAN, K. K., WEISENTHAL, L. M., MITSUMOTO, H., CHUNG, W., CROFT, G. F., SAPHIER, G., LEIBEL, R., GOLAND, R., WICHTERLE, H., HENDERSON, C. E. and EGGAN, K. (2008). Induced pluripotent stem cells generated from patients with ALS can be differentiated into motor neurons. Science 5893: 1218-1221.

DOBSON, C. L., WARREN, A. J., PANNELL, R., FORSTER, A., LAVENIR, I., CORRAL, J., SMITH, A. J. and RABBITTS, T. H. (1999). The mll-AF9 gene fusion in mice controls myeloproliferation and specifies acute myeloid leukaemogenesis. EMBO J. 13: 3564-3574.

DYER, M. A., FARRINGTON, S. M., MOHN, D., MUNDAY, J. R. and BARON, M. $H$. (2001). Indian hedgehog activates hematopoiesis and vasculogenesis and can respecify prospective neurectodermal cell fate in the mouse embryo.
Development 10: 1717-1730.

ECKARDT, S., LEU, N. A., BRADLEY, H. L., KATO, H., BUNTING, K. D. and MCLAUGHLIN, K. J. (2007). Hematopoietic reconstitution with androgenetic and gynogenetic stem cells. Genes Dev. 4: 409-419.

EGAMI, K., MUROHARA, T., SHIMADA, T., SASAKI, K., SHINTANI, S., SUGAYA, T., ISHII, M., AKAGI, T., IKEDA, H., MATSUISHI, T. and IMAIZUMI, T. (2003). Role of host angiotensin II type 1 receptor in tumor angiogenesis and growth. J.Clin. Invest. 1: 67-75

EGUCHI, M., EGUCHI-ISHIMAE, M. and GREAVES, M. (2005). Molecular pathogenesis of MLL-associated leukemias. Int.J.Hematol. 1: 9-20.

EILKEN, H. M., NISHIKAWA, S. and SCHROEDER, T. (2009). Continuous singlecell imaging of blood generation from haemogenic endothelium. Nature 7231: 896-900.

EIS, P. S., TAM, W., SUN, L., CHADBURN, A., LI, Z., GOMEZ, M. F., LUND, E. and DAHLBERG, J. E. (2005). Accumulation of miR-155 and BIC RNA in human B cell lymphomas. Proc. Natl. Acad. Sci. USA 10: 3627-3632.

EMA, M., TAKAHASHI, S. and ROSSANT, J. (2006). Deletion of the selection cassette, but not cis-acting elements, in targeted Flk1-lacZ allele reveals Flk1 expression in multipotent mesodermal progenitors. Blood1: 111-117.

EPSTEIN, M., PILLEMER, G., YELIN, R., YISRAELI, J. K. and FAINSOD, A. (1997) Patterning of the embryo along the anterior-posterior axis: the role of the caudal genes. Development 19: 3805-3814.

ERA, T., TAKAGI, T., TAKAHASHI, T., BORIES, J. C. and NAKANO, T. (2000). Characterization of hematopoietic lineage-specific gene expression by ES cell in vitro differentiation induction system. Blood 3: 870-878.

ERNST, P., FISHER, J. K., AVERY, W., WADE, S., FOY, D. and KORSMEYER, S J. (2004a). Definitive hematopoiesis requires the mixed-lineage leukemia gene. Dev.Cell. 3: 437-443.

ERNST, P., MABON, M., DAVIDSON, A. J., ZON, L. I. and KORSMEYER, S. J. (2004b). An Mll-dependent Hox program drives hematopoietic progenitor expansion. Curr.Biol. 22: 2063-2069.

ETO, K., LEAVITT, A. L., NAKANO, T. and SHATTIL, S. J. (2003). Development and analysis of megakaryocytes from murine embryonic stem cells. Methods Enzymol.142-158.

ETO, K., MURPHY, R., KERRIGAN, S. W., BERTONI, A., STUHLMANN, H., NAKANO, T., LEAVITT, A. D. and SHATTIL, S. J. (2002). Megakaryocytes derived from embryonic stem cells implicate CalDAG-GEFl in integrin signaling. Proc. Natl. Acad. Sci. USA 20: 12819-12824.

FALOON, P., ARENTSON, E., KAZAROV, A., DENG, C. X., PORCHER, C., ORKIN, S. and CHOI, K. (2000). Basic fibroblast growth factor positively regulates hematopoietic development. Development 9: 1931-1941.

FEHLING, H. J., LACAUD, G., KUBO, A., KENNEDY, M., ROBERTSON, S., KELLER, G. and KOUSKOFF, V. (2003). Tracking mesoderm induction and its specification to the hemangioblast during embryonic stem cell differentiation. Development 17: 4217-4227.

FELLI, N., FONTANA, L., PELOSI, E., BOTTA, R., BONCI, D., FACCHIANO, F., LIUZZI, F., LULLI, V., MORSILLI, O., SANTORO, S., VALTIERI, M., CALIN, G. A., LIU, C. G., SORRENTINO, A., CROCE, C. M. and PESCHLE, C. (2005) MicroRNAs 221 and 222 inhibit normal erythropoiesis and erythroleukemic cell growth via kit receptor down-modulation. Proc. Natt. Acad. Sci. USA50: 18081 18086.

FERRANDO, A. A., ARMSTRONG, S. A., NEUBERG, D. S., SALLAN, S. E., SILVERMAN, L. B., KORSMEYER, S. J. and LOOK, A. T. (2003). Gene expression signatures in MLL-rearranged T-lineage and B-precursor acute leukemias: dominance of HOX dysregulation. Blood 1: 262-268.

FIDANZA, V., MELOTTI, P., YANO, T., NAKAMURA, T., BRADLEY, A., CANAANI, E., CALABRETTA, B. and CROCE, C. M. (1996). Double knockout of the ALL1 gene blocks hematopoietic differentiation in vitro. Cancer Res. 6: 1179-1183.

FONTANA, L., PELOSI, E., GRECO, P., RACANICCHI, S., TESTA, U., LIUZZI, F., CROCE, C. M., BRUNETTI, E., GRIGNANI, F. and PESCHLE, C. (2007). MicroRNAs 17-5p-20a-106a control monocytopoiesis through AML1 targeting and M-CSF receptor upregulation. Nat.Cel/ Biol. 7: 775-787.

FORSTER, A., PANNELL, R., DRYNAN, L. F., MCCORMACK, M., COLLINS, E. C. DASER, A. and RABBITTS, T. H. (2003). Engineering de novo reciprocal chromosomal translocations associated with Mll to replicate primary events of human cancer. Cancer.Cell. 5: 449-458. 
FRANCOIS, S., BENSIDHOUM, M., MOUISEDDINE, M., MAZURIER, C., ALLENET, B., SEMONT, A., FRICK, J., SACHE, A., BOUCHET, S., THIERRY, D. GOURMELON, P., GORIN, N. C. and CHAPEL, A. (2006). Local irradiation not only induces homing of human mesenchymal stem cells at exposed sites but promotes their widespread engraftment to multiple organs: a study of their quantitative distribution after irradiation damage. Stem Cel/s 4: 1020-1029.

FRIEDMAN, M. S., LONG, M. W. and HANKENSON, K. D. (2006). Osteogenic differentiation of human mesenchymal stem cells is regulated by bone morphogenetic protein-6. J.Cell.Biochem. 3: 538-554.

FUJIMOTO, T. T., KOHATA, S., SUZUKI, H., MIYAZAKI, H. and FUJIMURA, K. (2003). Production of functional platelets by differentiated embryonic stem (ES) cells in vitro. Blood 12: 4044-4051.

GAMER, L. W. and WRIGHT, C. V. (1993). Murine Cdx-4 bears striking similarities to the Drosophila caudal gene in its homeodomain sequence and early expression pattern. Mech.Dev. 1: 71-81.

GARZON, R., PICHIORRI, F., PALUMBO, T., IULIANO, R., CIMMINO, A., AQEILAN, R., VOLINIA, S., BHATT, D., ALDER, H., MARCUCCI, G., CALIN, G. A., LIU, C. G., BLOOMFIELD, C. D., ANDREEFF, M. and CROCE, C. M. (2006). MicroRNA fingerprints during human megakaryocytopoiesis. Proc. Natl. Acad. Sci. USA 13: $5078-5083$

GEORGANTAS, R. W.,3RD, HILDRETH, R., MORISOT, S., ALDER, J., LIU, C. G., HEIMFELD, S., CALIN, G. A., CROCE, C. M. and CIVIN, C. I. (2007). CD34+ hematopoietic stem-progenitor cell microRNA expression and function: a circuit diagram of differentiation control. Proc. Natl. Acad. Sci. USA 8: 2750-2755.

GIARRATANA, M. C., KOBARI, L., LAPILLONNE, H., CHALMERS, D., KIGER, L., CYNOBER, T., MARDEN, M. C., WAJCMAN, H. and DOUAY, L. (2005). Ex vivo generation of fully mature human red blood cells from hematopoietic stem cells. Nat.Biotechnol. 1: 69-74.

GIRALDEZ, A. J., CINALLI, R. M., GLASNER, M. E., ENRIGHT, A. J., THOMSON, J. M., BASKERVILLE, S., HAMMOND, S. M., BARTEL, D. P. and SCHIER, A. F. (2005). MicroRNAs regulate brain morphogenesis in zebrafish. Science 5723: 833-838.

GLINKA, A., WU, W., DELIUS, H., MONAGHAN, A. P., BLUMENSTOCK, C. and NIEHRS, C. (1998). Dickkopf- 1 is a member of a new family of secreted proteins and functions in head induction. Nature 6665: 357-362.

GRADY, E. F., SECHI, L. A., GRIFFIN, C. A., SCHAMBELAN, M. and KALINYAK, J. E. (1991). Expression of AT2 receptors in the developing rat fetus. J.Clin. Invest. 3: 921-933

GRAMMATOPOULOS, T. N., AHMADI, F., JONES, S. M., FARISS, M. W., WEYHENMEYER, J. A. and ZAWADA, W. M. (2005). Angiotensin II protects cultured midbrain dopaminergic neurons against rotenone-induced cell death. Brain Res. 1-2: 64-71.

GREGORY, P. A., BERT, A. G., PATERSON, E. L., BARRY, S. C., TSYKIN, A., FARSHID, G., VADAS, M. A., KHEW-GOODALL, Y. and GOODALL, G. J. (2008). The miR-200 family and miR-205 regulate epithelial to mesenchymal transition by targeting ZEB1 and SIP1. Nat.Cell Biol. 5: 593-601.

GREWAL, S. S., BARKER, J. N., DAVIES, S. M. and WAGNER, J. E. (2003). Unrelated donor hematopoietic cell transplantation: marrow or umbilical cord blood? Blood 11: 4233-4244

GRIER, D. G., THOMPSON, A., KWASNIEWSKA, A., MCGONIGLE, G. J., HALLIDAY, H. L. and LAPPIN, T. R. (2005). The pathophysiology of HOX genes and their role in cancer. J.Pathol. 2: 154-171.

HACEIN-BEY-ABINA, S., VON KALLE, C., SCHMIDT, M., MCCORMACK, M. P., WULFFRAAT, N., LEBOULCH, P., LIM, A., OSBORNE, C. S., PAWLIUK, R., MORILLON, E., SORENSEN, R., FORSTER, A., FRASER, P., COHEN, J. I., DE SAINT BASILE, G., ALEXANDER, I., WINTERGERST, U., FREBOURG, T., AURIAS, A., STOPPA-LYONNET, D., ROMANA, S., RADFORD-WEISS, I., GROSS, F., VALENSI, F., DELABESSE, E., MACINTYRE, E., SIGAUX, F., SOULIER, J., LEIVA, L. E., WISSLER, M., PRINZ, C., RABBITTS, T. H., LE DEIST, F., FISCHER, A. and CAVAZZANA-CALVO, M. (2003). LMO2-associated clonal $\mathrm{T}$ cell proliferation in two patients after gene therapy for SCID-X1. Science 5644: 415-419.

HADLAND, B. K., HUPPERT, S. S., KANUNGO, J., XUE, Y., JIANG, R., GRIDLEY, T., CONLON, R. A., CHENG, A. M., KOPAN, R. and LONGMORE, G. D. (2004). A requirement for Notch1 distinguishes 2 phases of definitive hematopoiesis during development. Blood 10: 3097-3105.

HANNA, J., WERNIG, M., MARKOULAKI, S., SUN, C. W., MEISSNER, A.,
CASSADY, J. P., BEARD, C., BRAMBRINK, T., WU, L. C., TOWNES, T. M. and JAENISCH, R. (2007). Treatment of sickle cell anemia mouse model with iPS cells generated from autologous skin. Science 5858: 1920-1923.

HARE, K. J., JENKINSON, E. J. and ANDERSON, G. (1999). In vitro models of T cell development. Semin.Immunol. 1: 3-12.

HAY, D. C., FLETCHER, J., PAYNE, C., TERRACE, J. D., GALLAGHER, R. C., SNOEYS, J., BLACK, J. R., WOJTACHA, D., SAMUEL, K., HANNOUN, Z., PRYDE, A., FILIPPI, C., CURRIE, I. S., FORBES, S. J., ROSS, J. A., NEWSOME P. N. and IREDALE, J. P. (2008). Highly efficient differentiation of hESCs to functional hepatic endoderm requires ActivinA and Wnt3a signaling. Proc. Nat/. Acad. SCi. USA 34: 12301-12306.

HEFFELFINGER, S. C. (2007). The renin angiotensin system in the regulation of angiogenesis. Curr.Pharm.Des. 12: 1215-1229.

HESS, J. L. (2004). MLL: a histone methyltransferase disrupted in leukemia. Trends Mol.Med. 10: 500-507.

HESS, J. L., YU, B. D., LI, B., HANSON, R. and KORSMEYER, S. J. (1997). Defects in yolk sac hematopoiesis in MII-null embryos. Blood5: 1799-1806.

HIROYAMA, T., MIHARADA, K., SUDO, K., DANJO, I., AOKI, N. and NAKAMURA Y. (2008). Establishment of mouse embryonic stem cell-derived erythroid progenitor cell lines able to produce functional red blood cells. PLOS ONE2: e1544.

HORN, J. M. and ASHWORTH, A. (1995). A member of the caudal family of homeobox genes maps to the $\mathrm{X}$-inactivation centre region of the mouse and human X chromosomes. Hum.Mol. Genet. 6: 1041-1047.

HOUBAVIY, H. B., MURRAY, M. F. and SHARP, P. A. (2003). Embryonic stem cellspecific MicroRNAs. Dev.Cell. 2: 351-358.

HUANGFU, D., MAEHR, R., GUO, W., EIJKELENBOOM, A., SNITOW, M., CHEN, A. E. and MELTON, D. A. (2008a). Induction of pluripotent stem cells by defined factors is greatly improved by small-molecule compounds. Nat.Biotechnol. 7 : 795-797.

HUANGFU, D., OSAFUNE, K., MAEHR, R., GUO, W., EIJKELENBOOM, A., CHEN, S., MUHLESTEIN, W. and MELTON, D. A. (2008b). Induction of pluripotent stem cells from primary human fibroblasts with only Oct4 and Sox2. Nat.Biotechnol. 11: 1269-1275.

HUBER, T. L., KOUSKOFF, V., FEHLING, H. J., PALIS, J. and KELLER, G. (2004). Haemangioblast commitment is initiated in the primitive streak of the mouse embryo. Nature 7017: 625-630.

HUBERT, C., SAVARY, K., GASC, J. M. and CORVOL, P. (2006). The hematopoietic system: a new niche for the renin-angiotensin system. Nat.Clin.Pract.Cardiovasc.Med. 2: 80-85.

ISHII, T., FUKUMITSU, K., YASUCHIKA, K., ADACHI, K., KAWASE, E., SUEMORI H., NAKATSUJI, N., IKAI, I. and UEMOTO, S. (2008). Effects of extracellular matrixes and growth factors on the hepatic differentiation of human embryonic stem cells. Am.J.Physiol.Gastrointest.Liver Physiol. 2: G313-21.

ITOH, K., TEZUKA, H., SAKODA, H., KONNO, M., NAGATA, K., UCHIYAMA, T. UCHINO, H. and MORI, K. J. (1989). Reproducible establishment of hemopoietic supportive stromal cell lines from murine bone marrow. Exp.Hematol. 2 145-153.

IVEY, K. N., MUTH, A., ARNOLD, J., KING, F. W., YEH, R. F., FISH, J. E., HSIAO, E. C., SCHWARTZ, R. J., CONKLIN, B. R., BERNSTEIN, H. S. and SRIVASTAVA, D. (2008). MicroRNA regulation of cell lineages in mouse and human embryonic stem cells. Cell.Stem Cell. 3: 219-229.

JAFFREDO, T., NOTTINGHAM, W., LIDDIARD, K., BOLLEROT, K., POUGET, C. and DE BRUIJN, M. (2005). From hemangioblast to hematopoietic stem cell: an endothelial connection? Exp. Hematol. 9: 1029-1040.

JAMES, D., LEVINE, A. J., BESSER, D. and HEMMATI-BRIVANLOU, A. (2005). TGFbeta/activin/nodal signaling is necessary for the maintenance of pluripotency in human embryonic stem cells. Development 6: 1273-1282.

JENKINSON, E. J. and ANDERSON, G. (1994). Fetal thymic organ cultures. Curr. Opin.Immunol. 2: 293-297.

JOH, T., HOSOKAWA, Y., SUZUKI, R., TAKAHASHI, T. and SETO, M. (1999). Establishment of an inducible expression system of chimeric MLL-LTG9 protein and inhibition of Hox a7, Hox b7 and Hox c9 expression by MLL-LTG9 in 32Dcl3 cells. Oncogene 4: 1125-1130.

JOH, T., KAGAMI, Y., YAMAMOTO, K., SEGAWA, T., TAKIZAWA, J., TAKAHASHI T., UEDA, R. and SETO, M. (1996). Identification of MLL and chimeric MLL gene 
products involved in 11q23 translocation and possible mechanisms of leukemogenesis by MLL truncation. Oncogene 9: 1945-1953.

JOHANSSON, B. M. and WILES, M. V. (1995). Evidence for involvement of activin $A$ and bone morphogenetic protein 4 in mammalian mesoderm and hematopoietic development. Mol.Cell.Biol. 1: 141-151.

JOHNSON, J. J., CHEN, W., HUDSON, W., YAO, Q., TAYLOR, M., RABBITTS, T. H. and KERSEY, J. H. (2003). Prenatal and postnatal myeloid cells demonstrate stepwise progression in the pathogenesis of MLL fusion gene leukemia. Blood 8: 3229-3235.

KABRUN, N., BUHRING, H. J., CHOI, K., ULLRICH, A., RISAU, W. and KELLER, G. (1997). Flk-1 expression defines a population of early embryonic hematopoietic precursors. Development 10: 2039-2048.

KAUFMAN, D. S., HANSON, E. T., LEWIS, R. L., AUERBACH, R. and THOMSON, J. A. (2001). Hematopoietic colony-forming cells derived from human embryonic stem cells. Proc. Natl. Acad. Sci. USA 19: 10716-10721.

KAUFMAN, M. H., ROBERTSON, E. J., HANDYSIDE, A. H. and EVANS, M. J. (1983). Establishment of pluripotential cell lines from haploid mouse embryos. J.Embryol.Exp.Morphol.249-261.

KELLER, G., KENNEDY, M., PAPAYANNOPOULOU, T. and WILES, M. V. (1993). Hematopoietic commitment during embryonic stem cell differentiation in culture. Mol.Cell.Biol. 1: 473-486.

KEMP, C., WILLEMS, E., ABDO, S., LAMBIV, L. and LEYNS, L. (2005). Expression of all Wnt genes and their secreted antagonists during mouse blastocyst and postimplantation development. Dev.Dyn. 3: 1064-1075.

KENNEDY, M., D'SOUZA, S. L., LYNCH-KATTMAN, M., SCHWANTZ, S. and KELLER, G. (2007). Development of the hemangioblast defines the onset of hematopoiesis in human ES cell differentiation cultures. Blood7: 2679-2687.

KENNEDY, M., FIRPO, M., CHOI, K., WALL, C., ROBERTSON, S., KABRUN, N. and KELLER, G. (1997). A common precursor for primitive erythropoiesis and definitive haematopoiesis. Nature 6624: 488-493.

KIM, D., KIM, C., MOON, J., CHUNG, Y., CHANG, M., HAN, B., KO, S., YANG, E., CHA, K. Y., LANZA, R. and KIM, K. (2009). Generation of human induced pluripotent stem cells by direct delivery of reprogramming proteins. Cell Stem Ce//4: 472-476.

KIM, J. B., ZAEHRES, H., WU, G., GENTILE, L., KO, K., SEBASTIANO, V., ARAUZO-BRAVO, M. J., RUAU, D., HAN, D. W., ZENKE, M. and SCHOLER, H. R. (2008). Pluripotent stem cells induced from adult neural stem cells by reprogramming with two factors. Nature 7204: 646-650.

KIM, K., LEROU, P., YABUUCHI, A., LENGERKE, C., NG, K., WEST, J., KIRBY, A., DALY, M. J. and DALEY, G. Q. (2007). Histocompatible embryonic stem cells by parthenogenesis. Science 5811 : 482-486.

KIMURA, C., YOSHINAGA, K., TIAN, E., SUZUKI, M., AIZAWA, S. and MATSUO, I. (2000). Visceral endoderm mediates forebrain development by suppressing posteriorizing signals. Dev.Biol. 2: 304-321.

$\mathrm{KOCH}, \mathrm{H}$., JADLOWIEC, J. A. and CAMPBELL, P. G. (2005). Insulin-like growth factor-I induces early osteoblast gene expression in human mesenchymal stem cells. Stem Cells Dev. 6: 621-631.

KONG, C. T., SHAM, M. H., SO, C. W., CHEAH, K. S., CHEN, S. J. and CHAN, L. C. (2006). The MII-Een knockin fusion gene enhances proliferation of myeloid progenitors derived from mouse embryonic stem cells and causes myeloid leukaemia in chimeric mice. Leukemia 10: 1829-1839.

KONO, T., OBATA, Y., YOSHIMZU, T., NAKAHARA, T. and CARROLL, J. (1996). Epigenetic modifications during oocyte growth correlates with extended parthenogenetic development in the mouse. Nat.Genet. 1: 91-94.

KRASSOWSKA, A., GORDON-KEYLOCK, S., SAMUEL, K., GILCHRIST, D., DZIERZAK, E., OOSTENDORP, R., FORRESTER, L. M. and ANSELL, J. D. (2006). Promotion of haematopoietic activity in embryonic stem cells by the aorta-gonad-mesonephros microenvironment. Exp. Cell Res. 18: 3595-3603.

KRIVTSOV, A. V., TWOMEY, D., FENG, Z., STUBBS, M. C., WANG, Y., FABER, J., LEVINE, J. E., WANG, J., HAHN, W. C., GILLILAND, D. G., GOLUB, T. R. and ARMSTRONG, S. A. (2006). Transformation from committed progenitor to leukaemia stem cell initiated by MLL-AF9. Nature 7104: 818-822.

KROSL, J., BESLU, N., MAYOTTE, N., HUMPHRIES, R. K. and SAUVAGEAU, G. (2003). The competitive nature of HOXB4-transduced HSC is limited by PBX1: the generation of ultra-competitive stem cells retaining full differentiation potential. Immunity 4: 561-571.
KRUTZFELDT, J., RAJEWSKY, N., BRAICH, R., RAJEEV, K. G., TUSCHL, T., MANOHARAN, M. and STOFFEL, M. (2005). Silencing of microRNAs in vivo with 'antagomirs'. Nature 7068: 685-689.

KUMANO, K., CHIBA, S., KUNISATO, A., SATA, M., SAITO, T., NAKAGAMIYAMAGUCHI, E., YAMAGUCHI, T., MASUDA, S., SHIMIZU, K., TAKAHASHI, T., OGAWA, S., HAMADA, Y. and HIRAI, H. (2003). Notch1 but not Notch2 is essential for generating hematopoietic stem cells from endothelial cells. Immunity 5: 699-711.

KYBA, M., PERLINGEIRO, R. C. and DALEY, G. Q. (2002). HoxB4 confers definitive lymphoid-myeloid engraftment potential on embryonic stem cell and yolk sac hematopoietic progenitors. Cel/1: 29-37.

KYBA, M., PERLINGEIRO, R. C., HOOVER, R. R., LU, C. W., PIERCE, J. and DALEY, G. Q. (2003). Enhanced hematopoietic differentiation of embryonic stem cells conditionally expressing Stat5. Proc. Natl. Acad. Sci. USA1190411910.

LA MOTTE-MOHS, R. N., AWONG, G. and ZÚÑIGA-PFLÜCKER, J. C. (2007). In vitro models of human $\mathrm{T}$ cell development: dishing out progenitor T cells. Curr. Immunol. Rev. 3: 57-75.

LA MOTTE-MOHS, R. N., HERER, E. and ZUNIGA-PFLUCKER, J. C. (2005). Induction of T-cell development from human cord blood hematopoietic stem cells by Delta-like 1 in vitro. Blood4: 1431-1439.

LACAUD, G., GORE, L., KENNEDY, M., KOUSKOFF, V., KINGSLEY, P., HOGAN C., CARLSSON, L., SPECK, N., PALIS, J. and KELLER, G. (2002). Runx1 is essential for hematopoietic commitment at the hemangioblast stage of development in vitro. Blood2: 458-466.

LAGOS-QUINTANA, M., RAUHUT, R., LENDECKEL, W. and TUSCHL, T. (2001). Identification of novel genes coding for small expressed RNAs. Science 5543: 853-858.

LAKO, M., LINDSAY, S., LINCOLN, J., CAIRNS, P. M., ARMSTRONG, L. and HOLE, N. (2001). Characterisation of Wnt gene expression during the differentiation of murine embryonic stem cells in vitro: role of Wnt3 in enhancing haematopoietic differentiation. Mech.Dev. 1-2: 49-59.

LANCRIN, C., SROCZYNSKA, P., STEPHENSON, C., ALLEN, T., KOUSKOFF, V. and LACAUD, G. (2009). The haemangioblast generates haematopoietic cells through a haemogenic endothelium stage. Nature 7231: 892-895.

LANDGRAF, P., RUSU, M., SHERIDAN, R., SEWER, A., IOVINO, N., ARAVIN, A., PFEFFER, S., RICE, A., KAMPHORST, A. O., LANDTHALER, M., LIN, C., SOCCI, N. D., HERMIDA, L., FULCI, V., CHIARETTI, S., FOA, R., SCHLIWKA J., FUCHS, U., NOVOSEL, A., MULLER, R. U., SCHERMER, B., BISSELS, U., INMAN, J., PHAN, Q., CHIEN, M., WEIR, D. B., CHOKSI, R., DE VITA, G., FREZZETTI, D., TROMPETER, H. I., HORNUNG, V., TENG, G., HARTMANN, G., PALKOVITS, M., DI LAURO, R., WERNET, P., MACINO, G., ROGLER, C. E., NAGLE, J. W., JU, J., PAPAVASILIOU, F. N., BENZING, T., LICHTER, P. TAM, W., BROWNSTEIN, M. J., BOSIO, A., BORKHARDT, A., RUSSO, J. J., SANDER, C., ZAVOLAN, M. and TUSCHL, T. (2007). A mammalian microRNA expression atlas based on small RNA library sequencing. Ce//7: 1401-1414.

LANDRETH, K. S. and DORSHKIND, K. (1988). Pre-B cell generation potentiated by soluble factors from a bone marrow stromal cell line. J./mmunol. 3: 845-852.

LAU, N. C., LIM, L. P., WEINSTEIN, E. G. and BARTEL, D. P. (2001). An abundant class of tiny RNAs with probable regulatory roles in Caenorhabditis elegans. Science 5543: 858-862.

LAWSON, K. A., MENESES, J. J. and PEDERSEN, R. A. (1991). Clonal analysis of epiblast fate during germ layer formation in the mouse embryo. Development 3: 891-911.

LEDRAN, M. H., KRASSOWSKA, A., ARMSTRONG, L., DIMMICK, I., RENSTROM, J., LANG, R., YUNG, S., SANTIBANEZ-COREF, M., DZIERZAK, E., STOJKOVIC, M., OOSTENDORP, R. A., FORRESTER, L. and LAKO, M. (2008). Efficient hematopoietic differentiation of human embryonic stem cells on stromal cells derived from hematopoietic niches. Cell. Stem Cell. 1: 85-98.

LEE, R. C. and AMBROS, V. (2001). An extensive class of small RNAs in Caenorhabditis elegans. Science 5543: 862-864.

LEE, R. C., FEINBAUM, R. L. and AMBROS, V. (1993). The C. elegans heterochronic gene lin-4 encodes small RNAs with antisense complementarity to lin-14. Ce/l 5: 843-854.

LEVENBERG, S., HUANG, N. F., LAVIK, E., ROGERS, A. B., ITSKOVITZ-ELDOR, J. and LANGER, R. (2003). Differentiation of human embryonic stem cells on three-dimensional polymer scaffolds. Proc. Natl. Acad. Sci. USA 22: 12741 . 
12746.

LI, F., LU, S., VIDA, L., THOMSON, J. A. and HONIG, G. R. (2001a). Bone morphogenetic protein 4 induces efficient hematopoietic differentiation of rhesus monkey embryonic stem cells in vitro. Blood2: 335-342.

LI, X., CHEN, Y., SCHEELE, S., ARMAN, E., HAFFNER-KRAUSZ, R., EKBLOM, P. and LONAI, P. (2001b). Fibroblast growth factor signaling and basement membrane assembly are connected during epithelial morphogenesis of the embryoid body. J.Cell Biol. 4: 811-822.

LIEBER, J. G., KELLER, G. M. and WORTHEN, G. S. (2003). The in vitro differentiation of mouse embryonic stem cells into neutrophils. Methods Enzymol.129-142.

LIEBER, J. G., WEBB, S., SURATT, B. T., YOUNG, S. K., JOHNSON, G. L., KELLER, G. M. and WORTHEN, G. S. (2004). The in vitro production and characterization of neutrophils from embryonic stem cells. Blood 3: 852-859.

LIEW, A., BARRY, F. and O'BRIEN, T. (2006). Endothelial progenitor cells: diagnostic and therapeutic considerations. Bioessays 3: 261-270.

LIM, L. P., LAU, N. C., GARRETT-ENGELE, P., GRIMSON, A., SCHELTER, J. M., CASTLE, J., BARTEL, D. P., LINSLEY, P. S. and JOHNSON, J. M. (2005). Microarray analysis shows that some microRNAs downregulate large numbers of target mRNAs. Nature 7027: 769-773.

LIN, G., OUYANG, Q., ZHOU, X., GU, Y., YUAN, D., LI, W., LIU, G., LIU, T. and LU, G. (2007). A highly homozygous and parthenogenetic human embryonic stem cell line derived from a one-pronuclear oocyte following in vitro fertilization procedure. Cell Res. 12: 999-1007.

LIN, S. L., CHANG, D. C., CHANG-LIN, S., LIN, C. H., WU, D. T., CHEN, D. T. and YING, S. Y. (2008). Mir-302 reprograms human skin cancer cells into a pluripotent ES-cell-like state. RNA 10: 2115-2124.

LIU, P., WAKAMIYA, M., SHEA, M. J., ALBRECHT, U., BEHRINGER, R. R. and BRADLEY, A. (1999). Requirement for Wnt3 in vertebrate axis formation. Nat.Genet. 4: 361-365.

LOH, Y. H., AGARWAL, S., PARK, I. H., URBACH, A., HUO, H., HEFFNER, G. C., KIM, K., MILLER, J. D., NG, K. and DALEY, G. Q. (2009). Generation of induced pluripotent stem cells from human blood. Blood22: 5476-5479.

LU, S. J., FENG, Q., PARK, J. S., VIDA, L., LEE, B. S., STRAUSBAUCH, M., WETTSTEIN, P. J., HONIG, G. R. and LANZA, R. (2008). Biologic properties and enucleation of red blood cells from human embryonic stem cells. Blood12: 4475-4484

LU, S. J., LI, F., VIDA, L. and HONIG, G. R. (2004). CD34+CD38- hematopoietic precursors derived from human embryonic stem cells exhibit an embryonic gene expression pattern. Blood 11: 4134-4141.

MA, F., EBIHARA, Y., UMEDA, K., SAKAI, H., HANADA, S., ZHANG, H., ZAIKE, Y., TSUCHIDA, E., NAKAHATA, T., NAKAUCHI, H. and TSUJI, K. (2008a). Generation of functional erythrocytes from human embryonic stem cell-derived definitive hematopoiesis. Proc. Natl. Acad. Sci. USA 35: 13087-13092.

MA, F., EBIHARA, Y., UMEDA, K., SAKAI, H., HANADA, S., ZHANG, H., ZAIKE, Y., TSUCHIDA, E., NAKAHATA, T., NAKAUCHI, H. and TSUJI, K. (2008b). Generation of functional erythrocytes from human embryonic stem cell-derived definitive hematopoiesis. Proc. Natl. Acad. Sci. USA 35: 13087-13092.

MA, Y., RAMEZANI, A., LEWIS, R., HAWLEY, R. G. and THOMSON, J. A. (2003). High-level sustained transgene expression in human embryonic stem cells using lentiviral vectors. Stem Cel/s 1: 111-117.

MAI, Q., YU, Y., LI, T., WANG, L., CHEN, M. J., HUANG, S. Z., ZHOU, C. and ZHOU, Q. (2007). Derivation of human embryonic stem cell lines from parthenogenetic blastocysts. Cell Res. 12: 1008-1019.

MARSON, A., LEVINE, S. S., COLE, M. F., FRAMPTON, G. M., BRAMBRINK, T., JOHNSTONE, S., GUENTHER, M. G., JOHNSTON, W. K., WERNIG, M., NEWMAN, J., CALABRESE, J. M., DENNIS, L. M., VOLKERT, T. L., GUPTA, S., LOVE, J., HANNETT, N., SHARP, P. A., BARTEL, D. P., JAENISCH, R. and YOUNG, R. A. (2008). Connecting microRNA genes to the core transcriptional regulatory circuitry of embryonic stem cells. Cel/3: 521-533.

MARTELLO, G., ZACCHIGNA, L., INUI, M., MONTAGNER, M., ADORNO, M., MAMIDI, A., MORSUT, L., SOLIGO, S., TRAN, U., DUPONT, S., CORDENONSI, M., WESSELY, O. and PICCOLO, S. (2007). MicroRNA control of Nodal signalling. Nature 7159: 183-188.

MARTIN, C. H., WOLL, P. S., NI, Z., ZUNIGA-PFLUCKER, J. C. and KAUFMAN, D. S. (2008). Differences in lymphocyte developmental potential between human embryonic stem cell and umbilical cord blood-derived hematopoietic progenitor cells. Blood 7: 2730-2737.

MARTIN, M. A. and BHATIA, M. (2005). Analysis of the human fetal liver hematopoietic microenvironment. Stem Cel/s Dev. 5: 493-504.

MARTIN, M. E., MILNE, T. A., BLOYER, S., GALOIAN, K., SHEN, W., GIBBS, D., BROCK, H. W., SLANY, R. and HESS, J. L. (2003). Dimerization of MLL fusion proteins immortalizes hematopoietic cells. Cancer.Cell. 3: 197-207.

MATSUOKA, S., TSUJI, K., HISAKAWA, H., XU, M., EBIHARA, Y., ISHII, T., SUGIYAMA, D., MANABE, A., TANAKA, R., IKEDA, Y., ASANO, S. and NAKAHATA, T. (2001). Generation of definitive hematopoietic stem cells from murine early yolk sac and paraaortic splanchnopleures by aorta-gonad-mesonephros region-derived stromal cells. Blood 1: 6-12.

MCCORMACK, M. P. and RABBITTS, T. H. (2004). Activation of the T-cell oncogene LMO2 after gene therapy for $\mathrm{X}$-linked severe combined immunodeficiency. N.Engl.J.Med. 9: 913-922.

MCLEAN, A. B., D'AMOUR, K. A., JONES, K. L., KRISHNAMOORTHY, M., KULIK, M. J., REYNOLDS, D. M., SHEPPARD, A. M., LIU, H., XU, Y., BAETGE, E. E. and DALTON, S. (2007). Activin a efficiently specifies definitive endoderm from human embryonic stem cells only when phosphatidylinositol 3-kinase signaling is suppressed. Stem Cells 1: 29-38.

MEDVINSKY, A. and DZIERZAK, E. (1996). Definitive hematopoiesis is autonomously initiated by the AGM region. Ce//6: 897-906.

MENDES, S. C., ROBIN, C. and DZIERZAK, E. (2005). Mesenchymal progenitor cells localize within hematopoietic sites throughout ontogeny. Development5: 1127-1136.

MENO, C., GRITSMAN, K., OHISHI, S., OHFUJI, Y., HECKSCHER, E., MOCHIDA, K., SHIMONO, A., KONDOH, H., TALBOT, W. S., ROBERTSON, E. J., SCHIER, A. F. and HAMADA, H. (1999). Mouse Lefty2 and zebrafish antivin are feedback inhibitors of nodal signaling during vertebrate gastrulation. Mol.Ce//3: 287-298.

MESNARD, D., GUZMAN-AYALA, M. and CONSTAM, D. B. (2006). Nodal specifies embryonic visceral endoderm and sustains pluripotent cells in the epiblast before overt axial patterning. Development 13: 2497-2505.

MEYER, C., SCHNEIDER, B., JAKOB, S., STREHL, S., ATTARBASCHI, A. SCHNITTGER, S., SCHOCH, C., JANSEN, M. W., VAN DONGEN, J. J., DEN BOER, M. L., PIETERS, R., ENNAS, M. G., ANGELUCCI, E., KOEHL, U., GREIL, J., GRIESINGER, F., ZUR STADT, U., ECKERT, C., SZCZEPANSKI, T., NIGGLI, F. K., SCHAFER, B. W., KEMPSKI, H., BRADY, H. J., ZUNA, J., TRKA, J., NIGRO, L. L., BIONDI, A., DELABESSE, E., MACINTYRE, E., STANULLA, M., SCHRAPPE, M., HAAS, O. A., BURMEISTER, T., DINGERMANN, T., KLINGEBIEL, T. and MARSCHALEK, R. (2006). The MLL recombinome of acute leukemias. Leukemia 5: 777-784.

MIHARADA, K., HIROYAMA, T., SUDO, K., NAGASAWA, T. and NAKAMURA, Y (2006). Efficient enucleation of erythroblasts differentiated in vitrofrom hematopoietic stem and progenitor cells. Nat.Biotechnol. 10: 1255-1256.

MILNE, T. A., DOU, Y., MARTIN, M. E., BROCK, H. W., ROEDER, R. G. and HESS, J. L. (2005a). MLL associates specifically with a subset of transcriptionally active target genes. Proc. Natl. Acad. Sci. USA 41: 14765-14770.

MILNE, T. A., MARTIN, M. E., BROCK, H. W., SLANY, R. K. and HESS, J. L. (2005b). Leukemogenic MLL fusion proteins bind across a broad region of the Hox a9 locus, promoting transcription and multiple histone modifications. Cancer Res. 24: 11367-11374.

MIYAGI, T., TAKENO, M., NAGAFUCHI, H., TAKAHASHI, M. and SUZUKI, N (2002). Flk1+ cells derived from mouse embryonic stem cells reconstitute hematopoiesis in vivo in SCID mice. Exp. Hematol. 12: 1444-1453.

MORALI, O. G., JOUNEAU, A., MCLAUGHLIN, K. J., THIERY, J. P. and LARUE, L. (2000). IGF-II promotes mesoderm formation. Dev.Biol. 1: 133-145.

MUGURUMA, Y., YAHATA, T., MIYATAKE, H., SATO, T., UNO, T., ITOH, J., KATO, S., ITO, M., HOTTA, T. and ANDO, K. (2006). Reconstitution of the functional human hematopoietic microenvironment derived from human mesenchymal stem cells in the murine bone marrow compartment. Blood5: 1878 1887.

MURDOCH, B., GALLACHER, L., CHADWICK, K., FELLOWS, F. and BHATIA, M. (2002). Human embryonic-derived hematopoietic repopulating cells require distinct factors to sustain in vivo repopulating function. Exp.Hematol. 6: 598 605.

MURRAY, P. D. F. (1932). The development in vitro of the early chick embryo. Proc 
Roy Soc London 11: 497-521.

NAKAGAWA, M., ICHIKAWA, M., KUMANO, K., GOYAMA, S., KAWAZU, M., ASAI, T., OGAWA, S., KUROKAWA, M. and CHIBA, S. (2006). AML1/Runx1 rescues Notch1-null mutation-induced deficiency of para-aortic splanchnopleural hematopoiesis. Blood 10: 3329-3334.

NAKAGAWA, M., KOYANAGI, M., TANABE, K., TAKAHASHI, K., ICHISAKA, T., AOI, T., OKITA, K., MOCHIDUKI, Y., TAKIZAWA, N. and YAMANAKA, S. (2008). Generation of induced pluripotent stem cells without Myc from mouse and human fibroblasts. Nat.Biotechnol. 1: 101-106.

NAKANO, T., KODAMA, H. and HONJO, T. (1996). In vitrodevelopment of primitive and definitive erythrocytes from different precursors. Science 5262: 722-724.

NAKAYAMA, N., LEE, J. and CHIU, L. (2000). Vascular endothelial growth factor synergistically enhances bone morphogenetic protein-4-dependent lymphohematopoietic cell generation from embryonic stem cells in vitro. Blood 7: 2275-2283.

NARAYAN, A. D., CHASE, J. L., LEWIS, R. L., TIAN, X., KAUFMAN, D. S. THOMSON, J. A. and ZANJANI, E. D. (2006). Human embryonic stem cellderived hematopoietic cells are capable of engrafting primary as well as secondary fetal sheep recipients. Blood5: 2180-2183.

NEILDEZ-NGUYEN, T. M., WAJCMAN, H., MARDEN, M. C., BENSIDHOUM, M., MONCOLLIN, V., GIARRATANA, M. C., KOBARI, L., THIERRY, D. and DOUAY, L. (2002). Human erythroid cells produced ex vivo at large scale differentiate into red blood cells in vivo. Nat.Biotechnol. 5: 467-472.

NEILSON, J. R., ZHENG, G. X., BURGE, C. B. and SHARP, P. A. (2007). Dynamic regulation of miRNA expression in ordered stages of cellular development. Genes Dev. 5: 578-589.

NIKLASON, L. E. (1999). Techview: medical technology. Replacement arteries made to order. Science 5444: 1493-1494.

NISWANDER, L. and MARTIN, G. R. (1992). Fgf-4 expression during gastrulation, myogenesis, limb and tooth development in the mouse. Development 3: 755768.

NOORT, W. A., KRUISSELBRINK, A. B., IN'T ANKER, P. S., KRUGER, M., VAN BEZOOIJEN, R. L., DE PAUS, R. A., HEEMSKERK, M. H., LOWIK, C. W. FALKENBURG, J. H., WILLEMZE, R. and FIBBE, W. E. (2002). Mesenchymal stem cells promote engraftment of human umbilical cord blood-derived CD34(+) cells in NOD/SCID mice. Exp. Hematol. 8: 870-878.

NORTH, T., GU, T. L., STACY, T., WANG, Q., HOWARD, L., BINDER, M., MARINPADILLA, M. and SPECK, N. A. (1999). Cbfa2 is required for the formation of intra-aortic hematopoietic clusters. Development 11: 2563-2575.

NORTH, T. E., DE BRUIJN, M. F., STACY, T., TALEBIAN, L., LIND, E., ROBIN, C., BINDER, M., DZIERZAK, E. and SPECK, N. A. (2002). Runx1 expression marks long-term repopulating hematopoietic stem cells in the midgestation mouse embryo. Immunity 5: 661-672.

OBERLIN, E., TAVIAN, M., BLAZSEK, I. and PEAULT, B. (2002). Blood-forming potential of vascular endothelium in the human embryo. Development 17: 41474157.

OKABAYASHI, K. and ASASHIMA, M. (2003). Tissue generation from amphibian animal caps. Curr.Opin.Genet.Dev. 5: 502-507.

OKITA, K., ICHISAKA, T. and YAMANAKA, S. (2007). Generation of germlinecompetent induced pluripotent stem cells. Nature 7151: 313-317.

OKITA, K., NAKAGAWA, M., HYENJONG, H., ICHISAKA, T. and YAMANAKA, S. (2008). Generation of mouse induced pluripotent stem cells without viral vectors. Science 5903: 949-953.

OKUDA, T., VAN DEURSEN, J., HIEBERT, S. W., GROSVELD, G. and DOWNING, J. R. (1996). AML1, the target of multiple chromosomal translocations in human leukemia, is essential for normal fetal liver hematopoiesis. Ce//2: 321-330.

OLIVIER, E. N., QIU, C., VELHO, M., HIRSCH, R. E. and BOUHASSIRA, E. E. (2006). Large-scale production of embryonic red blood cells from human embryonic stem cells. Exp.Hematol. 12: 1635-1642.

OLSEN, A. L., STACHURA, D. L. and WEISS, M. J. (2006). Designer blood: creating hematopoietic lineages from embryonic stem cells. Blood 4: 12651275.

OWENS, B. M. and HAWLEY, R. G. (2002). HOX and non-HOX homeobox genes in leukemic hematopoiesis. Stem Cells 5: 364-379.

PARK, C., AFRIKANOVA, I., CHUNG, Y. S., ZHANG, W. J., ARENTSON, E., FONG $\mathrm{GH}, \mathrm{G}$., ROSENDAHL, A. and CHOI, K. (2004). A hierarchical order of factors in the generation of FLK1- and SCL-expressing hematopoietic and endothelial progenitors from embryonic stem cells. Development 11: 2749-2762.

PARK, I. H., ARORA, N., HUO, H., MAHERALI, N., AHFELDT, T., SHIMAMURA A., LENSCH, M. W., COWAN, C., HOCHEDLINGER, K. and DALEY, G. Q. (2008a). Disease-specific induced pluripotent stem cells. Ce//5: 877-886.

PARK, I. H., ZHAO, R., WEST, J. A., YABUUCHI, A., HUO, H., INCE, T. A., LEROU, P. H., LENSCH, M. W. and DALEY, G. Q. (2008b). Reprogramming of human somatic cells to pluripotency with defined factors. Nature 7175: 141-146.

PARK, T. S., ZAMBIDIS, E. T., LUCITTI, J. L., LOGAR, A., KELLER, B. B. and PEAULT, B. (2009). Human embryonic stem cell-derived hematoendothelial progenitors engraft chicken embryos. Exp. Hematol. 1: 31-41.

PAUL, M., POYAN MEHR, A. and KREUTZ, R. (2006). Physiology of local reninangiotensin systems. Physiol.Rev. 3: 747-803.

PEARCE, J. J. and EVANS, M. J. (1999). Mml, a mouse Mix-like gene expressed in the primitive streak. Mech.Dev. 1-2: 189-192.

PEREA-GOMEZ, A., SHAWLOT, W., SASAKI, H., BEHRINGER, R. R. and ANG S. (1999). HNF3beta and Lim1 interact in the visceral endoderm to regulate primitive streak formation and anterior-posterior polarity in the mouse embryo. Development 20: 4499-4511.

PEREA-GOMEZ, A., VELLA, F. D., SHAWLOT, W., OULAD-ABDELGHANI, M. CHAZAUD, C., MENO, C., PFISTER, V., CHEN, L., ROBERTSON, E., HAMADA, H., BEHRINGER, R. R. and ANG, S. L. (2002). Nodal antagonists in the anterior visceral endoderm prevent the formation of multiple primitive streaks. Dev. Cell. 5: 745-756.

PERLINGEIRO, R. C., KYBA, M., BODIE, S. and DALEY, G. Q. (2003). A role for thrombopoietin in hemangioblast development. Stem Cel/s 3: 272-280.

PERLINGEIRO, R. C., KYBA, M. and DALEY, G. Q. (2001). Clonal analysis of differentiating embryonic stem cells reveals a hematopoietic progenitor with primitive erythroid and adult lymphoid-myeloid potential. Development 22 4597-4604.

PLUM, J., DE SMEDT, M., VERHASSELT, B., KERRE, T., VANHECKE, D., VANDEKERCKHOVE, B. and LECLERCQ, G. (2000). Human T lymphopoiesis. In vitro and in vivo study models. Ann.N. Y.Acad.Sci.724-731.

POIREL, H., RACK, K., DELABESSE, E., RADFORD-WEISS, I., TROUSSARD, X., DEBERT, C., LEBOEUF, D., BASTARD, C., PICARD, F., VEIL-BUZYN, A., FLANDRIN, G., BERNARD, O. and MACINTYRE, E. (1996). Incidence and characterization of MLL gene (11q23) rearrangements in acute myeloid leukemia M1 and M5. Blood6: 2496-2505

POTOCNIK, A. J., KOHLER, H. and EICHMANN, K. (1997). Hemato-lymphoid in vivo reconstitution potential of subpopulations derived from in vitro differentiated embryonic stem cells. Proc. Natl. Acad. Sci. USA 19: 10295-10300.

POZNANSKY, M. C., EVANS, R. H., FOXALL, R. B., OLSZAK, I. T., PIASCIK, A H., HARTMAN, K. E., BRANDER, C., MEYER, T. H., PYKETT, M. J., CHABNER, K. T., KALAMS, S. A., ROSENZWEIG, M. and SCADDEN, D. T. (2000). Efficient generation of human $T$ cells from a tissue-engineered thymic organoid. Nat.Biotechnol. 7: 729-734.

PUI, C. H., GAYNON, P. S., BOYETT, J. M., CHESSELLS, J. M., BARUCHEL, A., KAMPS, W., SILVERMAN, L. B., BIONDI, A., HARMS, D. O., VILMER, E., SCHRAPPE, M. and CAMITTA, B. (2002). Outcome of treatment in childhood acute lymphoblastic leukaemia with rearrangements of the 11 q23 chromosomal region. Lancet 9321: 1909-1915.

QIU, C., OLIVIER, E. N., VELHO, M. and BOUHASSIRA, E. E. (2008). Globin switches in yolk sac-like primitive and fetal-like definitive red blood cells produced from human embryonic stem cells. Blood 4: 2400-2408.

RAMKISSOON, S. H., MAINWARING, L. A., OGASAWARA, Y., KEYVANFAR, K. MCCOY, J. P.,JR, SLOAND, E. M., KAJIGAYA, S. and YOUNG, N. S. (2006). Hematopoietic-specific microRNA expression in human cells. Leuk. Res. 5: 643 647.

RAWAT, V. P., CUSAN, M., DESHPANDE, A., HIDDEMANN, W., QUINTANILLAMARTINEZ, L., HUMPHRIES, R. K., BOHLANDER, S. K., FEURING-BUSKE, M. and BUSKE, C. (2004). Ectopic expression of the homeobox gene Cdx2 is the transforming event in a mouse model of $\mathrm{t}(12 ; 13)(\mathrm{p} 13 ; \mathrm{q} 12)$ acute myeloid leukemia. Proc. Natl. Acad. Sci. USA 3: 817-822.

REECE-HOYES, J. S., KEENAN, I. D., POWNALL, M. E. and ISAACS, H. V. (2005) A consensus Oct1 binding site is required for the activity of the Xenopus $\mathrm{Cdx} 4$ promoter. Dev.Biol. 2: 509-523. 
REVAZOVA, E. S., TUROVETS, N. A., KOCHETKOVA, O. D., AGAPOVA, L. S., SEBASTIAN, J. L., PRYZHKOVA, M. V., SMOLNIKOVA, V. I., KUZMICHEV, L. $\mathrm{N}$. and JANUS, J. D. (2008). HLA homozygous stem cell lines derived from human parthenogenetic blastocysts. Cloning Stem Cel/s 1: 11-24.

REVAZOVA, E. S., TUROVETS, N. A., KOCHETKOVA, O. D., KINDAROVA, L. B., KUZMICHEV, L. N., JANUS, J. D. and PRYZHKOVA, M. V. (2007). Patientspecific stem cell lines derived from human parthenogenetic blastocysts. Cloning Stem Cells 3: 432-449.

REYA, T., DUNCAN, A. W., AILLES, L., DOMEN, J., SCHERER, D. C., WILLERT, K., HINTZ, L., NUSSE, R. and WEISSMAN, I. L. (2003). A role for Wnt signalling in self-renewal of haematopoietic stem cells. Nature 6938: 409-414.

ROBB, L., LYONS, I., LI, R., HARTLEY, L., KONTGEN, F., HARVEY, R. P., METCALF, D. and BEGLEY, C. G. (1995). Absence of yolk sac hematopoiesis from mice with a targeted disruption of the scl gene. Proc. Natl. Acad. Sci. USA 15: 7075-7079.

ROBERT-MORENO, A., ESPINOSA, L., DE LA POMPA, J. L. and BIGAS, A. (2005). RBPjkappa-dependent Notch function regulates Gata2 and is essential for the formation of intra-embryonic hematopoietic cells. Development5: 11171126 .

ROBERTSON, S. M., KENNEDY, M., SHANNON, J. M. and KELLER, G. (2000). A transitional stage in the commitment of mesoderm to hematopoiesis requiring the transcription factor SCL/tal-1. Development 11: 2447-2459.

ROSAMOND, W., FLEGAL, K., FURIE, K., GO, A., GREENLUND, K., HAASE, N., HAILPERN, S. M., HO, M., HOWARD, V., KISSELA, B., KITTNER, S., LLOYDJONES, D., MCDERMOTT, M., MEIGS, J., MOY, C., NICHOL, G., O'DONNELL, C., ROGER, V., SORLIE, P., STEINBERGER, J., THOM, T., WILSON, M., HONG, Y. and AMERICAN HEART ASSOCIATION STATISTICS COMMITTEE AND STROKE STATISTICS SUBCOMMITTEE. (2008). Heart disease and stroke statistics - 2008 update: a report from the American Heart Association Statistics Committee and Stroke Statistics Subcommittee. Circulation 4: e25146.

ROZOVSKAIA, T., RAVID-AMIR, O., TILLIB, S., GETZ, G., FEINSTEIN, E., AGRAWAL, H., NAGLER, A., RAPPAPORT, E. F., ISSAEVA, I., MATSUO, Y., KEES, U. R., LAPIDOT, T., LO COCO, F., FOA, R., MAZO, A., NAKAMURA, T., CROCE, C. M., CIMINO, G., DOMANY, E. and CANAANI, E. (2003). Expression profiles of acute lymphoblastic and myeloblastic leukemias with ALL-1 rearrangements. Proc. Natl. Acad. Sci. USA 13: 7853-7858.

RUVKUN, G. (2001). Molecular biology. Glimpses of a tiny RNA world. Science 5543: 797-799.

SABIN, F. R. (1920). Studies on the origin of blood vessels and of red blood corpuscles as seen in the living blastoderm of chicks during the second day of incubation. Contrib. Embryol, Carnegie Institute Washington 9: 214.

SAEKI, K., SAEKI, K., NAKAHARA, M., MATSUYAMA, S., NAKAMURA, N., YOGIASHI, Y., YONEDA, A., KOYANAGI, M., KONDO, Y. and YUO, A. (2008). A Feeder-Free and Efficient Production of Functional Neutrophils from Human Embryonic Stem Cells. Stem Cells

SAITO, Y., KAMETANI, Y., HOZUMI, K., MOCHIDA, N., ANDO, K., ITO, M., NOMURA, T., TOKUDA, Y., MAKUUCHI, H., TAJIMA, T. and HABU, S. (2002). The in vivo development of human T cells from CD34(+) cells in the murine thymic environment. Int.Immunol. 10: 1113-1124.

SAKURAI, H., ERA, T., JAKT, L. M., OKADA, M., NAKAI, S., NISHIKAWA, S. and NISHIKAWA, S. (2006). In vitro modeling of paraxial and lateral mesoderm differentiation reveals early reversibility. Stem Cel/s 3: 575-586.

SAMMONS, J., AHMED, N., EL-SHEEMY, M. and HASSAN, H. T. (2004). The role of BMP-6, IL-6, and BMP-4 in mesenchymal stem cell-dependent bone development: effects on osteoblastic differentiation induced by parathyroid hormone and vitamin D(3). Stem Cel/s Dev. 3: 273-280.

SAMOKHVALOV, I. M., SAMOKHVALOVA, N. I. and NISHIKAWA, S. (2007). Cell tracing shows the contribution of the yolk sac to adult haematopoiesis. Nature 7139: 1056-1061.

SAVARY, K., MICHAUD, A., FAVIER, J., LARGER, E., CORVOL, P. and GASC, J. $M$. (2005). Role of the renin-angiotensin system in primitive erythropoiesis in the chick embryo. Blood 1: 103-110.

SCHMITT, T. M., DE POOTER, R. F., GRONSKI, M. A., CHO, S. K., OHASHI, P. S. and ZUNIGA-PFLUCKER, J. C. (2004). Induction of T cell development and establishment of $\mathrm{T}$ cell competence from embryonic stem cells differentiated in vitro. Nat.Immunol. 4: 410-417.
SCHMITT, T. M. and ZUNIGA-PFLUCKER, J. C. (2002). Induction of T cell development from hematopoietic progenitor cells by delta-like-1 in vitro. Immunity 6: 749-756.

SCHULDINER, M., YANUKA, O., ITSKOVITZ-ELDOR, J., MELTON, D. A. and BENVENISTY, N. (2000). Effects of eight growth factors on the differentiation of cells derived from human embryonic stem cells. Proc. Natl. Acad. Sci. USA 21: 11307-11312.

SCHUTZ, S., LE MOULLEC, J. M., CORVOL, P. and GASC, J. M. (1996). Early expression of all the components of the renin-angiotensin-system in human development. Am.J.Pathol. 6: 2067-2079.

SHIMIZU, T., BAE, Y. K. and HIBI, M. (2006). Cdx-Hox code controls competence for responding to Fgfs and retinoic acid in zebrafish neural tissue. Development 23: 4709-4719.

SHIVDASANI, R. A., MAYER, E. L. and ORKIN, S. H. (1995). Absence of blood formation in mice lacking the T-cell leukaemia oncoprotein tal-1/SCL. Nature 6513: 432-434.

SMITH, J. R., VALLIER, L., LUPO, G., ALEXANDER, M., HARRIS, W. A. and PEDERSEN, R. A. (2008). Inhibition of Activin/Nodal signaling promotes specification of human embryonic stem cells into neuroectoderm. Dev.Biol. 1: 107117.

SOLDNER, F., HOCKEMEYER, D., BEARD, C., GAO, Q., BELL, G. W., COOK, E. G., HARGUS, G., BLAK, A., COOPER, O., MITALIPOVA, M., ISACSON, O. and JAENISCH, R. (2009). Parkinson's disease patient-derived induced pluripotent stem cells free of viral reprogramming factors. Cel/5: 964-977.

SOMERVAILLE, T. C. and CLEARY, M. L. (2006). Identification and characterization of leukemia stem cells in murine MLL-AF9 acute myeloid leukemia. Cancer. Cell. 4: 257-268.

STADTFELD, M., NAGAYA, M., UTIKAL, J., WEIR, G. and HOCHEDLINGER, K. (2008). Induced pluripotent stem cells generated without viral integration. Science 5903: 945-949.

SUH, M. R., LEE, Y., KIM, J. Y., KIM, S. K., MOON, S. H., LEE, J. Y., CHA, K. Y., CHUNG, H. M., YOON, H. S., MOON, S. Y., KIM, V. N. and KIM, K. S. (2004) Human embryonic stem cells express a unique set of microRNAs. Dev.Biol. 2: 488-498.

SUN, X., MEYERS, E. N., LEWANDOSKI, M. and MARTIN, G. R. (1999). Targeted disruption of Fgf8 causes failure of cell migration in the gastrulating mouse embryo. Genes Dev. 14: 1834-1846.

SUZUKI, N., OHNEDA, O., MINEGISHI, N., NISHIKAWA, M., OHTA, T., TAKAHASHI, S., ENGEL, J. D. and YAMAMOTO, M. (2006). Combinatorial Gata2 and Sca1 expression defines hematopoietic stem cells in the bone marrow niche. Proc. Natl. Acad. Sci. USA 7: 2202-2207.

TAICHMAN, R. S. (2005). Blood and bone: two tissues whose fates are intertwined to create the hematopoietic stem-cell niche. Blood7: 2631-2639.

TAKAHASHI, K., OKITA, K., NAKAGAWA, M. and YAMANAKA, S. (2007a). Induction of pluripotent stem cells from fibroblast cultures. Nat.Protoc. 12: 3081 3089.

TAKAHASHI, K., TANABE, K., OHNUKI, M., NARITA, M., ICHISAKA, T., TOMODA, $\mathrm{K}$. and YAMANAKA, S. (2007b). Induction of pluripotent stem cells from adult human fibroblasts by defined factors. Cel/5: 861-872.

TAKAHASHI, K. and YAMANAKA, S. (2006). Induction of pluripotent stem cells from mouse embryonic and adult fibroblast cultures by defined factors. Ce//4: 663-676.

TAKAKURA, N., YOSHIDA, H., OGURA, Y., KATAOKA, H., NISHIKAWA, S. and NISHIKAWA, S. (1997). PDGFR alpha expression during mouse embryogenesis: immunolocalization analyzed by whole-mount immunohistostaining using the monoclonal anti-mouse PDGFR alpha antibody APA5. J.Histochem. Cytochem. 6: 883-893.

TAM, P. P. and BEDDINGTON, R. S. (1987). The formation of mesodermal tissues in the mouse embryo during gastrulation and early organogenesis. Development 1: 109-126.

TAVIAN, M., COULOMBEL, L., LUTON, D., CLEMENTE, H. S., DIETERLENLIEVRE, F. and PEAULT, B. (1996). Aorta-associated CD34+ hematopoietic cells in the early human embryo. Blood 1: 67-72.

TAVIAN, M., HALLAIS, M. F. and PEAULT, B. (1999a). Emergence of intraembryonic hematopoietic precursors in the pre-liver human embryo. Development4: 793803. 
TAVIAN, M., HALLAIS, M. F. and PEAULT, B. (1999b). Emergence of intraembryonic hematopoietic precursors in the pre-liver human embryo. Development 4: 793803.

TAVIAN, M., ROBIN, C., COULOMBEL, L. and PEAULT, B. (2001). The human embryo, but not its yolk sac, generates lympho-myeloid stem cells: mapping multipotent hematopoietic cell fate in intraembryonic mesoderm. Immunity 3: 487-495.

TAYLOR, C. J., BOLTON, E. M., POCOCK, S., SHARPLES, L. D., PEDERSEN, R. A. and BRADLEY, J. A. (2005). Banking on human embryonic stem cells: estimating the number of donor cell lines needed for HLA matching. Lancet 9502: 2019-2025.

THAI, T. H., CALADO, D. P., CASOlA, S., ANSEL, K. M., XIAO, C., XUE, Y., MURPHY, A., FRENDEWEY, D., VALENZUELA, D., KUTOK, J. L., SCHMIDTSUPPRIAN, M., RAJEWSKY, N., YANCOPOULOS, G., RAO, A. and RAJEWSKY, K. (2007). Regulation of the germinal center response by microRNA155. Science 5824: 604-608.

THOMSON, J. A., ITSKOVITZ-ELDOR, J., SHAPIRO, S. S., WAKNITZ, M. A., SWIERGIEL, J. J., MARSHALL, V. S. and JONES, J. M. (1998). Embryonic stem cell lines derived from human blastocysts. Science 282: 1145-1147.

TIAN, X., WOLL, P. S., MORRIS, J. K., LINEHAN, J. L. and KAUFMAN, D. S. (2006). Hematopoietic engraftment of human embryonic stem cell-derived cells is regulated by recipient innate immunity. Stem Cel/s 5: 1370-1380.

TKACHUK, D. C., KOHLER, S. and CLEARY, M. L. (1992). Involvement of a homolog of Drosophila trithorax by 11 q23 chromosomal translocations in acute leukemias. Cel/4: 691-700.

UENO, H. and WEISSMAN, I. L. (2007). Stem cells: blood lines from embryo to adult. Nature 7139: 996-997.

URBACH, A., SCHULDINER, M. and BENVENISTY, N. (2004). Modeling for LeschNyhan disease by gene targeting in human embryonic stem cells. Stem Cells 4 : 635-641.

VALLIER, L., ALEXANDER, M. and PEDERSEN, R. A. (2005). Activin/Nodal and FGF pathways cooperate to maintain pluripotency of human embryonic stem cells. J.Cell. Sci. Pt 19: 4495-4509.

VALLIER, L., RUGG-GUNN, P. J., BOUHON, I. A., ANDERSSON, F. K., SADLER, A. J. and PEDERSEN, R. A. (2004). Enhancing and diminishing gene function in human embryonic stem cells. Stem Cells 1: 2-11.

VARLET, I., COLLIGNON, J. and ROBERTSON, E. J. (1997). Nodal Expression in the Primitive Endoderm is Required for Specification of the Anterior Axis during Mouse Gastrulation. Development 5: 1033-1044.

VERVOORT, V. S., BEACHEM, M. A., EDWARDS, P. S., LADD, S., MILLER, K. E., DE MOLLERAT, X., CLARKSON, K., DUPONT, B., SCHWARTZ, C. E., STEVENSON, R. E., BOYD, E. and SRIVASTAVA, A. K. (2002). AGTR2 mutations in X-linked mental retardation. Science 5577: 2401-2403.

VINCENT, S. D., DUNN, N. R., HAYASHI, S., NORRIS, D. P. and ROBERTSON, E. J. (2003). Cell fate decisions within the mouse organizer are governed by graded Nodal signals. Genes Dev. 13: 1646-1662.

VITTET, D., PRANDINI, M. H., BERTHIER, R., SCHWEITZER, A., MARTINSISTERON, H., UZAN, G. and DEJANA, E. (1996). Embryonic stem cells differentiate in vitro to endothelial cells through successive maturation steps. Blood 9: 3424-3431.

VODYANIK, M. A., BORK, J. A., THOMSON, J. A. and SLUKVIN, I. I. (2005). Human embryonic stem cell-derived CD34+ cells: efficient production in the coculture with OP9 stromal cells and analysis of lymphohematopoietic potential. Blood2: 617-626.

VODYANIK, M. A., THOMSON, J. A. and SLUKVIN, I. I. (2006). Leukosialin (CD43) defines hematopoietic progenitors in human embryonic stem cell differentiation cultures. Blood6: 2095-2105.

VOORHOEVE, P. M., LE SAGE, C., SCHRIER, M., GILLIS, A. J., STOOP, H., NAGEL, R., LIU, Y. P., VAN DUIJSE, J., DROST, J., GRIEKSPOOR, A., ZLOTORYNSKI, E., YABUTA, N., DE VITA, G., NOJIMA, H., LOOIJENGA, L. $H$. and AGAMI, R. (2006). A genetic screen implicates miRNA-372 and miRNA373 as oncogenes in testicular germ cell tumors. Ce//6: 1169-1181.

VRANA, K. E., HIPP, J. D., GOSS, A. M., MCCOOL, B. A., RIDDLE, D. R., WALKER, S. J., WETTSTEIN, P. J., STUDER, L. P., TABAR, V., CUNNIFF, K., CHAPMAN, K., VILNER, L., WEST, M. D., GRANT, K. A. and CIBELLI, J. B. (2003). Nonhuman primate parthenogenetic stem cells. Proc. Natl. Acad. Sci.
USA11911-11916

WANG, L., LI, L., SHOJAEI, F., LEVAC, K., CERDAN, C., MENENDEZ, P., MARTIN, T., ROULEAU, A. and BHATIA, M. (2004). Endothelial and hematopoietic cell fate of human embryonic stem cells originates from primitive endothelium with hemangioblastic properties. Immunity 1: 31-41.

WANG, L., MENENDEZ, P., SHOJAEI, F., LI, L., MAZURIER, F., DICK, J. E., CERDAN, C., LEVAC, K. and BHATIA, M. (2005a). Generation of hematopoietic repopulating cells from human embryonic stem cells independent of ectopic HOXB4 expression. J.Exp.Med. 10: 1603-1614.

WANG, L., MENENDEZ, P., SHOJAEI, F., LI, L., MAZURIER, F., DICK, J. E., CERDAN, C., LEVAC, K. and BHATIA, M. (2005b). Generation of hematopoietic repopulating cells from human embryonic stem cells independent of ectopic HOXB4 expression. J.Exp.Med. 10: 1603-1614.

WANG, Q., STACY, T., BINDER, M., MARIN-PADILLA, M., SHARPE, A. H. and SPECK, N. A. (1996). Disruption of the Cbfa2 gene causes necrosis and hemorrhaging in the central nervous system and blocks definitive hematopoiesis. Proc. Natl. Acad. Sci. USA 8: 3444-3449.

WANG, Y., MEDVID, R., MELTON, C., JAENISCH, R. and BLELLOCH, R. (2007). DGCR8 is essential for microRNA biogenesis and silencing of embryonic stem cell self-renewal. Nat.Genet. 3: 380-385.

WANG, Y., YATES, F., NAVEIRAS, O., ERNST, P. and DALEY, G. Q. (2005). Embryonic stem cell-derived hematopoietic stem cells. Proc. Natl. Acad. Sci. USA 52: 19081-19086.

WEISSMAN, I., PAPAIOANNOU, V. and GARDNER, R. (1978). Differentiation of Normal and Neoplastic Hematopoietic Cells Cold Spring Harbor Conferences on Cell Proliferation 5: 33-47.

WILES, M. V. and KELLER, G. (1991). Multiple hematopoietic lineages develop from embryonic stem (ES) cells in culture. Development 2: 259-267.

WILKINSON, D. G., BHATT, S. and HERRMANN, B. G. (1990). Expression pattern of the mouse T gene and its role in mesoderm formation. Nature6259: 657-659.

WILLERT, K., BROWN, J. D., DANENBERG, E., DUNCAN, A. W., WEISSMAN, I. L., REYA, T., YATES, J. R.,3RD and NUSSE, R. (2003). Wnt proteins are lipidmodified and can act as stem cell growth factors. Nature 6938: 448-452.

WILSON, A. and TRUMPP, A. (2006). Bone-marrow haematopoietic-stem-cell niches. Nat.Rev.Immunol. 2: 93-106.

WINNIER, G., BLESSING, M., LABOSKY, P. A. and HOGAN, B. L. (1995). Bone morphogenetic protein-4 is required for mesoderm formation and patterning in the mouse. Genes Dev. 17: 2105-2116.

WOLTJEN, K., MICHAEL, I. P., MOHSENI, P., DESAI, R., MILEIKOVSKY, M., HAMALAINEN, R., COWLING, R., WANG, W., LIU, P., GERTSENSTEIN, M. KAJI, K., SUNG, H. K. and NAGY, A. (2009). piggyBac transposition reprograms fibroblasts to induced pluripotent stem cells. Nature 7239: 766-770.

WU, Z., ZHANG, W., CHEN, G., CHENG, L., LIAO, J., JIA, N., GAO, Y., DAI, H., YUAN, J., CHENG, L. and XIAO, L. (2008). Combinatorial signals of activin/ nodal and bone morphogenic protein regulate the early lineage segregation of human embryonic stem cells. J.Biol.Chem. 36: 24991-25002.

XIAO, C., CALADO, D. P., GALLER, G., THAI, T. H., PATTERSON, H. C., WANG, J., RAJEWSKY, N., BENDER, T. P. and RAJEWSKY, K. (2007). MiR-150 controls $\mathrm{B}$ cell differentiation by targeting the transcription factor C-Myb. Ce//1: 146-159.

XIAO, L., YUAN, X. and SHARKIS, S. J. (2006). Activin A maintains self-renewal and regulates fibroblast growth factor, Wnt, and bone morphogenic protein pathways in human embryonic stem cells. Stem Cells 6: 1476-1486.

YAMAMOTO, M., SAIJOH, Y., PEREA-GOMEZ, A., SHAWLOT, W., BEHRINGER, R. R., ANG, S. L., HAMADA, H. and MENO, C. (2004). Nodal antagonists regulate formation of the anteroposterior axis of the mouse embryo. Nature 6981: 387-392.

YANG, L., SOONPAA, M. H., ADLER, E. D., ROEPKE, T. K., KATTMAN, S. J., KENNEDY, M., HENCKAERTS, E., BONHAM, K., ABBOTT, G. W., LINDEN, R. M., FIELD, L. J. and KELLER, G. M. (2008). Human cardiovascular progenitor cells develop from a KDR+ embryonic-stem-cell-derived population. Nature 7194: 524-528.

YEKTA, S., SHIH, I. H. and BARTEL, D. P. (2004). MicroRNA-directed cleavage of HOXB8 mRNA. Science 5670: 594-596.

YU, B. D., HANSON, R. D., HESS, J. L., HORNING, S. E. and KORSMEYER, S. J. (1998). MLL, a mammalian trithorax-group gene, functions as a transcriptional 
maintenance factor in morphogenesis. Proc. Natl. Acad. Sci. USA 18: $10632-$ 10636.

YU, B. D., HESS, J. L., HORNING, S. E., BROWN, G. A. and KORSMEYER, S. J. (1995). Altered Hox expression and segmental identity in Mll-mutant mice. Nature 6556: 505-508.

YU, J., HU, K., SMUGA-OTTO, K., TIAN, S., STEWART, R., SLUKVIN, I. I. and THOMSON, J. A. (2009). Human Induced Pluripotent Stem Cells Free of Vector and Transgene Sequences. Science 5928: 797-801.

YU, J., VODYANIK, M. A., SMUGA-OTTO, K., ANTOSIEWICZ-BOURGET, J., FRANE, J. L., TIAN, S., NIE, J., JONSDOTTIR, G. A., RUOTTI, V., STEWART, R., SLUKVIN, I. I. and THOMSON, J. A. (2007). Induced pluripotent stem cell lines derived from human somatic cells. Science 5858: 1917-1920.

ZAMBIDIS, E. T., PARK, T. S., YU, W., TAM, A., LEVINE, M., YUAN, X., PRYZHKOVA, M. and PEAULT, B. (2008). Expression of angiotensin-converting enzyme (CD143) identifies and regulates primitive hemangioblasts derived from human pluripotent stem cells. Blood112: 3601-3614.

ZAMBIDIS, E. T., PEAULT, B., PARK, T. S., BUNZ, F. and CIVIN, C. I. (2005). Hematopoietic differentiation of human embryonic stem cells progresses through sequential hematoendothelial, primitive, and definitive stages resembling human yolk sac development. Blood106: 860-870.
ZEISIG, B. B., MILNE, T., GARCIA-CUELLAR, M. P., SCHREINER, S., MARTIN M. E., FUCHS, U., BORKHARDT, A., CHANDA, S. K., WALKER, J., SODEN, R., HESS, J. L. and SLANY, R. K. (2004). Hoxa9 and Meis1 are key targets for MLL-ENL-mediated cellular immortalization. Mol.Cell.Biol. 2: 617-628.

ZHAN, M., MILLER, C. P., PAPAYANNOPOULOU, T., STAMATOYANNOPOULOS, G. and SONG, C. Z. (2007). MicroRNA expression dynamics during murine and human erythroid differentiation. Exp. Hematol. 7: 1015-1025.

ZHANG, J., NIU, C., YE, L., HUANG, H., HE, X., TONG, W. G., ROSS, J., HAUG J., JOHNSON, T., FENG, J. Q., HARRIS, S., WIEDEMANN, L. M., MISHINA, Y. and LI, L. (2003). Identification of the haematopoietic stem cell niche and control of the niche size. Nature 6960: 836-841.

ZHOU, H., WU, S., JOO, J., ZHU, S., HAN, D., LIN, T., TRAUGER, S., BIEN, G. YAO, S. and ZHU, H. (2009). Generation of induced pluripotent stem cell using recombinant proteins. Cell Stem Cel/4: 381-384.

ZIEGLER, B. L., VALTIERI, M., PORADA, G. A., DE MARIA, R., MULLER, R., MASELlA, B., GABBIANELLI, M., CASELlA, I., PELOSI, E., BOCK, T., ZANJANI, E. D. and PESCHLE, C. (1999). KDR receptor: a key marker defining hematopoietic stem cells. Science 5433: 1553-1558.

ZWAKA, T. P. and THOMSON, J. A. (2003). Homologous recombination in human embryonic stem cells. Nat.Biotechnol. 3: 319-321. 


\section{Further Related Reading, published previously in the Int. J. Dev. Biol.}

See our recent Special Issue Placenta edited by Joan S. Hunt and Kent L. Thornburg at: http://www.ijdb.ehu.es/web/contents.php?vol=54\&issue=2-3

Feeder- and serum-free establishment and expansion of human induced pluripotent stem cells

Mehdi Totonchi, Adeleh Taei, Ali Seifinejad, Mohammadsharif Tabebordbar, Hassan Rassouli, Ali Farrokhi, Hamid Gourabi, Nasser Aghdami, Ghasem Hosseini-Salekdeh, and Hossein Baharvand

Int. J. Dev. Biol. (2010) 54: 877-886 (doi: 10.1387/ijdb.092903mt)

\section{Epiblast-derived stem cells in embryonic and adult tissues}

Maria P. De-Miguel, Francisco Arnalich-Montiel, Pilar Lopez-Iglesias, Alejandro Blazquez-Martinez and Manuel Nistal Int. J. Dev. Biol. (2009) 53: 1529-1540

Genetic and epigenetic instability of human bone marrow mesenchymal stem cells expanded in autologous serum or fetal bovine serum

John-Arne Dahl, Shivali Duggal, Neralie Coulston, Douglas Millar, John Melki, Aboulghassem Shahdadfar, Jan E. Brinchmann and Philippe Collas

Int. J. Dev. Biol. (2008) 52: 1033-1042

Developmentally regulated expression of hemoglobin subunits in avascular tissues

Fiona C. Mansergh, Susan M. Hunter, Jenny C. Geatrell, Miguel Jarrin, Kate Powell, Martin J. Evans and Michael A. Wride

Int. J. Dev. Biol. (2008) 52: 873-886

Tracing the hemangioblast during embryogenesis: developmental relationships between endothelial and hematopoietic cells

Thierry Jaffredo, Karine Bollerot, Daisuke Sugiyama, Rodolphe Gautier and Cécile Drevon

Int. J. Dev. Biol. (2005) 49: 269-277

The Nogent Institute - 50 Years of Embryology

Nicole Le Douarin

Int. J. Dev. Biol. (2005) 49: 85-103

Of birds and mice: hematopoietic stem cell development Isabelle Godin and Ana Cumano Int. J. Dev. Biol. (2005) 49: 251-257

Embryonic development of the human hematopoietic system Manuela Tavian and Bruno Péault

Int. J. Dev. Biol. (2005) 49: 243-250

Multilineage hematopoietic progenitor activity generated autonomously in the mouse yolk sac: analysis using angiogenesis-defective embryos

Christine Rampon and Philippe Huber

Int. J. Dev. Biol. (2003) 47: 273-280

Pathways in blood and vessel development revealed through zebrafish genetics Philip S Crosier, Maggie L Kalev-Zylinska, Christopher J Hall, Maria Vega C Flores, Julia A Horsfield and Kathryn E Crosier

Int. J. Dev. Biol. (2002) 46: 493-502

Embryonic stem cells and transgenic mice in the study of hematopoiesis S H Orkin

Int. J. Dev. Biol. (1998) 42: 927-934
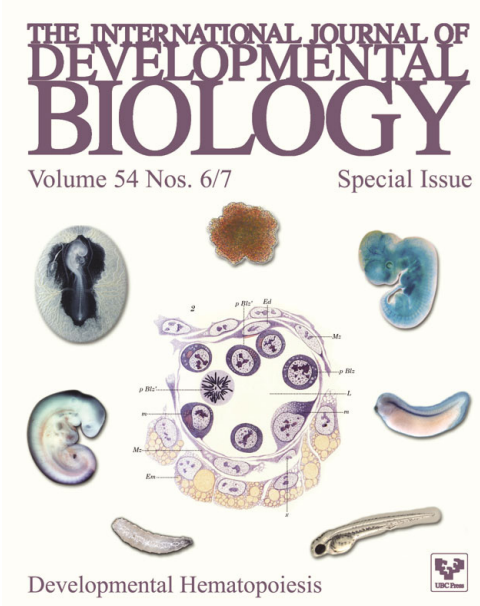

5 yr ISI Impact Factor $(2009)=3.253$

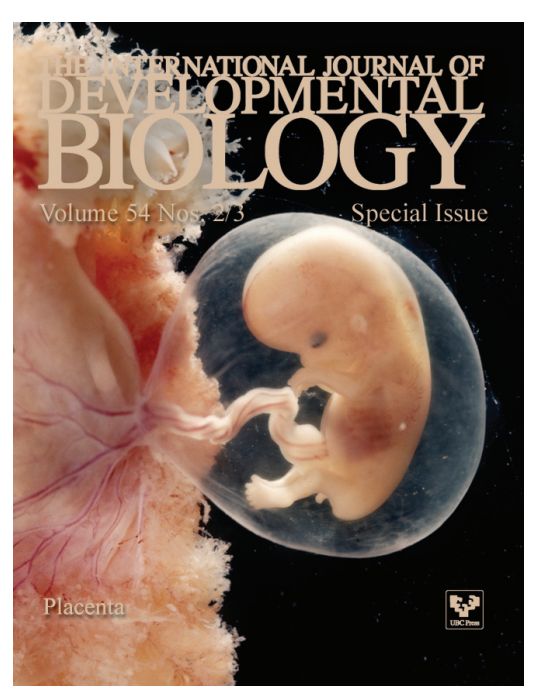

